Historic, Archive Document

Do not assume content reflects current scientific knowledge, policies, or practices. 



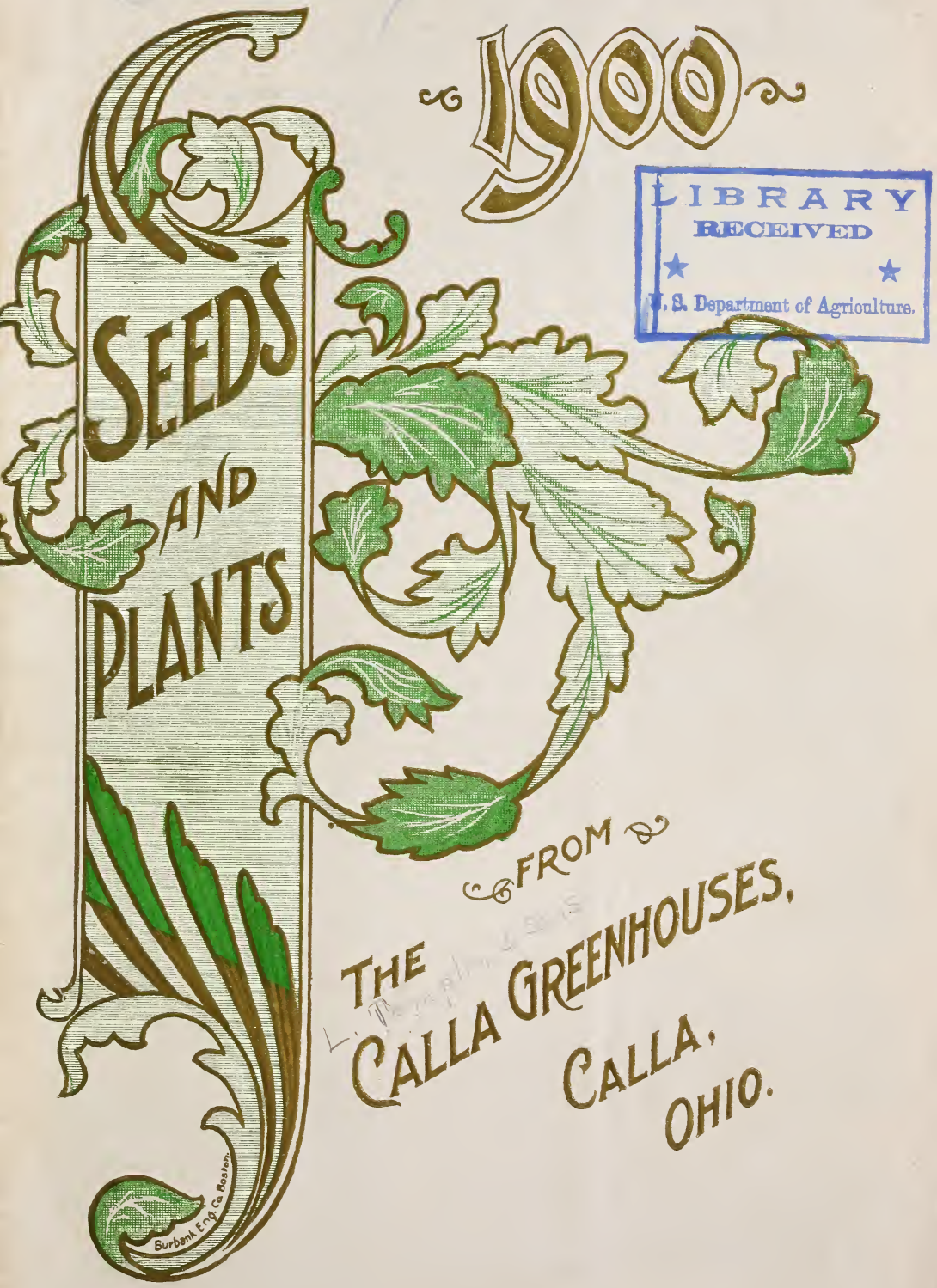




\section{$\because \mathrm{HOW}$ TO ORDE R. \\ MUCH TROUBLE, DELAY, AND DISAPPOINTMENT MAY BE AVOIDED BY OBSERVING THE FOLLOWING INSTRUCTIONS.}

YOUR NAME. We ask as a special favor that 1y as possible Most people write their orders plain enough. but when they come to sign their name and address (the most important part) they write it carelessly. It may iook plain enough to them but in many cases those not familiar with the name cannot read it. This one item alcre causes more annoyance and delay than all others combined. Again we say please write your name plainly as possible.

\section{UISE OUR ORDER SHEET. Please} enclosed order sheet as it will ensure the more correct filling of your order. Fill out all blanks, especially your name and address and state how you wish your goods sent, whether by mail or express. Write the name of only one Item on each line and mark the catalogue price in proper column opposite the name.

\section{SEED \& PLANT Orders Separate}

Keep Seed and Plant orders Separate. Our Seed and Plants are in separate departments under the supervision of different persons. It will, therefore, facilitate the filling of orders by keeping them separate. If you do not wish to order Seeds and plants at the same time tear order sheet apart and retain part for rutul use.

\section{ORDER EARLY, It would be a great ac-} of our customers would send their orders us if more fore the rush of the busy season. If, however, you should postpone ordering until seeds are wanted, you can rely on getting them promptly. Don't go to the nearest grocery store and buy old seed that you know from experience are liable to disappoint you.

CORRESPONDENCE, Do not mix your spondence together. 1f you wish to write us concerning the order, write on back of order or on separate sheet. Many mistakes are made or plants omitted from order by mixing the order and correspondence together.

\section{E OF ORDER. We cannot accept or-} less amount than 25 cents. as the trouble and expense of packing and mailing one or two plants would cost us nore than the plants are worth. This restrietion, however, does not apply to seed orders.

\section{YHEN TO ORDER. We are frequently} asked when is the best time to order plants. Our answer is when you can best care for them. IV are shipping plants almost every day throughout the year. The bulk of our trade, however, is during March, A pril, and May. Per. sons ordering seeds and plants together may have seeds forwarded at once and plants held until wanted. In such cases it is best to state when ordering that you will notify us when to send the plants.

\section{SEEDS AND PLANTS BY MAIL.}

All seeds and plants offered in this cataloguc, unless otherwise stated, will be carefully packed and forwarded by mail, postage paid by us, to any post-offlee in the United States, and guaranteed to reach you in good condition. No matter where you live whether in Maine or Florida, Oregon or Texas we will deliver them to your nearest post-office.

SEEDS BY EXPRESS. Persons order large quantities to be forwarded by ing $s$ e eds in may deduct 8 cents per pint, 15 cents per quart. and 10 cents per pound from catalogue price. Where the order is large and distance not too great, this is at ways the cheapest way to order. We do not pay Express charges.

PLANTS BY EXPPESS. Many prefer to have their by express. as we can usually send ra a size of plants and condition offset the express me do not prepay express charges. but always add liberally of choice giatis plints, which in many instunces will more than pay the charges.

SP:CIAI EXPAESS RATES.

All express companies now carry se $-d$ s and plants at a reduction of 20 per cent. from resular merchardise rates.

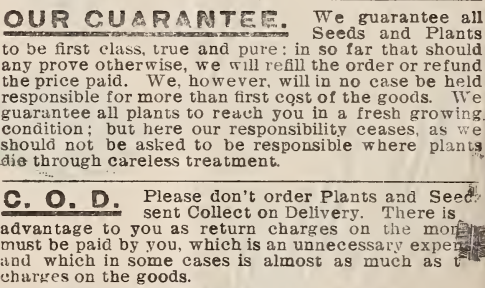

\section{TERTEST.}

RE IAITTANCES. All orders must be accompanied with cash. We keep no book account with our customers, and will in no case tll orders where there are no remittance.

HOW TO SEF D MONFY. All money should be sent by Post-Office Money Order. Bank Draft, above ways it is at our risk. but if sent in an ordinary letter we will not be responsible in case of loss. We consider Postal Money Order the safest and most convenient, and the cost is so triling.

STAMPS. Please don't send Postage Stamps, as they so frequently become damp in transit and Stick together causing much annoyance and frequently the entiredestruction of the stamps. ADDrass,

L. Templin \& Sons, Calla, Ohio.

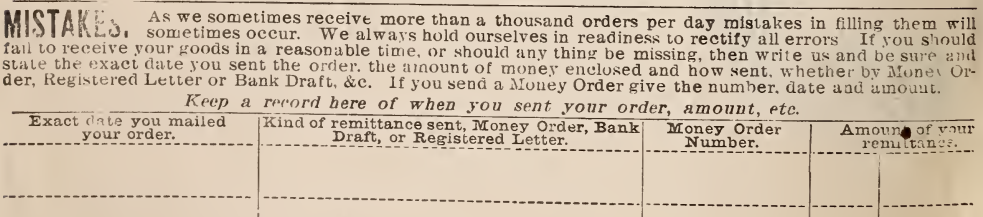




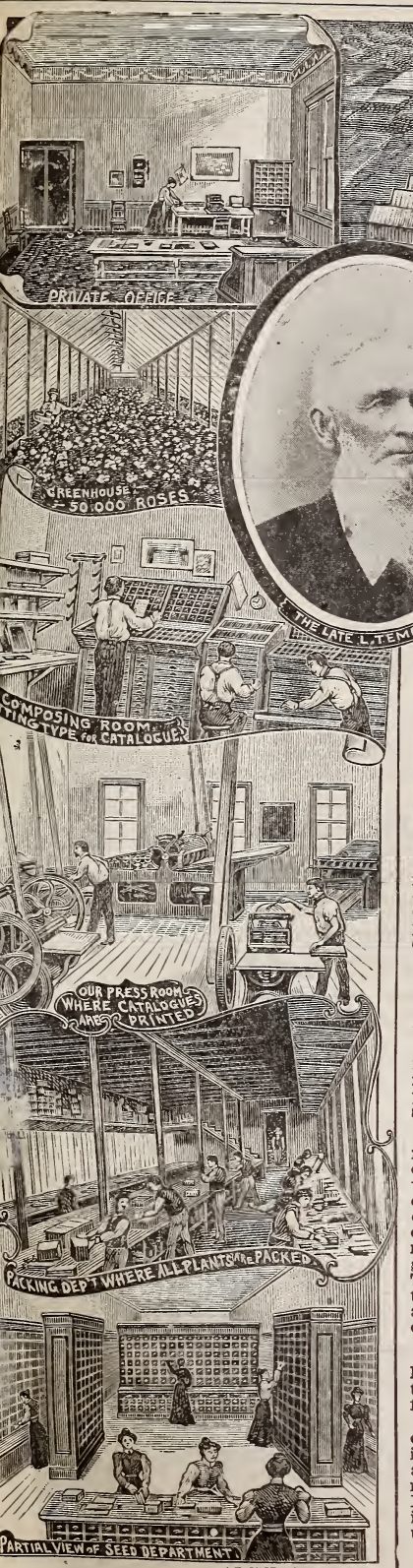

In honor to his name his sons will continue the business In honor to his name his sons will
without any change in the firm name. 


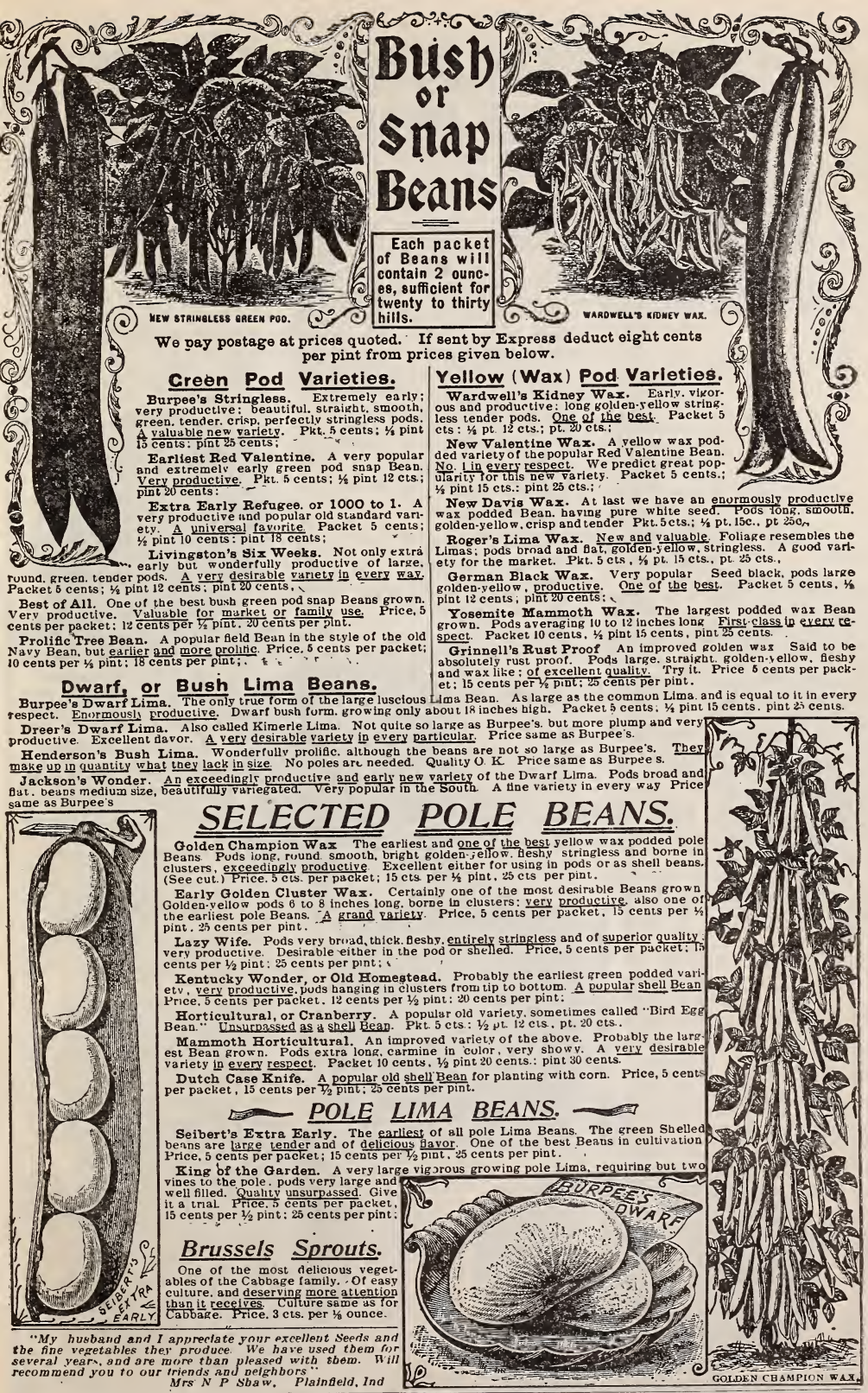

Your Friends will appreciate a copy of our Catalogue. Send us their names and addresses. 


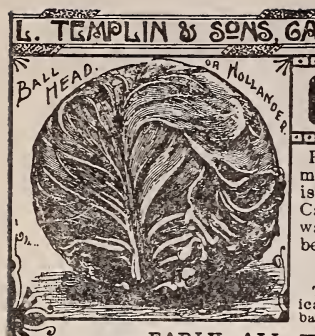

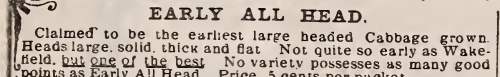

TRUE EARLY JERSEY WAKEFIELD.

This varlety is unquestionably the best early Cabbage prown. Heads mediun large. con. cal and very solid, shurt stem. The The are earlier varle ties. but if you want an early Cab-
bage, certaln to produce good. iarke, solid heads, plant Wakeleld. Packet 3 cents.

EXTRA EARLY EXPRESS. points as Early All Head. No variety possesses us many good beads. very early, but nut so solici as Warefeld. A very de.

VANDERGAW OR ALL SEASON.

Orlyinated $b_{\nabla} M r$ Vardergaw. a Cabbake specialist of Long Island. A Iso sent out medlum early as well as tall and wipter use, Beads very large, thick, solid and fat. 3c.

HENDERSON'S EARLY SUMMER. A deservedly popular second early varlety forming large. solid. Alattened heads of ex
cellent quality. Fully dudile the sze of Waketleld. Packet 3 cents.

EARLY WINNINGSTADT.

A popular medium early varlety. formlng conlcal heads AD excellent second early NEWART EARLY FLAT DUTCH.

A deslrable second early variety. Hesds medium to large. In the strle of the popular old Flat Dutch. A flist-class tariety in every respect. Packet 2 cents.

\section{LARGE EARLY YORK.}

A popular old vartety Stlll a great favorite with many, partlcularly th the South EARLY ETAMPES,

The earllest variety we offer except Express Heaos are nblonk. rounded at the top. very solid and $\frac{\mathrm{Hrm}}{\mathrm{It}} \mathrm{It}$ une quality Price. 2 cents per packet.

EARLY VARIETIES MIXED.

An equal mixture of all the above varietles when only one pucket or Early Cabbage seed is wanted. w

\section{CHOOCE LATE CABBAGE}

WORLD BEATER, OR AUTUMN KING.

Thls grand late $C$ abbage has been.sent out under differ. ent names. but it matters little what name you give it

you are ce rtain you bave it, as it
is unguestionubly one of our best
winter varteties. Heads unusually bruad, thick and sulld. Pkt

TEE NEW LUPTON Originated on Long Island by a Mr Lupton who says: In this secured the perfection of wve and rellabilit. of of beading which a re the must viluable features
of a Cabbage " Heads are quite large. lat and thick Mr. Brill writes us: "By all means cata. logue the Lupton. Last season and Lupton. and we had the fnest Cabbage we ever grew Ptice, 5 cents per pkt.: is cents perounce. 45 cents per $1 / 4$ pound:
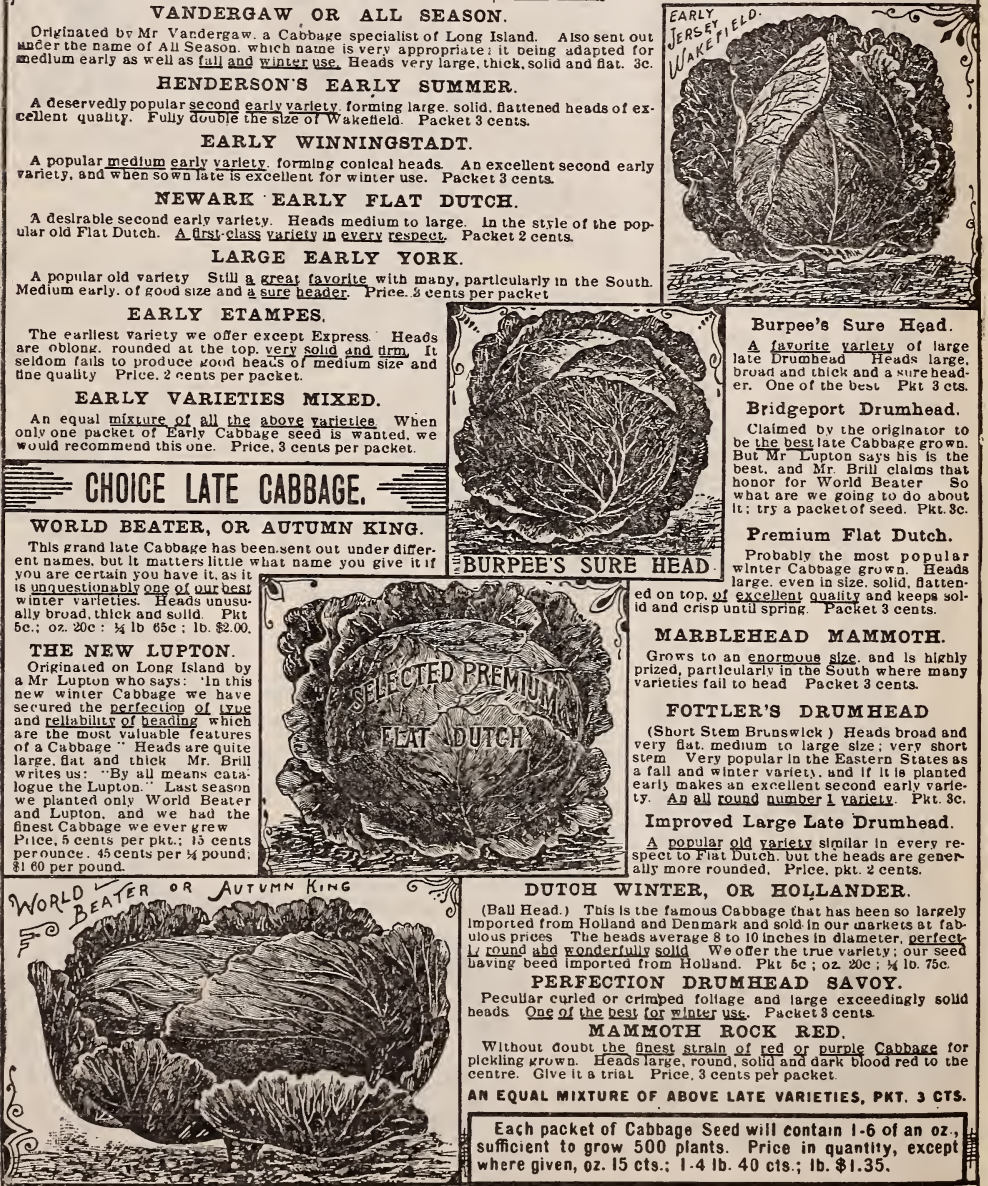

Burpee's Sure Head. A tavurite yarlety of large bruad and chick and a kire head-

Bridgeport Drumhead. Claimed by the originator to be the best late Cabbage grown. But honor for World Beater So what are we going to do about . trs a packet of seed. Pkt. 3 .

Premium Flat Dutch. Probably the most popular winter Cabbage gruw n. Heads id and crisp until spring.

MARBLEEEAD MAMMOTH. Grows to an enormuus slze. and is highly prized, partlculariy in the Suuth where many

FOTTLER'S DRUMHEAD

(Shurt Stem Brunswlek) Heads broad and very fat. medium to large size: very short tem Very popular ln the Eastern Siates as fall and winter variets, und if it is planted y. AD Qll round number 1 variely. Pkt. 3c. Improved Large Late Drumbead. A popular old variety similar in every respect to Fiat Dutch. Uut the heads are gener DOTOB WINTER, OR HOLLANDER.

(Ball Head.) This is the famous Cabbage that has been so largely mported from Holland and Denmark and sold In our unarkets at fab. ulous prices The beads average 8 to 10 inches in dlameter, perfect Laving beed imported from Holland. Pkt $5 \mathrm{c} ; 02,20 \mathrm{c} ; 410.75 \mathrm{c}$. PERFECTION DRUMHEAD SAVOY.

Pecullar curled or crimped follage and large exceedingly solld heads One of the best for plnter ust. Packet 3 cents. MAMMOTH ROCK RED. Whthout coubt the finest straln
plckling krown. Headstarke, round, solid and dark blood red to the centre. Glve it a trisl Price, 3 cents per packet.

AN EQUAL MIXTURE OF ABOVE LATE VARIETIES, PKT. 3 ctS.

Each packet of Cabbage Seed will contain 1.6 of an oz., sufficient to grow 500 plants. Price in quantity, except where given, $02.15 \mathrm{cts}$; $1.4 \mathrm{lb}$. $40 \mathrm{cts}$; $\mathrm{Ib}$. $\$ 1.35$. 


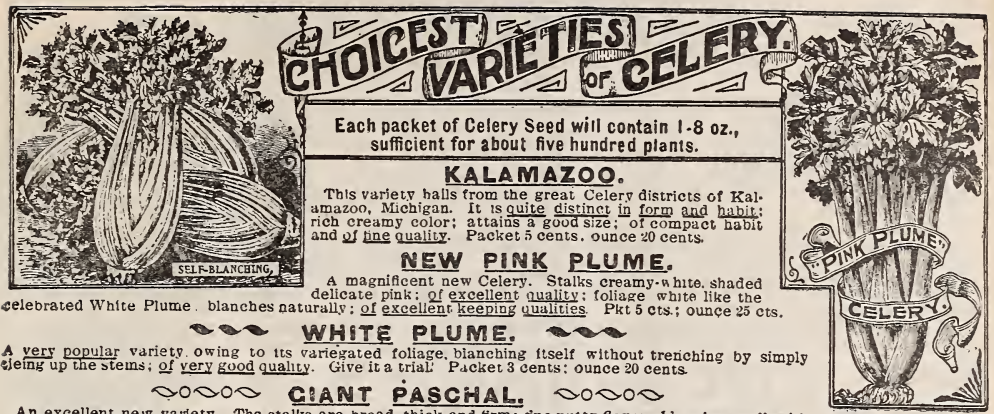

An excellent new vartety The stalks are broad, thick and tirm: tine nutty favor; blanches well with

OLDN SELF

A most excellent rarfety that cunnot be too highly recommended The heart is large. solid and of a rich golden-vellow color ;

foliage light yellow. blanching nlcely with but little billing up. Unsurpassed in appearance and quality Pkt $5 \mathrm{cts}$; oz. $25 \mathrm{cts}$

Perfection Zartwell. No variety equals this in keeping New Rose. This variety is very ornamental on the table. \begin{tabular}{l|l} 
Qualites, and few surpass it in Uavor A general favorite among & $\begin{array}{l}\text { The beautiful tracings of delicate pink shadings with the white } \\
\text { in the blanched stalk and beart: }\end{array}$ gardeoers. Price, 2 cents per packet, 15 cents per ounce.
\end{tabular}

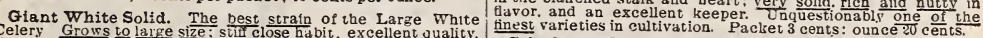
Celery Grows to large size: siffi close habit. excellent quality. $\frac{\text { inest varieties in cultivation. Paclset } 3 \text { cents: ounce } 20 \text { cents. }}{\text { Celeriac, or Turnip Rooted Celery. Grown exclusively for }}$ Giant Golden Heart. An Improved strain of the Gulden $\begin{aligned} & \text { its ruots which are turnip-shaped, very smooth. tender and } \\ & \text { marrow-like. The roots aie cooked and slic }-d \text {. When }\end{aligned}$

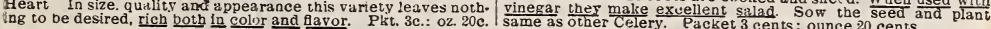
PSELECTED SWEET CORN. ?

A valuable variety introduced by A C Kendal. of Cleveland. who clalms it to be the largest and most productive early $S$ weet Corn grown. Ears 8 to 10 inches in length, having 10 to $\frac{1}{8 \text { rows }}$ on each cob. Kernels pure white and very siveet. We were highly pleased with it last season. First of All. Probably the earliest variets grown. It is a sport trom Cory which it closely re. Early Cory. This has always been considered the earliest of all. Will produce earliness. the table in 50 days from planting. Of dwarf nabit, medium ears, large broad kerneis. Excellent. Early Champion. A valuable new early large growing variety. onls a few days later than the omall eared sorts. and producing 12 rowed ears 8 to 10 inches long. White kernels and rery sweet. Honey Sweet. Origlnated with a German in Pa.. Who has the reputation of bringing the best corn to market. The husks and stalks are of a red color while growing. while the corn itself is a creamy white; medium early, sweet and verp productive. Give it a trial

Country Gentleman. (Shoe peg.) Probably the tinest flavored corn grown. Very productlve, medium early in sedson, ears of immense size kernels pure whice. very deep and placed ir-

Clark's None Such. A large eared second early productlye varietg. Ears large und produces $t$ wo or more on each stalk; fodder plnk: kernels murbie white. Verf attractive tender and
swees. For market gardeners or the family garden it has no superior. Stowell's Evergieen. More largely grown than any other variety, belng the general favor. t te for main crop: also among cinners anc mant deep. tender and ine favorea. remaining a lon time in edible condition. You will make no mistake py planting this variety.

Price, 5 cents for large two ounce packet, sufficlent for abjut 50 hills; 20 cts. per pt.; 35 cts. per qt.

\section{- SELECTED POP CORN}

New Red Beauty. A valuable new Rice Pop Corn, intro-

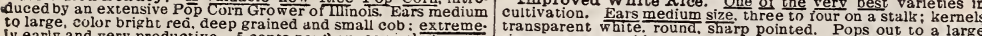
ly early and very productive. 5 cents per 2 ounce packet.

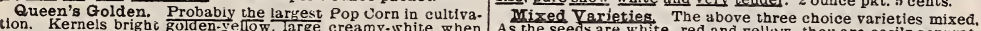

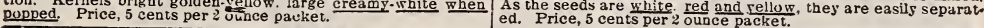

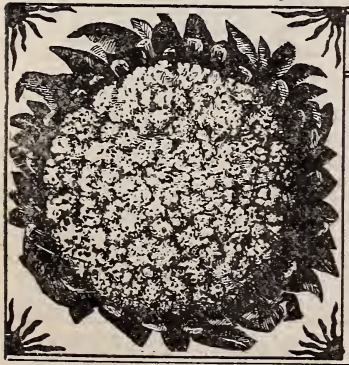

\section{SELECT CAULIFLOWER.}

Caulifower requires the same general treatment as Cabbage. It succeeds best, however, in a deep, rich. moist soil, and should be watered freely in dry weather.

\section{IMPROVED SNOWBALL.}

This is now the most popular variety of Caulifower grown. We used to think it impossible to grow good caulifower, but since the introduction of Snowball we fnd it no more trouble to grow nice heads of Caulifiower than Cabbsge. It is of dwarf habit, quite early and sure to head. We guarantee our seeds equal to any on the market, Price, packet or 200 seeds, 15 cents; $1 / 4$ ounce 75 cents; ounce $\$ 2.75$.

\section{\# EXTRA EARLY PARIS. E}

One of the earliest and most popular varieties in the Parls Markets. Probably the brice, packet of 200 seeds, 5 cents; 14 ounce 20 cents; ounce 60 cents.
Prood quality. - * VEITCH'S AUTUMN CIANT.*

A large robust growing late parlety: hesds large, compact and well protected by
he leaves. Very popular in the South 


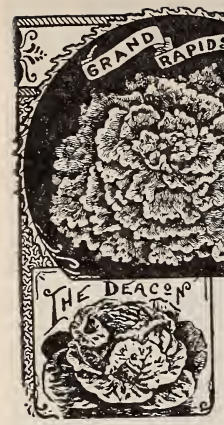

and has thick, savory. curled leaves, remaining fit for use

strone grower light areen. beautifully curled leaves, crisp and tender Probably equally viluable for the garden. Price, 5 cents per packet.

\section{$\Rightarrow$ \%RIANON, OR CELERY. QEE}

A tavorite variety oi Lettuce in Europe. The long. narrow teaves form solda. ublong heacis like Waketield Cabbage, bleaching snow-white it excels all others in crispness HENDERSON'S NEW YORK LETTUCE.

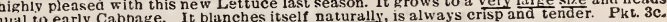

- o SILVER BALL. OO-

with handsomely curled leaves The head is of an attractive. A verv solid and compact variety with handsomely curled leaves. The head is of an atractive. silvery-white color. very rich. buttery, and of most delicious thyor. It is an excel
cool spring and fall months. A very desirable variety. Price. 3 cents per packet.

\section{TILTON'S WHITE STAR.}

IMPROVED HANSON.

TOMHANNOCK.

One of the best known and probably the best heading varie- $\quad$ Fine curled toliage, of a redatish brown color. of excellent

che Cos varieties. Light green curled leaves. crisp and tender. 3. of September. Always free
CREEN FRINCED, OR CALIFORNIA CURLED.

\section{A valuab} edges fringed. Much used for garnishing and also as a salad. Ver, desirable. Price. 3 cents per packet. Denver Market. Highly recomimended. A Denver gardener claims that in a test of ninety-six varte.

Big Boston. A mammoth strain of the Boston Market Lettuce. Much larger and b

parent variety. Curled foliage, forming heads of excellent quallts. Price, 3 cents per pk

White Paris Cos. The heads are long, upright, with long leaves. It is very hard
of large size, and long in running to seed : brittle and highly Havored Fine. Pkt. 3c.

All The Year'Round. A popular variety; compact, crisp and tender, r
ts qualities for a long time. A first-clasg all purpose variety. Pkt. 2 cents.

ts qualities for a long time. An of the most popular varieties for venaral us

Early, tender and slow to seed; of superior quality. Packet 2 cents.

Golden Head. A splendid variety of Cabbage Lettuce, forming compact. crisp, golden-yellow heads. A very satisfactory variety. Pkt. 2 cents

The Deacon. A magnificent butter bead Let tuce. producing large heads of superior quality : light green outside and cr.

Passion. Grows to large size with tenPassion. Grows to large der golden-yellow heart, outerlea ves slightis it matures nicely for spring shipment. Price, 3 cents per packet.

Mixed Lettuce. An equal mixture of Mixed
alr the above varieties. Packet 2 cents.

\section{消 DANDELION.}

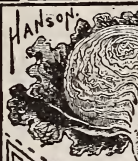

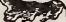

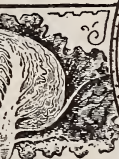

की

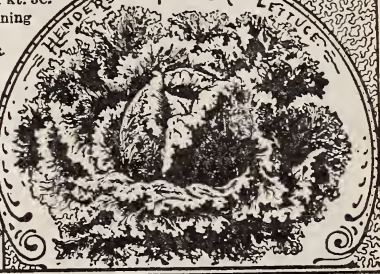

\section{HORSE RADISH.}

Plant roots in May, small end down. with the top an inch or so below the surface in rich. cultivated soil. Will form roots of large size in one season. 6 roots 15 cents: 12 for 25 cents.

\section{KALE, Or BOREOCOLE.}

Dwarf Scotch Curled. Of all the Caboage family this is the most tender and delicious. Should be more universally grown. frost. Price. 5 cents per one-eighth ounce packet.

\section{$\equiv$ KOHL RABI. $\equiv$}

Early White Vienna. A vegetable between the Cabbage und Turnip. Forms large bulbs on stems above the ground. Cook while young and tender. Packet 5 cents.

\section{$\rightarrow$ LEEK. W.}

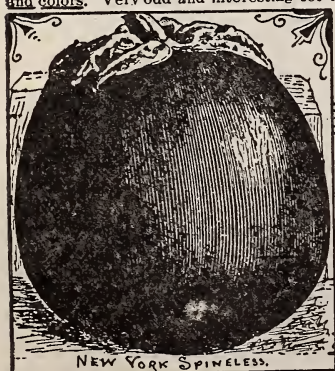

a Broad Scotch, or London Flag. Especially desirable for by the should be grown in Macket 3 cents.
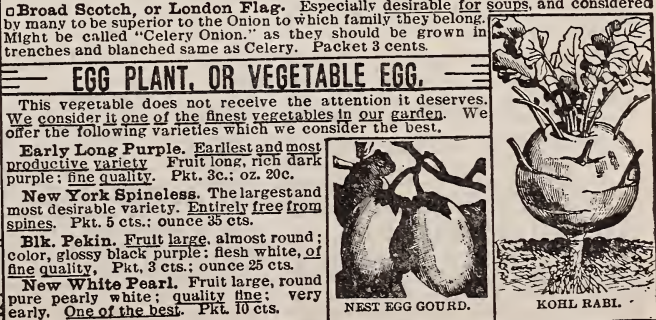


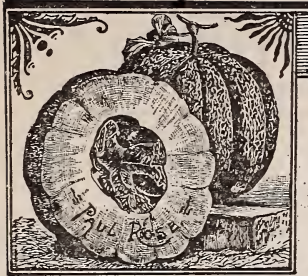

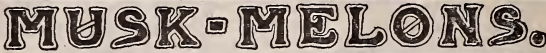

NEW MUSK MELON, PAUL ROSE.

This new Melon probably combines more good qualities than any other variety. I was originated by Mr. Paul Rose, a successful Melon grower. It.is a cross between the Osage and Netted Gem. In the Chicago market it always brings the highest price, and in the time of glut the "Paul Rose" was eagerally called for. In size they average about tive inches in diameter and welgh about one and a half pounds. Flesh quite thick, something fine. Packet 5 cts.; ounce 15 cts.; 1.4 pound 35 cts.; pound 75 cts.

\section{NEW COLDEN EACLE MUSK MELON.}

A rrand new Melon. Oblong in shape, about ten inches long and seven inches in diam eter; well ribbed. heavily netted : coior, golden-yellow Flesh rich salmon, very swee and melting. Especially recommended as a general purpose Melon. Price, packet 5 cents; ounce 15 conts; pound 75 cents.

EXTRA EARLY GRAND RAPIDS. The earliest Musk Melon grown. Large. handsome, attractive fruit. Flesh bright saimon. of fine quality. The strongest point other varieties. Packet 5 conts.

\section{NEW KINSMAN QUEEN.}

Originuted with Mr. F. Banning of Kinsman, Ohio, We give tis description: "Ten days earlier than the earliest Melon we have ever tested. Three times as harge as Emeratd Gem; nearl round in shape : color, yellowish green: slightly ribbed and nettive." Pkt. 5 cts.; 02. 15 cts.; 1-4 1b. 35 cts.; 1 b. \$1,00.

Tip Top. Of uniform size and tine appearance. Flesh salmon, very juicy, sweet and tine flavored. Highly recommended. 3c. The Banquet. A yrand Melın. Perfectly free from ribs: of Golden Netted Gem. A popular old variety of medium size. Vers pruductive. Thicklv netted: tlesh green and very sweet. Largely grown fior market. Packet 3 cents.

Prolific Nutmeg. A popular rariety. Flesh thick, green, excellent quality. Fruit meóium, round und Leavily netted. A Jersey Belle. This new Melon is one of the largest of the E.jesh green, quality excellent. Packet 3 cents.

Miller's Cream, or Osage. One of the most popular Melons grown. Large, oval. slightly ribbed and thickly netted. Flesh deep salmon. excellent quality. Uniformly large and hea
A number one variety in every respect Packet 3 cents.
New Musk Melon, ROCKY FORD.

Claimed to be an improved strain of the poputar Netted Gem Some what larger in size and mure oval in form. Flesh green very early and prolite. This. We believe. is destined
one of the most popular varieties. Packet 5 cents.

\section{HENDERSON'S NEWPORT.}

The Newport is a very early Melon. Fruit round with shallow ribs. Uolor. dull green, changing to golden-yellow. Flesh very thick, color green: of excellent davur. rich and
ium size and very productive Packet 5 cents.

Emerald Gem. Small in size, perfectly round and smooth. Skin emerald green when ripe: Gesh reddish salmon, very juicy exceedingly sweet. Packet 3 cents.

Champion Market. A very popular market varlecy Large size. deeply ribbed. Fiesh green and very sweet. Early and productive. None better. Packet 3 cents.

Columbia. Another grand new Melon. Very large size. skin smouth withuut ribs. Color, light buff, flesh green. solid weet and melting. Packet 5 cents.

New Melrose. A very desirable new Melon introduced by Mr. Burpee. It is very hardy, vigorous and productive; oval in shape : dark green, densely netted and with
equal to the best. Try it Packet 3 cents.

Banana. Distinct from all others. Grows 12 to 15 inches ong and 2 to 3 inches in diameter. Flesh rich saimon and of exellen quality. Resembles a Banana. Packet 3 cents.

Mixed Varieties. All of the above varieties mixed. If you wish unly one packet. this is the one. Packet 3 cents.

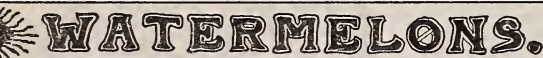

\section{DQ WONDERFUL SUGAR. DO}

Prof. Massey, of Raleigh N. C. says: "I have urown nearly ever; Melon advertised in the catalogue. old and new, and can sincerelv say that this Melon is the best of all and leaves nothine to be desired in a Water Melon. The vines ure vigor ous. Melons uniformly large. oblong in form, some reaching two feet in length and ten to twelve inches in diameter. Skin stifiea white and green; flesh pale pink. crisp ant sweet. Solid hearts free from any cracks green;
or open places. Packet 5 conts; ounce 10 cents.

\section{DUKE JONES.}

This new variety certainly deserves attention. It is nedrly round. of enormous size, mottlea light and dar'k green: quality unsurpassed and an excellent shipper. Here is what they say of it: "Mr. Gin ancean has shipped ten car loid 43 pounds. They were the finest Melons I ever saw, and quality fine.

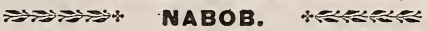

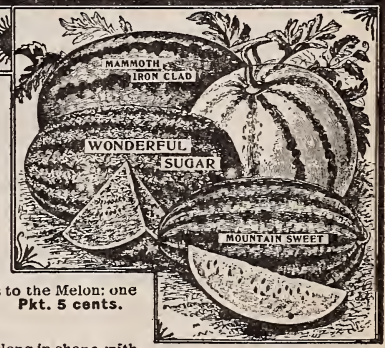

A very large, solid, heavy Melon of splendid

little depression at the botiom end. Color, dark green, pecul- Seminole. Very earls and prolific. Oblong. of large size. larly mottled with light green sputs. Weighs 25 to 40 pounds. Flesh deep searlet, Sweet and luscious: medium early. An exMelon certainly has more than ordinary merits. 5c.; oz. 10c.

New Sweet Heart. An entirely distinct new varlety. It is early, large, handsome, heavy, a good keeper and is creating much attention wherever grown. Vine is vigorous and dark green. Rind thin, fesh bright red. sold but very tender. melting, and sweet. Don't fail to include this variety-in your order. Packet 3 cents.

The Dixie. A cross between Kolb's Gem and Mountain Sweet. Quite early. Of unifurm large size. Gesh deep scarlet. very fine grained and sweet. Very productive Packet 3 conts.

The Dela ware. Of oblong sfiape, very thick through. Skin (autifully striped: flesh brilliant and fine quality Pkt. 3 cts. Víck's Extra Early. Oblong, smooth, rather small. flesh same vine, flesh gright red Very sweet Packet 3 cents. Hungarian Honey. Of medium size, round as a ball :.eolor dark green. Very early. Flesh bright red. One of the sweetest melons we grow : seeds very small. Packet 3 cents.

Mammoth Ironclad. Of mammoth size oblong in form, handsomely marked. Alesh bright red and very solid: rind thin nd hard. Early and a guod keeper. Packet 3 cents.

Kolb's Gem. This is the variety so largely grown in the Soutb for the Northern markets Packet 3 cents.

Mountain Sweet. Early, large, oblung. Dark green color: Vancluse. A. promising new French variety, Oblong, daris green, eariy and of large size: flesh brizht crimson, very sweet; in rind, seeds bright red. Packet 3 cents.

Colorado Preserving Citron. Grown for sweet meats, preserves, etc. Flesh very solid. makes clear, transparent pre: bright pink, solid and sweet. One of the earliest. Pkt. 3 cts. serves; of fine flavor. Packet 5 conts.

Each packet of our Melon Seed will contain 1-4 ounce, sufficient for about 20 hills. Price of melon Seed in quantity. except where noted, 10 cents per ounce packet; 20 cents per $1-4$ pound; 50 cents per pound, by mail, postpaid.

THE "GALLA" SPRAY PUMP. Is just what you need to kill the worms on your cabbage and cauliflower: in fact for applying the different kinds of in a Spray Pump is a necessity in every conservatory, garden, orchard, or vineyard We have carefully examined the different Spray Pumps now for spiaving poultry houses, washing windows, buggies, ete. according to our own instructions and for our exclusive traie. We believe this Spray Pump vembra special pump made features than any pump on the market. It possesses the following valuable features: It has all brass working parts. It is duuble acting. It has the largest and most perfect-air chamber. It has adjustable bucket clamp and foot rest. It has clamp for holding bucket bail. It has an agitator. It has four feet of best hose and celebrated Bordeaux Nozzle. It is clamp and neat. It is easy to work. It is easy. to buy. Price, \$3.50. See full descrlption elsewhere. 


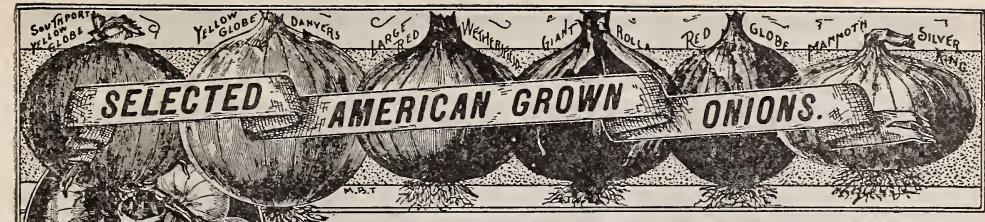

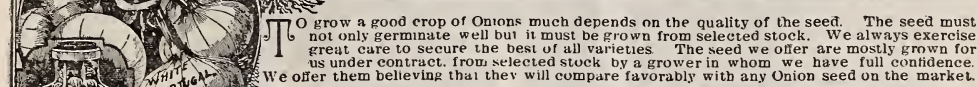

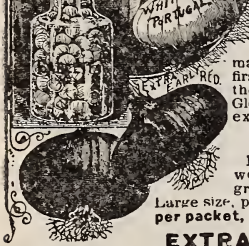

EXTRA EARLY RED. This variety matures very early It Jields abundiantly and is very close grained. solid and heavy This variety will often pro duce a good crop in cool, heavy soils where other varieties fail. It is particularly recommended for the North and Nort.h.we

YELLOW STRASBURC, OT DUTCH. One of the oldest varieties in cultivation. and can al ways be depender on for a crop. Bulbs quite lat of good size' skin yeliow: Alesh white of mild flavor and an excellent keeper This ounce 8 cents: $1-4$ pound 25 cents; pound 90 cents.

SILVERSKIN, OF WHITE PORTUCAL. Very desirable for fumily use. Flavor mild and pleasant. Skin silvery white and of handsome uppearance Hishly esteemed for pickling when young, also for market in early winter

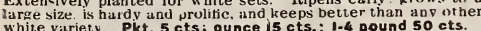
NEW MAMMOTH VICTORIA ONION. Anew race of Onions of nandsume globe shape. slightly pointed or elongated Sometimes w eightag $1 \frac{1}{2}$ to 2 pounds each un cler good cultivation the first year from seed Skin very dark. cinied. flavor mild and sweet. Pkt, 5 cts.; ounce 15 cts

EARLY YELLOW CRACKER ONION. We offer an extra tine stock of the true early Cracker Onion which is undoubtedly the earliest of all yellow Onions It has ed it is an excellent keeper probably surpassing all others in this Pkt. 3 cts.; ounce $10 \mathrm{cts}$. 1.4 pound $35 \mathrm{cts}$.

\section{TRUE GLOBE SHAPED ONIONS.}

The Southport Globe Onions are probably the handsomest Onion grown, always bringing the highest market prices

Southport White Globe. A true globe shaped Onion The skin is pure white: flesh tirm. fine grained and of mild flavor
An excellent keeper. This is unquestionably one of the band An excellent keeper. This is unquestionably one of the hand
somest Onions grown Of large size and pertect shape. al ways commanding the highest market prices Packet 5 cents; $\mathbf{0 z}$. 20 cents: $1-4$ pound 75 cents.

Southport Yellow Globe. Like the White Globe Onion ex. cept in color of the skin It is a more perfectly frlobe shaped Onion than the Globe Danvers, but not quite so early in matur-
ing. This variety is a very heavy cropper and claimed to be an

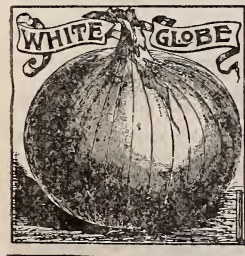

appearance and of large size $1-4$ pound 50 cts, , Ib. \$1, 75 .

Large Red Globe With the exception perhaps of some no Onion that realize such hieh prices as this. Its perfect globe color makes it extremely de. sirable. It is a good keeper and of excellent quality it. however. requires a long season to mmend it for the extreme North. Packet 5 cents; 02 is cents; i.
pound SI.75.
MAMMOTH SILVER KING.

One of the largest and most attractive of all Onions. Sinple specimens frequently attaining $21 / 9$ to 4 pounds in welght of
handsome. silvery white appearance. and excels all others in handsome. silvery white appearance. and excels all others in
mildness is bavor Always commanding the highest prices Pkt. 5 cts., ounce $15 \mathrm{cts}$.; 1-4 pound 50 cts.; pound $\$ 1.90$.

\section{TRUE PRIZETAKER ONION.}

First introduced in 1888 This magnificent yellow Onion has steadily increased in popularity. and is nom claimed by many to

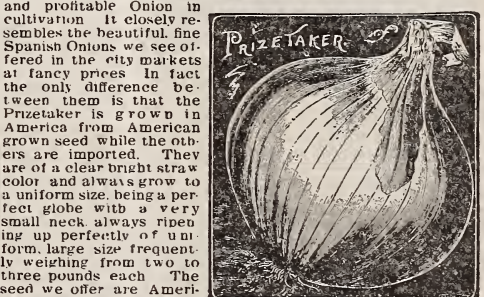
can trown being far super ior to impurted seed When American grown seed are planted $t$ is a sure cropper yielding immense crops that will find a ready market at fancv prices. It is verr harry and a good winter
keeper Pkt. 5 cts.: 02. 15 cts.: 1.416 . 50 cts, lbost, 75,

\section{NEW EXTRA EARLY BARLETTA.} The earliest Onion in cultivation They a re of a pure paper one and a half inches in diameter A r. maturity the tops die down directly to the bulbs, leaving the neatest and handsomest little Onion imaginable Largelv yrown for pickling for which purpose thev are unequalled packet 5 cents: ounce is cents:
1-4 pound 50 cents: pound $\$ 2.00$.

CHANT RED ROCCA.

A well known Italian Onion of very delicate, mild flavor, imIt size handsume globular form and light reddish brown colensivel valuable for both autumn and spring sowing. Quite ex rops. sinule bulbs frequently weighing 1 in $11 / 2$ pounds each. A

PERENNIAL TREE ONION.

This variety never forms a large bulb Tiev are splenäialy adapted for producing green Onions for early spring or fall. year Seis only pint is cts.; quart 25 cts.. postpaid.
year

\section{WHITE MULTIPLIER ONION.}

Pure silvery white. enormonsly productive frequently produc ing as many as $t$ wenty bulbs from one bulo planted of excllent Onions Sets only Pint 20 cts.; quart 35 cts., postpaid. TAIN A OUARTER OF AN OUNCE. 


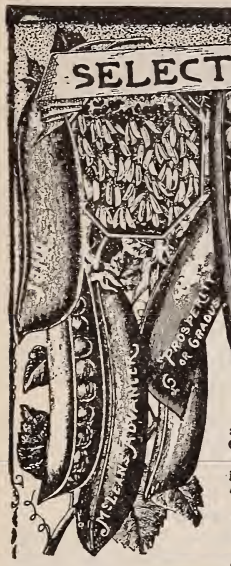

ED NORTMERN GOWN PEAS.

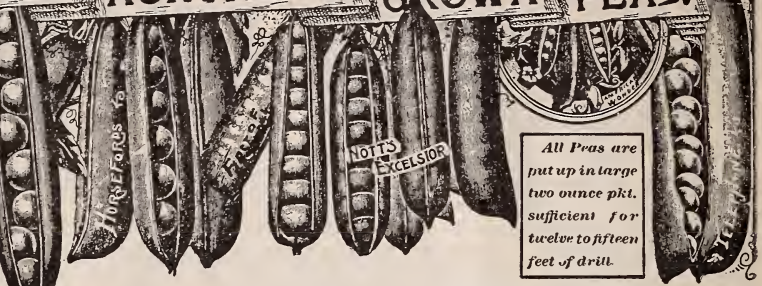

EXTRA EARLY YARIETTES.

American Wonder. Of dwarf but robust habit, growing frow 9 to 12 inches ulgh. and producing An tilled pisds, each emtainin sing One of the besi early rarieties in cultivation. Packet 5 cents; pint 20 cents; peck $\$ 1.30$

Extra Early Premiam Gem. A verv bie extra earls dwarl 1 ea uf Litle Gerr type ov wheb pords and more productive One of the best parly $d$ warf wrinkled Peas fur market and family use Packet 5 cents; pint 20 cents; peck \$1.20.

Nott's Excelsior. A grand new earlv dwart wrinkled Pea. Not quite su early as American Wonder. but growing taller. nore rubust and prolitic. each pod containing from 6 t, 8 very large neas

Alaska. Without doubt the earliest and best smunth blue Pea. Grows ubisut two feet high ang is very productive. Peas medium size, dark olut and excellent qualitg. Pkt. 5c.; pt. 15c., pk. 90c.

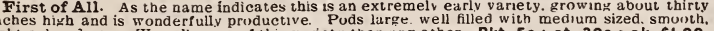
ight colured peas. We sell more of this variety than any other Pkt. 5c; pt. 20c.; pk. \$1.00. Chelsea. This extra early Pea grows fifteen to eighteen inches high and is of compact. short jointed habit. requiring no brushing. The pods are handsocie. mucb larger than other dwari varieties and gracefully curved The pods are well hilled containing elight to ten goon
sized peas of tine quality being rieh, sugary and of marrow-like flavor Certainly a vers desirable variety. Packet 5 cents; pint 25 cents; peck \$1.25.

\section{潦 MEDIUM, Or SECOND EARLY VARIETIES.}

Me Lean's Advancer, or Dwarf Champion. A very desirable second early vadít, at. taining a height of about thirty inches. A tavorite among markec gardeners. as it produces large green wrinkled peas in great abundance Those who object to the oll Champion of Eny et; 20 cents per pint; $\$ 1.00$ per peck.

Fillbasket. This variety is one of the best second early Peas in cultivation. It attains a neight of about three and ithalf feet and is a wonderfully heavy cropper The pods are larve and well tilled with large. green peas of excellent quality Pkt, 5 c.; pt. 20c.; pk. \$1.10.

Horseford's Market Garden. A grand wrinkled variety. growing about two feet high It is a prolific bearer. having vielded more shelled peus to the acre than any other variety The pods. although of medium size, are numernus and literill packed wit
Price, 5 cents per packet; 20 cents per pint; $\$ 1.25$ per peck.

Heroine. This grand new medium early wrinkled Pea grows uniformly about thirty inches high Puds very large and heavy and containıng $\alpha$ to 10 large peas of excellent quality. It is a more goud Qualities. Price, 5 cents per packet ; 20 cents per pint; \$1.25 per peck.

Abundance. A val dable second early variecy growing 18 to 24 inches hieh. sending out a half dozen or more branches from the gruund. each one very heavilv latend with long pods,
containing large wrinkled peas of delicious lavor. Pkt. $5 \mathrm{cts}$; pt. $20 \mathrm{cts}$; pk. $\$ 1.00$.

Everbearing. The vines of this excellent variety attain a height of $t$ wenty-four to thiriy inches and the pods three to four inches in lenyth The peas are ver'y larke and unsurpassed by superior if equal Packet 5 cents; pint 20 cents, peck \$1.20.
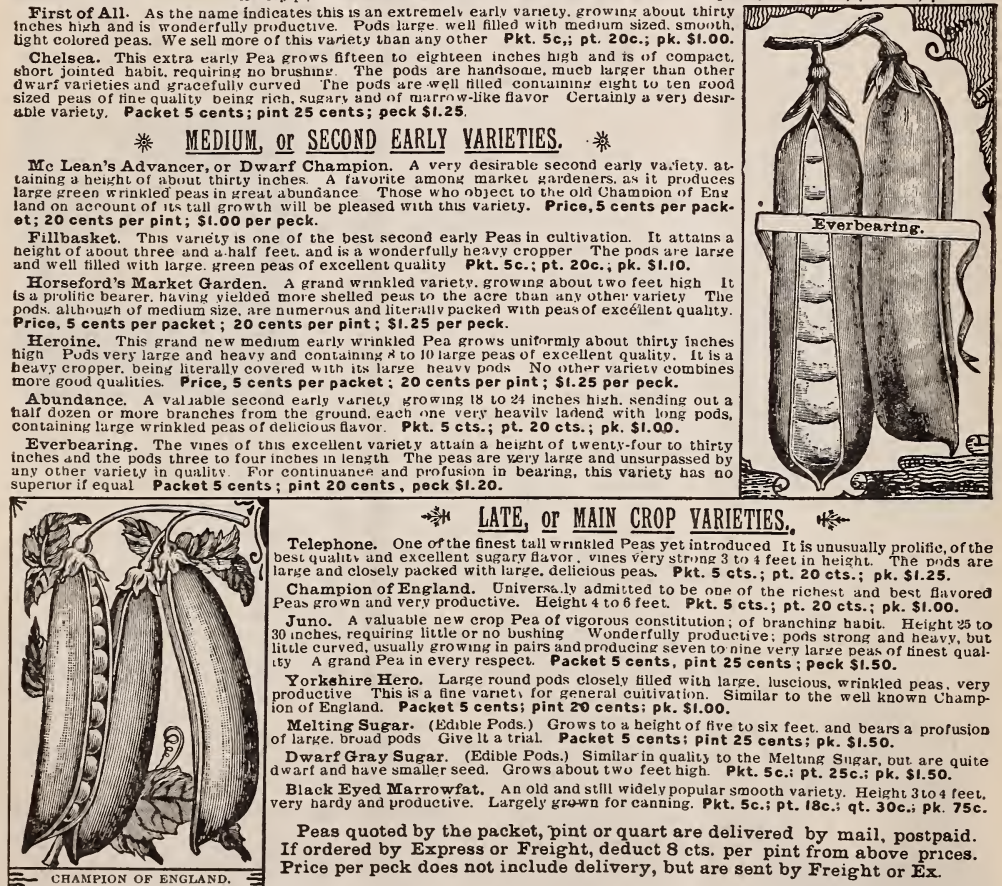

* LATE or MAIN CROP VARIETIES. H

Telephone. One of the finest tall wrinkled Peas yet introduced It is unusually prolific, of the best qualit and excellent sugarv favor. vines very string $3 \mathrm{t}($ ) 4 feet in height. The pinds are large and closely packed with large. delicious peas. Pkt. 5 cts.; pt. 20 cts.; pk. \$1.25.

Champion of England. Universa.ly admitted to be one of the richest and best flavored Juno. A valuable new crop Pea of vigorous constitution; of branching hapi. Height 25 t Juno. A valuable new crop Pea of vigorous constitution; of branching babit. Height 25 to
30 inches, requiring little or no bushing Wonderfully productive:

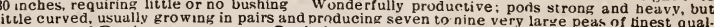
t5 A grand Pea in every respect. Packet 5 cents, pint 25 cents; peck $\$ 1.50$.

Yorkshire Hero. Large round pods closely tilled with large, luscious, wrinkled peas, very productive This is a fine variet, for general cuitivation. Similar to the well known champ on of England. Packet 5 cents; pint 20 cents; pk. \$1.00.

Melting Sugar. (Edible Pods.) Grows to a height of five to six feet. and bears a profusion flarke. bruad pods Give li a trial. Packet 5 cents; pint 25 cents; pk. \$1.50.

Dwarf Gray Sugar. (Edible Pods.) Similar in quality to the Meltung Sugar, but are quite dwarf and have smaller seed. Grows about two feet high. Pkt. 5 c.i pt. 25 c.; pk. \$1.50.

Black Eyed Marrowfat. An old and stlll widely popular smooth variety. Height 3 to 4 feet. very hardy and productive. Largely grown for canning. Pkt. 5c.; pt. 18c.; qt. 30c.; Pk. 75c.

Peas quoted by the packet, pint or quart are delivered by mail, postpaid. If ordered by Express or Freight, deduct $8 \mathrm{cts}$. per pint from above prices. Price per peck does not include delivery, but are sent by Freight or Ex.

the Seedsmen who represents his Melons as growing so large that you must lav down the fence tu roll them out of the patch. whose Onions grow as large as wash tubs. whose Beets may be used as gate posts, or whose Cabbage grow so large that it requires a ladder to climb whose seeds generally are the only seeds worth planting" We cunnot think it is necessars to resort Seedsmen In A nerica. and der to secure patronage. We do not claim our seeds to be of any better quality than other reliable Seedsmen handle. We aim to procure the best grade of seed in the market. whlch we carefully test and put up in large well tilled packets. We en: deavor to give true descriptions and lllustrations of the best standard varieties, and will rely on the good sense and judgmeat 

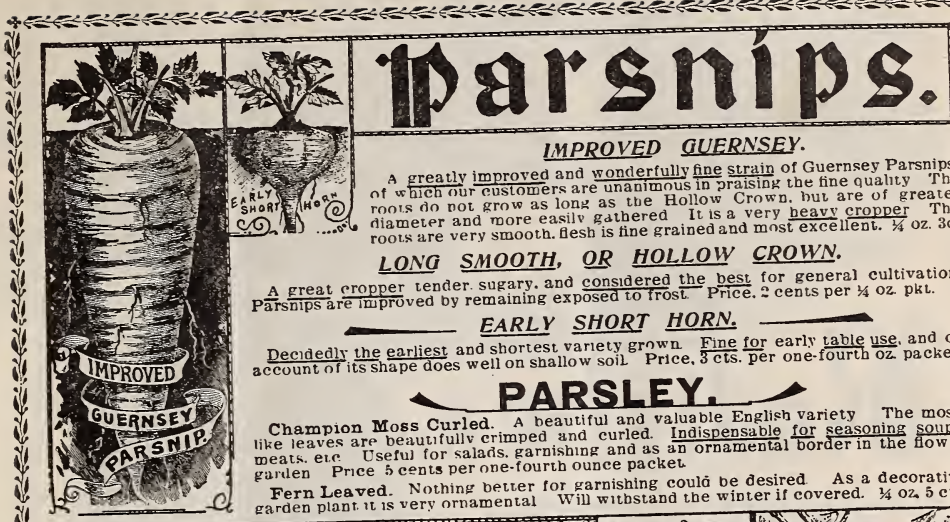

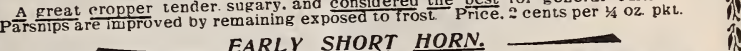

Decidedly the earliest and shortest variety grown Fine for early table use, and on account of its shape does well on shavion

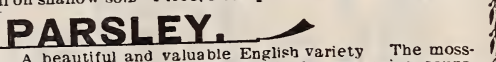

Champion Moss Curled. A beautiful and valuable Engle for seasoning soups.

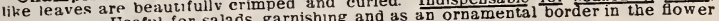
meats. et.e. Useful for saians. -ourth ounce packet.

garlen Price 5 cents per nne-fourth ouning coulá be desired As a decorative Fern Leaved. Nothing better for garnishing could be winter if covered. $1 / 402,5$ cts.

SWEET PEAS.

100 varieties.

The most complete assortplete ever offered for the price. SEE PAGE 27

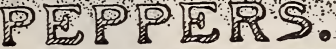

Eace packet of Pepper Seed will contain one-eight oz.. or about 300 seeds. tain oner 60 cents per quarter pound.

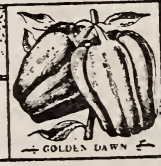

Color bright

Ruby King. The earliest and handsomest of all the red Peppers. Color bright rosv red. and remarkably mila in to tive in diamer Price. 3 cents per packet.

Golden Dawn. Not quite so large as Golden Queen. but more productive of excellent quality. being remarka

Sweet Mountain, or Mammoth. Similar in shape to the Old Bell. but of much

arger size rind thick. Heshy and tender $\underline{\text { Much }}$ used

Red Cherry. A single plant will bear hundreds of bright coral red.

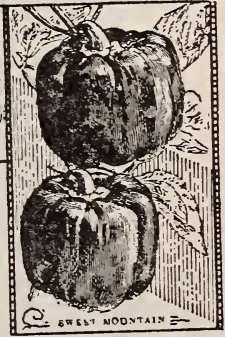

Red Cayenne. A long. slim pointed pod. bright New Celestial. A pepper wonder from China. Ner

New Celestial. A pepper wonder from China. Not coral red when ripe Extremelv strong and pungent only usefive single plants produce 400 to 500 Peppers.

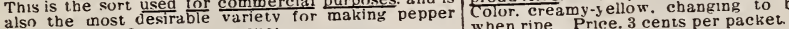
sauce Price. 3 cents per packet
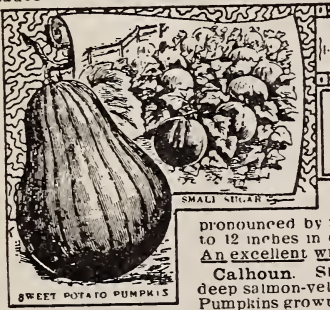

\section{"SOME PUMPKINS." \\ SOME}

Each packet of Pumpkin Seed.

ontain one-half of an

Price. in quantity, 20 cents per

fourth pound: 60 cents per pound.

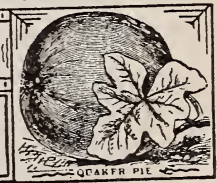

Winter Luxury This raluable new Pumpin is the result of

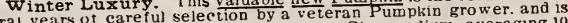
pronounced by man

to 12 inches in diameter Color, rieb golden-yellow finelv nett

An excellent winter keeper Try it Price. 5 cents pered Skin ereamy brown. flesh Calhoun. Snape nearlv round. somewhat flattened Skin creamy brown. deep salmon-vellow very thick. tine grained and $\frac{\text { of }}{\text { pexcellent }}$

Pumplins grown for general use Price. 3 cents per packet. Yankee Pie, or Small Sugar This is the noted New Engary favor Unequalled for pies. Pkt 3 cents.

Fine trained. very productive and keeps well. lesh the sugary das Sweet Potato. A pear shaped pumpNew Golden Oblong A very tine. new and pro- Tennesee sweet in color. sometimes striped with ductive variety. a veraging 75 to 18 inches in length. changing to golden-vellow as it. ripens. Flesh rich vellow verv sweet dry and excellent for ples. W all winter in a conl drv ronm packet 3 cents

Jonathan, or Large White Cushaw Pronounced by a veteran Pumpkin $y$ rower to be one of the finest varieties he has ever grown very prolic ind Price. 3 cents per packet brittle quality the very $\frac{\text { vest }}{\text { Price. } 2 \text { cents per packet }}$

her State $w$ here it has been grown for many years in a settlement of Quakers. or Friends. The shape is nearso ovel tapering slightly towards both ends. Color is (v) is sweet and creamv-wite excellent keever Pkt 3 cents.

SOMETIMES Seeds don't come up just right, owing to a hard crust on the ground. I

bred chickens They have 5 different varleties all also furnish turkeys, ducks and geese 


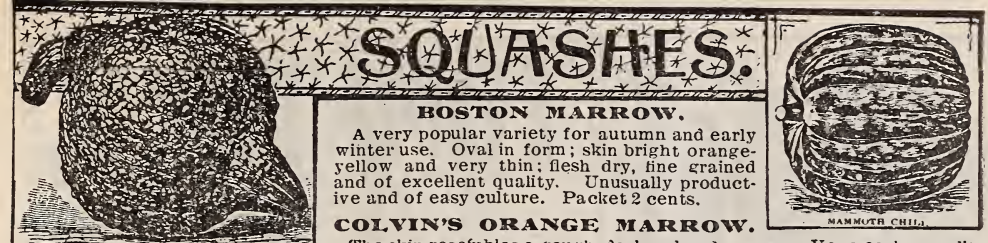

The skin reseímbles a rough, dark colored orange. Very early; quality excellent when matured. May be used when young same as Summer Squashes, also fine for a utumn and early winter Weight 10 to 15 pounds. Pkt. 3 cts.

GIAN'T BUSH SUMMEIR CROOKNECR.

A beautiful bright yellow summer Squash, twice as large as the ordinary summer Crookneck, far more warty and several dass earlier. Bears all summer and is desirable for the private garden or for market. Price, 2 cents per packet.

MAMMO'TH YEILOW BUSH, OT GOLDEN CUSTART.

This is an improved type of the popular old Patcypan Squash. They are wonderfully productive and grow to a large size, averaging 12 to 15 inches across. They are fit for use very early. Color, bright golden-yellow. Price, 2 cents per packet.

ESSEX HYIRID.

One of the finest grained, richest flavored, sweetest and most prolific of all Squashes. Ripens early and keeps until the following June. Packet 3 cents.

\section{GENUINE TIUBBARD.}

The most popular winter Squash grown. Everybods knows it without our describing it. We offer seed of the true Hubbard. Price, 3 cents per packet.

\section{CHICAGO WARTED MUREARD.}

This valuable Squash was introduced by a Chicago Seedsmen: It is an ideal Hubbard. It is of large size color, blackish green; shell hard and woody. covered over with warty knobs. It is a Squash that is certain to please everybody who is fond of the Hubbard Should be included in every order. Price, 5 cents per pkt : oz 10 cents; $1 / 4$ 1b. : 55 cents; $1 \mathrm{~b} .65$ cents.

\section{NEW GOLDEN MUEBARI.}

This new Squash, of recent introduction, is a sport from the well known old Hubbard, which it closely resembles in $\in$ very respect except in color, being a bright golden orange, and while it retains all the excellent qualities of the old Hubbard. it is much more vigorous and productive. In keeping qualities it has no superior, keeping perfectly through the winter. Pkt. 5 cts.; oz. 10 ets.; 1/4 lb. 30 cts.; 1b. 75 cts.

Mammoth Chili. The largest Squash in cultivation, frequently attaining a weight of 100 to 200 pounds. Flesh thick. bright orange yellow and of excellent quality considering the size, but of course cannot be compared with some of the smaller varieties in quality. Productive and a good keeper. Pkt. 5c.: oz. 10c . 1/4 lb. 25c.

Brazilian Sugar. This distinct variety is the richest flavored and $s$ weetest of all Squashes. Fine for table use in every stage of growth. Enormously productive, a single plant has yieldea as many as twelve perfectly ripened Squashes. Flesh yellow, tinted with green. A very fine variety. Price, 3 cents per packet.

Each packet of Squash Seed will contain half an ounce. Price of Squash seed in quantity, except were Prices are given, 15 cts. per $\mid-4 \mathrm{lb}$. $50 \mathrm{cts}$ per lb., postpaid.
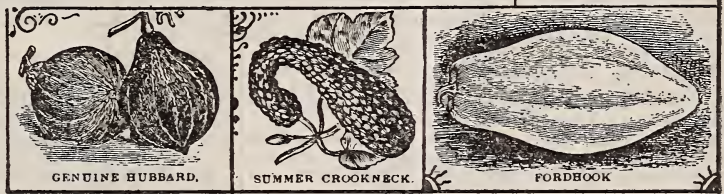

Sandwich Island Salsify.

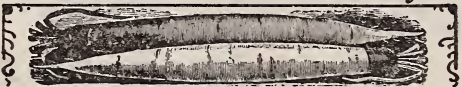

By careful test we find that this new Mammoth Sal sifs grows uniformly to extria large size, averaging fully double the size and weight of roots of the ord variety. The roots notwithstanding their enormous size, a re of superior quality and of very delica te flavor. It is such a decided imprcvement that we are quite sure that all who once try it will use it in preference to any other vartety in cultivation We consiler it so much superior toothers that we offer it only Price, per one-fourth ounce packet 3 cents.

le plant covers a circular space three feet in diameter. Leaves norne well above the soil keeping them clean. are very large and of unusual substance, strong in flavor and of superior quality. A single plant 0 of the common sorts. It is perfectly hardy. In never seeds. Price, 4 plants for $25 \mathrm{cts}$; 10 for $50 \mathrm{cts}$

00 YOUR FRIFAng a favor as well as us by asking them to join vou in ordering Seeds and Plants, or

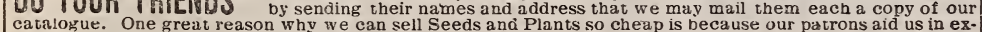
tending our trade by telling their friends where to send their order. It might truth fully be called doing business on the co-operative plan; as we give a share of the profits to our patrons for their assistance by furnishing seeds at reduced prices instead of depending on newspaper advertising which is very expensive. 


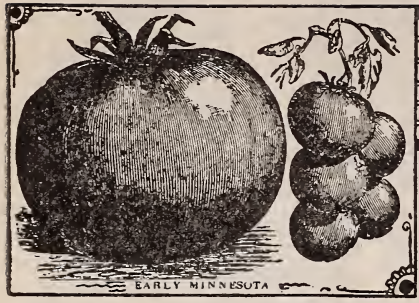

NEW STONE.

Very large and always smooth Bright scarlet: ripens everly to the stem and never cracks, exceedingly solid and fine quality. Pkt. 3 cts., ounce $20 \mathrm{cts}$.

\section{BUCKEYE STATE}

One of the largest perfectly smooth varieties grown. Color, brilliant dark red, very solid and heavy variety for canning Pkt. 3 cents, ounce 20 cents.

\section{MANSFIEID TREE}

A vigorous grower that can be trained to a height of 8 to ten feet. Fruit large. smooth and of good quality. Packet 5 cents, ounce 25 cents.

\section{GOLDEN OUEEN.}

A fine new golden-yellow variety. The fruit is large. smooth and solid. A very desirable variety for slicing or preserves. Packet $\mathbf{j}$ cents, ounce 25 cents.

\section{BEATTY}

A universal favorite. Very productive. uniform. smooth and solid : color, brilliant purplish.scarlet. A Good all purpose variety. Pkt. 2 ets.: oz. $15 \mathrm{cts}$.

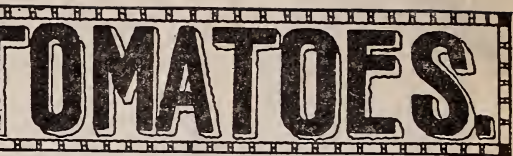

BOND'S EARIY MINAESOTA

There may be otber varieties a few minutes earlier, but none better Always smooth. very early medium size. rich dark red.

\section{ROYAL RED.}

A first class variety in every respect. Of uniform large size. mooth and solid. very productive Highly recommended: said to be a standard medium early variety Pkt. $3 \mathrm{cts}$., $02.20 \mathrm{cts}$.

\section{NEV IMPERIAI,}

We bave now fruited this variety two seasons and are more than pleased. Remarkably vigorous hard and productive Medium large size, always smooth and solid, ripening evenly to the stem. Color. bright red. Very haddsome. Pkt $5 \mathrm{cts}$.: ounce $25 \mathrm{cts}$.

\section{LONG KEEPER}

A desirable new variety. Valuable on account of its keeping qualities. Medium to large size, uniformly smooth; color. bright red. Pkt. $3 \mathrm{cts}$.; oz. $20 \mathrm{cts}$.

\section{IGNOTUM.}

A very popular variety of large size and always remarkably solid and smooth: light red. Pkt. 3c., oz. $20 \mathrm{c}$. PONDEROSA.

The largest Tomato grown. Remarkably solid but not always smooth B. many considered one of the best for canning. Flesh very solid. Pkt. 5c.; oz. 30c.

STRAWBERRY, OR HUSK TOMATO.

Yellow. Very sweet. small. yellow fruit. $3 \mathrm{cts}$. per pkt. of 200 seeds. Purple. A larger and stronger grower: color. light purple. Pkt of 200 seeds 5 cts.

\section{EACH PACKET OF TOMATO SEED WILL CONTAIN SUFFICIENT FOR 300 TO 400 PLANTS.}

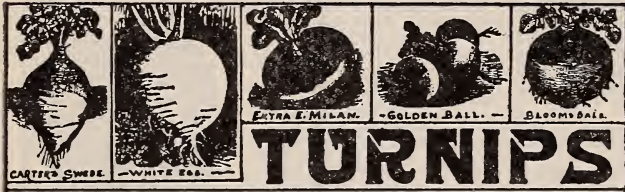

Each packet of Turnip Seed will contain one-half ounce. Price in quantity, $15 \mathrm{cts}$. per $1-4$ pound; $50 \mathrm{cts}$, per pound.

Extra Early Milan. The earliest varlety grown: of medium size, flat and quite smooth with bright purple top, a fine early mar. ket and table variety. Packet 3 cents.

Purple Top Strap Leaf. The most popular variety in cultivation. It is a verv quick grower and the besh is fine grained and sweet flavored. A very handsome variety. Price, 2 cents per pucket.

Early White Strap Ieaf. A very popular market variety. It grows very quickly and matures early. color of skin and flesh pure white. of mild flavor and good quality. Price, 2 cents per packer

Golden Ball. One of the richest. nuost delicate flavored and best of all the yellow flesbed Turnips yet introduced. globe-shaped. matures early, and an excellent keeper. Price. 3 cents per packel.

\section{Ruta Baga, or}

Bnrpee's Breadstone. Desirable for table use. Of quick growth and uniformly smooth, color, white faintly colored at top, flesh white. Pkt. 3 cents

Bloomsdale Swede. Of large size, roundish oblong in form, color. yellow with purple tip. flesh solid and sweet. Fine for table'or stock. Packet 2 cts.
White Egg. Color, clear pure white: perfectly smootn. grows half out of the ground. A choice kind for table use, of excellent flavor, sweet and mild. With its thiv snow-white skin it looks almost as at tractive as would a basket of huge eggs. Six hundred bushels have been grown on an acre. Unsurpassed for market. Price. 5 cents per packet.

Purple Top White Globe. An early globe-shaped variety. a very heavy cropper: in other respects similar to the Red Top Strap Leaf. A very bandsome bulb and is very rapidlv takıng the place of all other varieties of early Turnips for the raarket garden. Price, 3 cents per packet

\section{SPINACH.}

Long Standing. Large, fleshy, crimped leaves. Highly esteemed by many for greens. For winter and early spring use. sow in September in well manured soil. Mulch well with straw on approach of severe weather. Sow in early spring for summer use. This sort is the best for spring sowing. $1 / 4 \mathrm{oz}$. pkt, 2 cts.

\section{Sweedish Turnip.}

\section{Carter's Elephant Swede.}

This fine new Ruta Bdga comes from England where they are noted for growing fine Turnips. Claimed 20 be the largest variety grown. Twenty tons of this variety has been grown on an acre. Unsurpassed for stock leeding. Price, 3 cents per packet. 


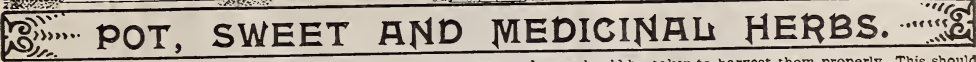

No garden is complete without a few herbs for culinary purposes, and care should be taken to harvest them properly. This should be done on a dry day, just before they come in bloom, then dried quickly and packed closely, entistance apart.

the spring in shallow drills, one foot apart and when we seasoning soups.

Balm. Principally used for balm tea and balm wine.

Sweet Basil. The leaves and tops of the young shoots are used

tor highly seasoned dishes and soups.

Caraway. Chiefly cultivated for the seeds which are used in

confectionery and medicine A very popular herb

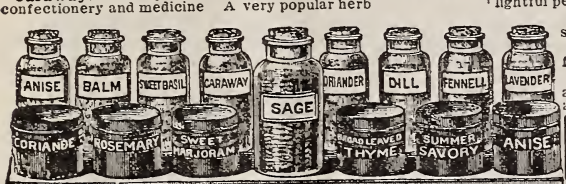

Coriander. Used for garnishing, the seeds for confectionerles. Dill. The leaves are used in soups, sauces, and splced plckles. Horehound. Principally used for medicinal purposes and by Horehound. Vrincipalul as a medicinal herb.

Lavender. A very popular aromatic herb emitting a very doSummer Savoy. The leaves and flowers are extenSummer for flavoring, particularly in soups.

Sage. The leaves and tender tops are used in stuffing. or teas, and many other similar purposes.

Thyme. The yount leaves are used for soups, sauce,

Price, 3 cents per packet; one pack. et of each of the above varieties for only 30 cents, postpaid.

Mixed Herbs, An equal mixture

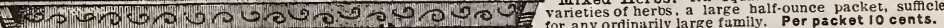
intief . Miscellaneous

Early Armber Sugar Gane.

1t has recently been discovered to be one of the most valuable green fodder and fordue plants. growing ten to twelve feet high, and if planted early in May will ripen the seed, making valuable poultry food. Its greatest value, how ever, is for forage.
cut two or three times. Pkt. 3c.; Ib. 25c. By Ex., pk. $90 \mathrm{c}$.

\section{Mammoth Russian Sunflower.}

Unsurpassed for poultry food, also largely planted in the West for fuel where timber is scarce. Grows rapidly in any soil, single heads sometiunes measuring will plant an acre of ground. $0 \mathrm{x}$. pkt. $5 \mathrm{cts}$.; pint $18 \mathrm{cts}$.; quart $30 \mathrm{cts}$.

New White Beauty Sunflower. Here is a novelty indeed. A Sunflower having pure snow. white seed. It is a vigorous grower and wonderfully productive, producing one immense head on each stalk without branchin it.yields as high as 3.000 pounos on an acre: unsurpassed for poulper ounce $10 \mathrm{cts}$.; pint 25 cts.; quart $40 \mathrm{cts}$.

\section{German Coffee Berry. (SOGA BEAN.)}

This valuable foliage plant has attracted increased attention yearly. It is one of the most nutritious of all vegetable products. It $w$ ill produce twenty to thirty bushels per acre and are us easily grown as other beans. For pasturing or as green fodther notable use and for that purpuse has been widly advertised an sold recently. It is called the German Coffee Berry, also American Colfee Berry.

A prominent seersmen says. "It is a fact, as we find it by actual test, that when roasted and coarsely ground, it tastes so nearly like Brazilian coffee the dif

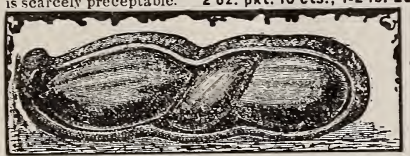

Virginia Improved Peantut.

Evergreen Broomcorn.

Seeds.........

The best variety for reneral cultivation on a ccount of color and Price, 25 cents per und, postpaid. By express, 10 pounds for $\$ 1.00$.

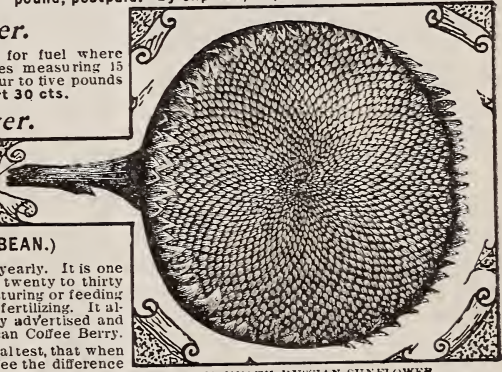

This mammoth Virginia Peanut is a very profitable variety to grow, and more tesiruble than the common spreading kinds. It is easuly cultivated, having very erect stems and upright foliage, largest pods and kernels of uny variety, also Have jour children try it. Price, large packet 10 cts.; pint, 25 cents.

\section{SPANISH PEANUT.}

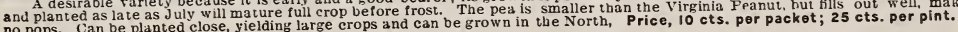

\section{KAFFIR CORN.}

RHUBARB, or pie Plant.

raluable feet, producing large heads of grain. Excellent for stock or poul. and pies, also as sauce. 1t is verr wholesome and should be in every try. Yields 50 to 60 bushels per sere and 5 cts pound, 25 cts.

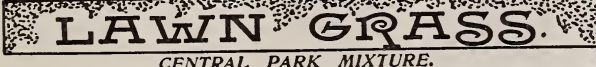 \\ Nothing adds so much to the beauty of a home as a nice well} kept lawn, and in order to successfully produce a new lawn it is necessary to sow specially prepared seed. We offer the Centra? Park Mixture which is the same as used in the Parks of New York and other large cities. One quart will sow about three hundred square feet. Three or four bushels are required to sow an acre. Sow as early in the spring as the soil can be prepared. Care should be taken to have a well prepared, even surface, always bearing in the seed in the clay from the cellar or well

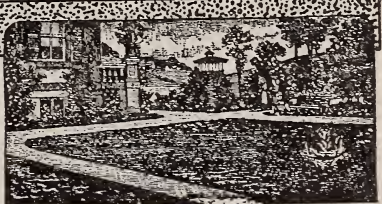
mind that it requires a good soil to grow a fine lawn. Son't sow is also a good time to start a lawn. After and expect good results. Last of August or tirst of September is also a good tim soun have a fine lawn.

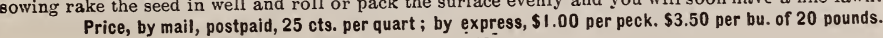




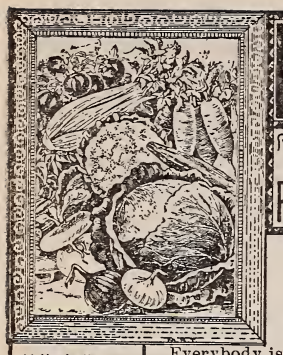

FAMIL POLERION

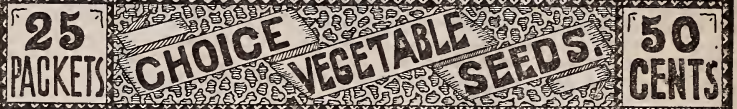

$\mathrm{F}_{6}$ OR many years we have been offering our popular Family ands of these collections, and the universal verdict is that it is the largest and most complete 50-cent collection of garden seeds on the market. In fact from the many thousand collections that we have sold we have never read a single word of complaint.

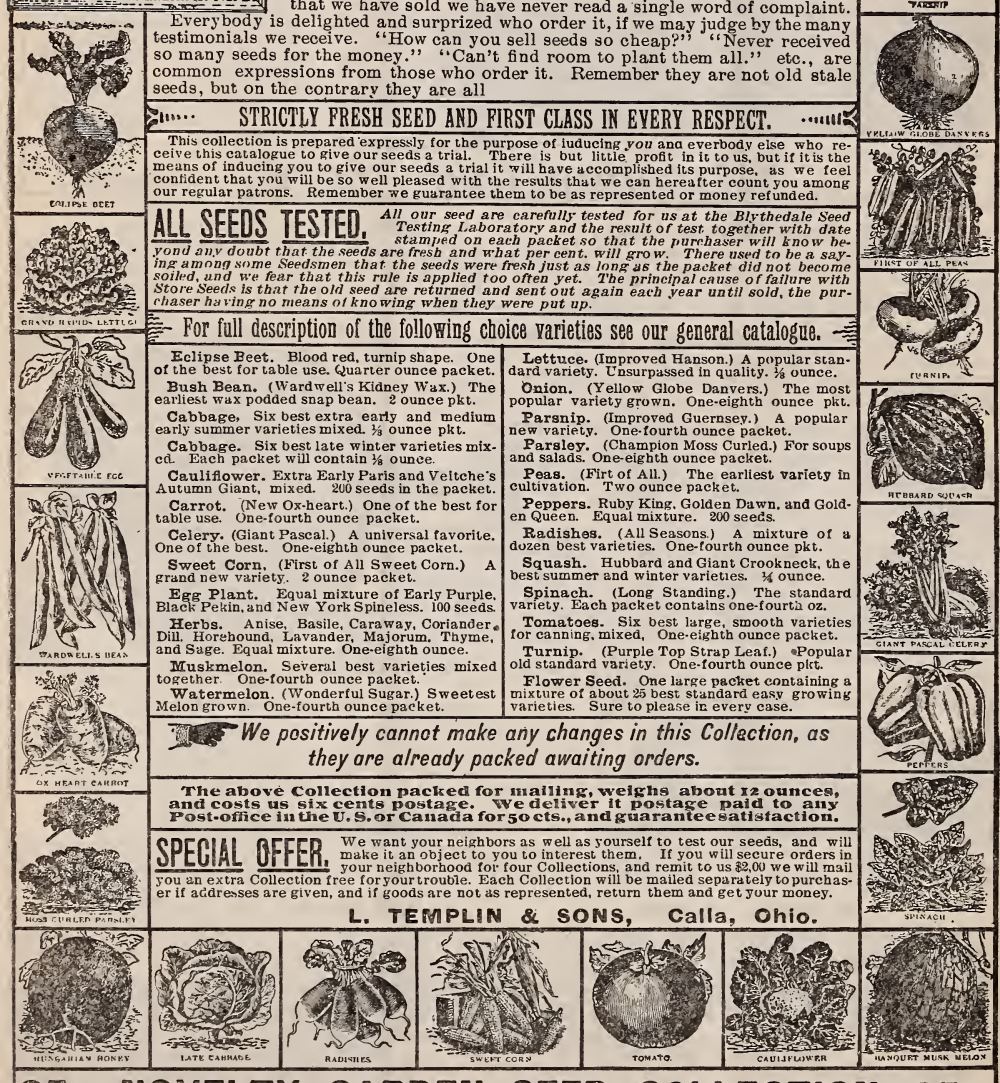

$$
\text { w }
$$

25c. NOVELTY CARDEN SEED COLLECTION. 25c.

ew varieties of seed are always much higher in price than standard varieties. Purchasers would often like to test them, but do not

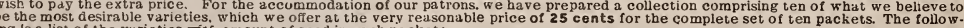
ing is a list of the varieties witi nmount of seed in each packet. Now Emerald Cucumber. One-eighth ounce packet. New Rose Ribbed Paris Celery. Packet 250 seeds.

New Ball Head, or Hollander Cabbage. Pkt. 250 seeds

Crisp-as-Ice Lettuce. Une-eighth ounce packet.

New Kinsman Queen Musk Melon. Packet 100 seeds.

New Kleckley Sweet Watermelon. Packet 50 seeds.

New Australian Brown Onion. Packet 250 seeds.

New Zempfer Parsnip. One-eighth ounce packet.

New Triumph Striped Radish. Packet 100 seeds

Nev Enormous Tomato. Packet 50 seeds.

The entire collection of ten Choice New Varieties for only 25 cents, postpaid. No changes allowed in this collection, as are already packed a waiting orders. The entire collection must be ordered.

Secure orders for four collections among your friends, send us $\$ 1.00$, and get a free colleetion for your trouble. 


\section{$\therefore$ F Few Choice Vegetable Seed Novelties..}

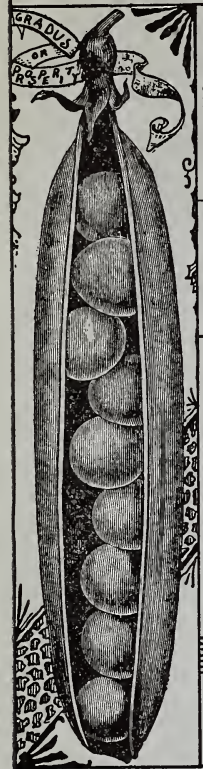

PROSPERITY, OH GRADUS PEA.

A LONG STEP TOWARD PROSPERITY IN THE PEA WORLD.

earliness and is very productive. The smooth varieties of Extra Early Peas have heretofore filled their

weather. but there has been the need of an "extra early" which would always have the sweetness and fine fla-

vor of the wrinkled varieties. "Gradus" therefore fills the want, and is the first extra early wrinkled pea. It is

hatf feet high and is very prolific, bearing pods fully as large as Telephone, usually containing from 8 to 10 large

peus The color of leiled

10 conts; one-half pint 20 cents; pint 30 cents.

NEW GIANT GREEN POD STRINGLESS VALENTINE BEAN

The Round Pod Valentine Bean has long been one of the most popular with market gardeners. but outside of unproving slightly the existing type, nothing has been achieved to better it materialy. Now, however, a new

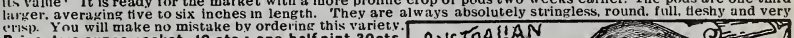
Price, two ounce packet, $10 \mathrm{cts}$.; one-half pint $20 \mathrm{cts}$.
Prous

EXTRA EARLY LONG KEEPER.

AUSTRALIAN BROWN ONION.

\section{EARLY FORDHOOK SWEET CORN.}

Early Fordhook is the largest eared extra early corn, averaging in length seven inches. The grains and cob are pure white. The ears are eight-row ed with small cob and deep grains. dass later so it may be said to equal Corv in earliness. while surpassing any other extra early Sweet Corn in size, quality, sweetness. and
entire freedom from smut. Pkt. $10 \mathrm{cts}$.; pt. 25 cts.; qt. 40 cts.

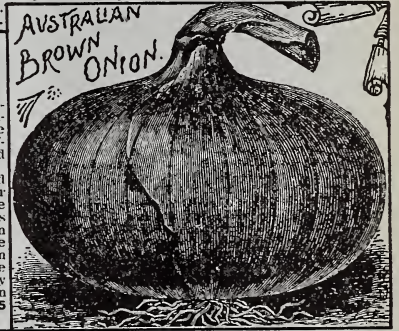

\section{...New Rose Ribbea Celery...}

This beautiful new Celery is a sport of the Golden Self Blanching and possessing all the good qualities of that . We believe this variety will surpass all others in quality and appearance. Price, 10 cents per $1-8$ ounce packet.

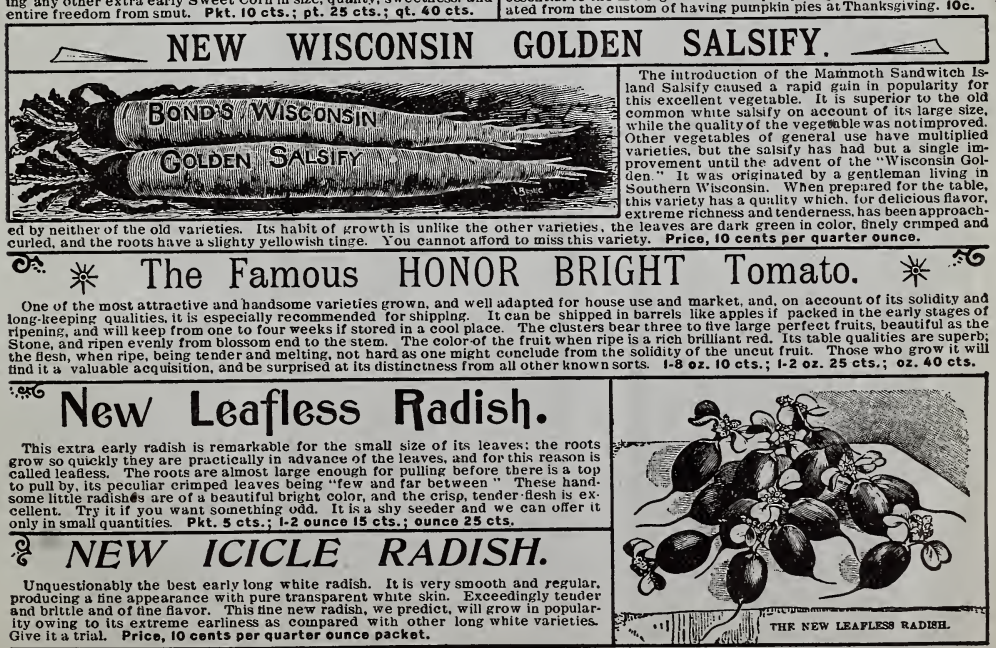




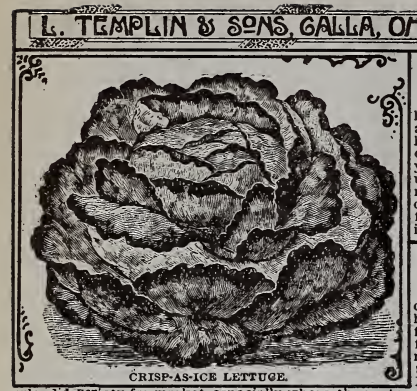

\section{CRISP-AS-ICE LETTUCE.}

A beautifu! new lettuce of the cabbage type. The solli heads are of immense size, and so tender and brittle. as, to
account for the name bestowed upon the variety. The leaves are thick and glossy and some what curled, of a green yellow heart. This lettuce cannot be overpraised for home use in spring and summer, but it is rather too brittle for of its size. One of the best bead lettuces ever grown, elther for.sowing early in tot-beds for transplanting or for sowing
in the open ground for summer use. Packet 10 cents.

\section{Zimpier Parsnip.} splendid veriety for market, especialy where the roots are sold in bunches, being of much more desirable shape than
any of the Hollow Crown or Cup varieties. It is sweet, smooth and very white. 10 conts per quarter ounco.

\section{The Enormous Tomato.}

This wonderful new Tomato was intróduced last season. The name Enormous was selected on account of its enormous size. It is truly enormous in size and the peer of other varieties in every otber respect. It is not early but one of the best main crop Tomatoes ever put on the market. This is
tested it. Give it a trial. Price, 10 cents per packet of 250 seeds.

\section{"गन्द्न'BURPEE'S "GOMBINATION TOMATO."}

A splendid sort for home use, market, or canning. Of vigorous growth. the vines are yet very short snd fruitful. In color the skin is of the brightest. shining scarlet, size is medium to large, round, smooth, and free from cracks. An average specimen measures from $3 \frac{1}{3}$ to 4 inches across and about 2 inches thick. The flesh ls solid and the large the crop of fruit is borne exposed to the sun and hence-ripens well. The vines mature the tirst fruits fairly early and continue bearing tine Tomatoes until cut down by the frost with few, if any. small fruits. Special mening nearly four weeks; this alone is suffeient to warrant its future popularity. Packet 250 seods 10 conts.

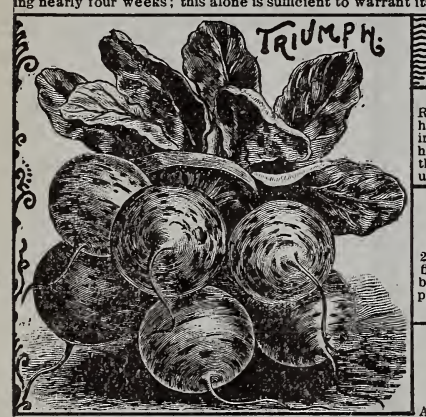

TRIUMPH RADISH

Striped, Red and White

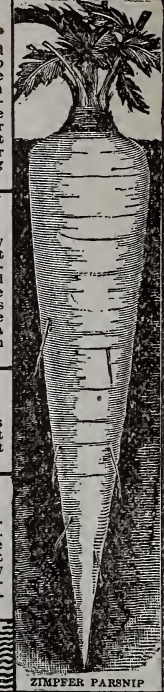

This is a beautiful and odd Radish. which when mixed in the bunch with Scarle Radishes makes a pleasing contrast. The Radishes are globe shape and strikingly ing variety, with short top, small leaves, and matures quickly. The warmth of the hot-bed makes its peculiar colorings quite prominent. It can also be grown in the upen ground, and is of mild pleasing favor. It is very ornaniental for table use. Sold in packets only. Price, 10 cents per $1-8$ ounce Packet.

\section{NEW KLECKLEY SWEET WATERMELON.}

Mr. Burpee says that this is The finest table Melon grow'n. Fruit oblong, 15 to 20 inches in length, skin darls green, flesh bright scarlet ripening close to the skin; back to this grand Melon is that the fruit is too tender and brittle to stand ship. ping. We purchiased our seed from Mr. Burpee, the origins tor,

Price, per 1.4 ounce Packet 10 cents ; ounce packet 20 conts.

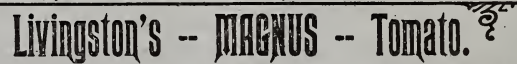

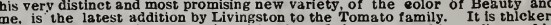
hea vier, and more solid than either of the above, making it easily the most handsome sort in cultivation. 1t is unsurpssed in quality, and in the production of the. large truits. While perfectly adapted to main crop planting, yet it matures so quickly that it will take trst rank for early market. The form is perfect. uniform. large. and attractive. Foper. The fruits are very deep from stem to blossom end, unany

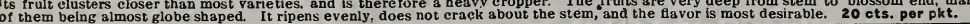

\section{$\because$ NEW YELLOW PRINCE TOMATO.}

A fine new yellow Tomato of dwarf, compact, upright growth, as early as Dwarf Champion: of large size, smooth, and solid, favor very desirable. On account of its dwarf compact habit it can be plante
rieties. Price, 5 cents per packet of 100 seods.

NEW PEA, -- IMPROVED PRIDE OF THE MARKET.

The Pride of the Market has atways been recognized since its introduction as having the thest quality of the large-porded $d w$ to supply the demand. a very strong indication of the aphave been eliminated all of the small round pods which sometimes appeared in the variety, so we now have a strain producing uniformly large, handsome, dark well thled with large peas of the hnest quality. The pods mature ben to the same time as those of Telephone, but is the vines lis, making it very desirable for smill gardens as well as for teld culture on a large scale. Where it 5 ould be too expenslve to furnish supports. Furthermore, grow $\mathrm{n}$ in the space required for $t w o$ of the origlnal strain, so that it will yleld at east tifty per cent, more to a given space Prico, 10 conts per packet.

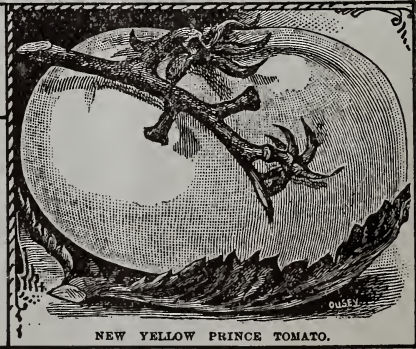

\section{The Wonderful NeW APRICAN HORNED CLIMBING CUCUMBER.}

This is one of the most distinct and novel introductions of mahy gears. In leaf, vine, and fruit it is quite distinct from all other Cu cumbers. It is a remarkably rapid climber, and will soon cover a trellis space of ten feet square. or more. with a solid sheet of grees through which the sun cannot penetrate. Distlnet and curious: averages three inches in length by two in dlameter: is some what three. sided in shape and covered with strong protruding horns: skin smooth; truit when ripe turns \& brilliant orkage red and yellow in speclied

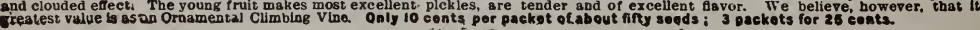




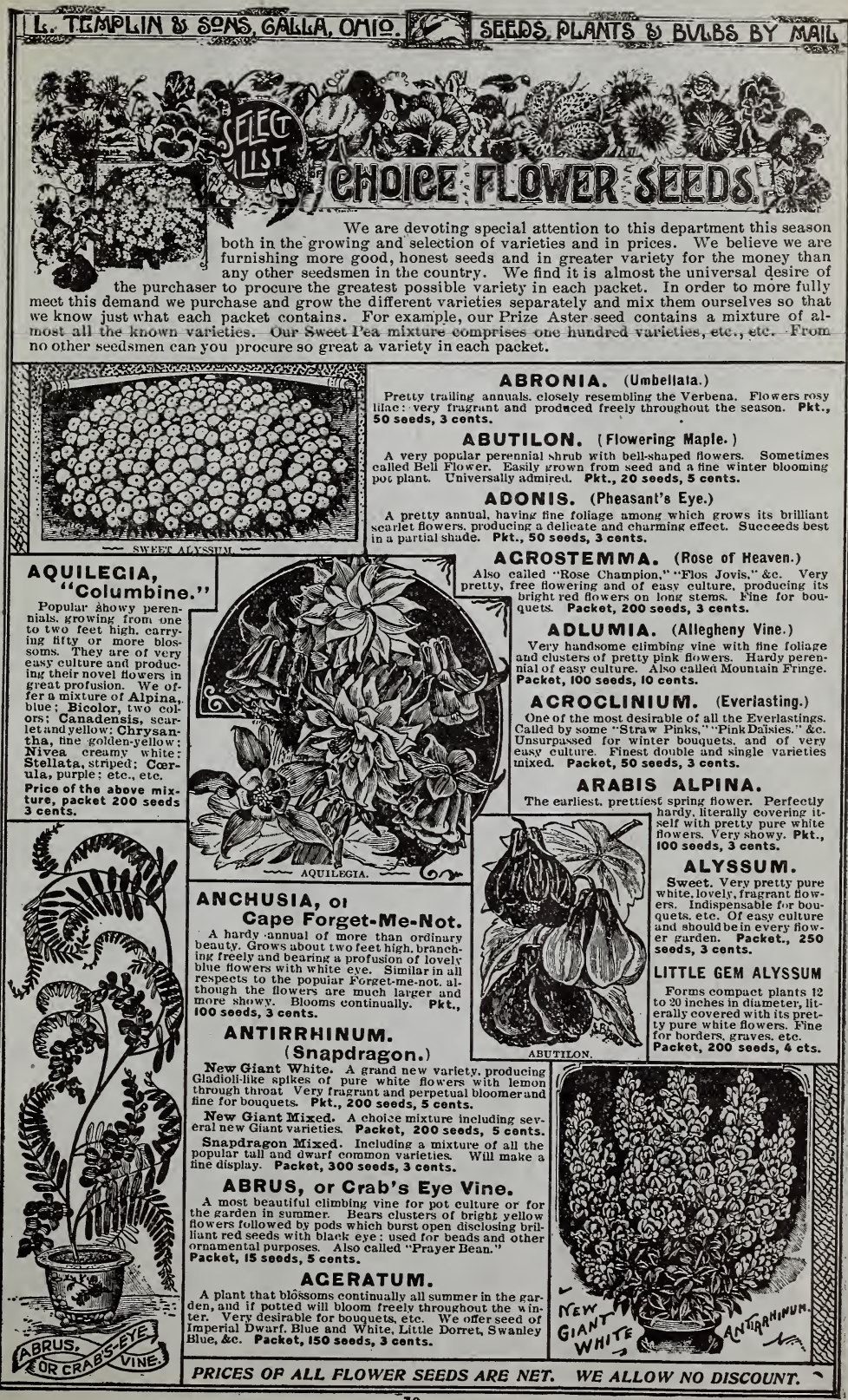




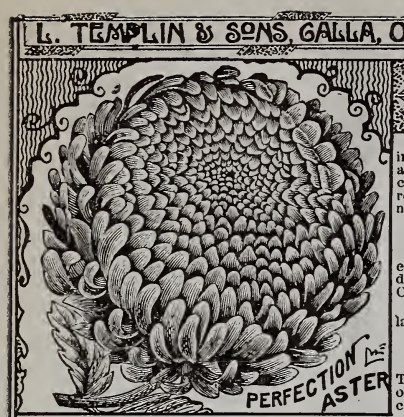

OMIO 19 SEEDS, PLANTS \& BULS BY MALL

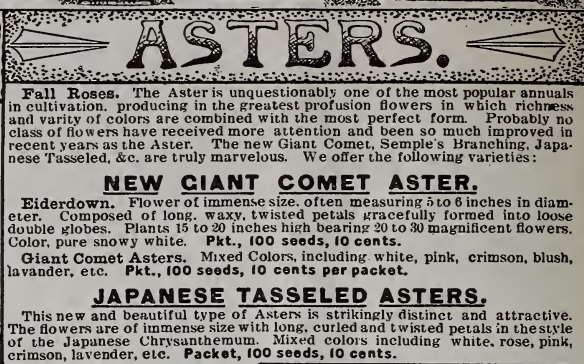

\section{PERFECTION ASTERS.}

One of the most perfect and deservediy the most popularot all Asters. Very large.

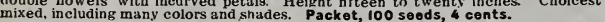

Perfection, Snow White, Pink Ball and Crimson Ball. Each color, 100 s, $5 \mathrm{c}$. I FIRE KING ASTER.

The most brilliant Aster ever introduced. Of dwarf, crimped habit, with large beautifully incurved petals. Color intense glowing brilliant red, almost scarlet. A very pleasing variety. Try it. Packet, 100 seods, 5 conts.

\section{SEMPLE'S NEW BRANCHINC ASTER.}

Strong, robust, bushy plants $t$ wenty inches to two feet high. bearng profusely on long steuns handsome. large. double Chrysanthemum-like fowers four to live inche

Semple's Branching. Pure white flowers. Packet, 100 seeds, 6 cents.

\section{$\longrightarrow$ VICTORIA ASTERS.E}

Magnificent flowers, massive and showy with regular overlapping petals. Plants pyramidal in form and about eighteen inches in height. Flowers three to four inch-
es across. Over $t$ wenty colors mixed. Packet, 100 soeds, 5 conts. $\Rightarrow$ MICNON ASTERS.E

A fine new class. The plants are semi-double, bearing 40 to 50 beautifullv shaped.
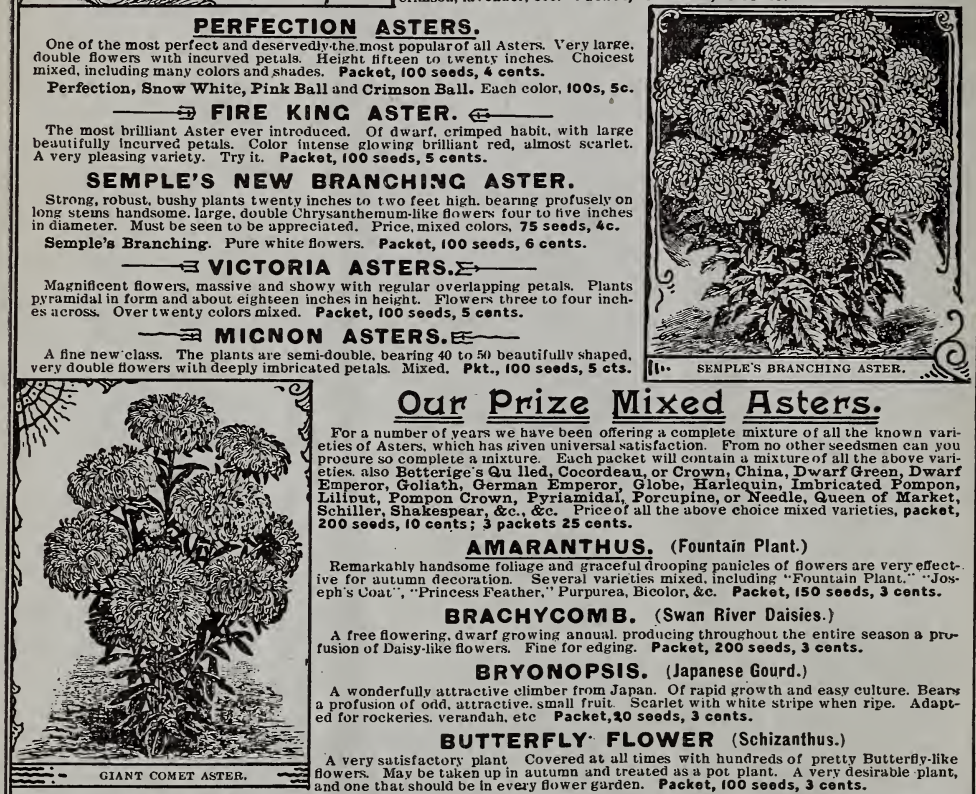

\section{Our Prize Mixed Asters.}

For a number of years we have been offering a complete mixture of all the known varieties of Asters, which has given universal satisfaction. From no other seedsmen can you ptiex. also Betterige's Qu lled, Cocordeau, or Crown, China, Dwarf Green, Dwarf Emperor, Goliath, German Emperor, Globe, Harlequin, Imbricated Pompon, Schiller, Shakespear, \&c., \&c. Price of all the wbove choice mixed varieties, packet, Schiller, Shakespear, \&c., \&c. Price of
200 seods, 10 cents ; 3 packets 25 cents.

\section{AMARANTHUS. (Fountain Plant.)}

Remarkahly handsome foliage and graceful trooping panicles of fowers are very effective for autumn decolation. Several varieties mixed. including "Fountain Plant." "Jos
eph's Loat", "Princess Feather," Purpurea, Bicolor, \&c. Packet, 150 seods, 3 cents.

BRACHYCOMB. (Swan River Daisies.)

A free flowering, $d$ wart growing annual. producing throughout the entire season a prufusion of Daisy-like flowers. Fine for edging. Packet, 200 seeds, 3 cents.

BRYONOPSIS. (Japanese Gourd.)

A wonderfully attractive climber from Japan. Of rapid grow th and easy culture. Beary profusion of orda, attractive. small fruit. Scarlet with white stripe when ripe. Adaptd for rockeries. verandah. etc Packet, 20 seods, 3 conts.

\section{BUTTERFLY. FLOWER (Schizanthus.)}

A very satisfactory plant Covered at all times with hundreds of pretty Butterfy-like fowers. May be taken up in autumn and treated as a pot plant. A very des
and one that should be in every fower garden. Packet, 100 seods, 3 cents.

BIRD OF PARADISE. (Poinciana.)

The color of fow er is golden-yellow, and are prodiced in large trusses. The most showy part about the fower is the large pistiles which are bright crimson
and spread out in fan-like form. It makes an excellent pot plant. or may be krown in the garden during summer. Packot, 12 seeds, 10 conts.

BALSAM APPLE. (Momordica.) A beautiful elimbing vine with pretty fruit which. if preserved in alcohol,
makes a most useful lintment. Very attractive. Packet, io seeds, 3 cents.

\section{BALLOQY VINE. 王}

A rapid growing, handsome climber wh an inflated seed pod from whlch it deZI BROWALLIA. E

A handsome and profuse bloomer. Cseful for both house culture and the garden. Very easily grown ann of much value for cut flowers. Very attractive. Blue and white mixed. Packet, 200 seeds, 5 cents.

\section{ב BECONIA VERNON.}

A most satisfactory pot plant for the honse. and a popular bedding plant for the karden or lawn. Flowers brtliant orange carmine with yellow centre. It is
easily raised from seed. Vuluable for bedding. Packet, 150 soods, 5 conts.

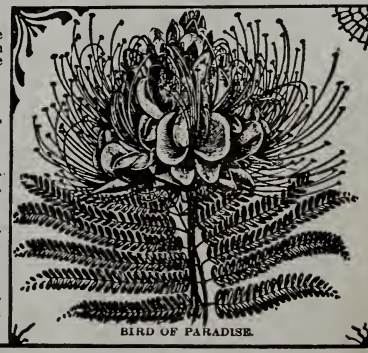

See page 27 of this catalogue if yon want to secure the most complete assortment of SWEET PEAS ever offered. 


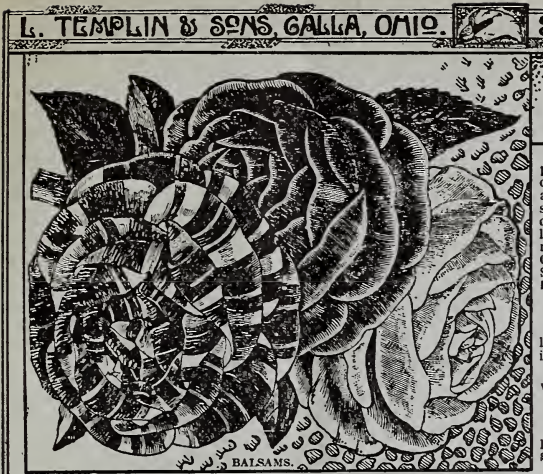

\section{BACHELOR'S}

\section{BUTTONS.}

(Centaureas.)

\section{BNLSNMS.}

New Centaurea Margurite. A beautiful new annual, and the handsome

known. Should be in everv garien. Grows fifteen to twenty inches high Flo
ers pure white. exquisitely fragrant and beautifully fringed. Pkt., 50 soeds, $10 \mathrm{c}$.

Bachelor's Button. "Corn Flower," "Blue Battlex," "Ragged Sailor," \&c. Pop-

New

double flowers. Choicest varieties mixed. Packet, 50 seods, 5 cents.

CENTAUREA. (Dusty Miller.)

A valuable silvery white, ornamental leaved plant. Much used
ribtoon bedding. Of very easy culture. Packet, 50 seeds, 5 cents.

CALLIOPSIS, (or Coreopsis.)

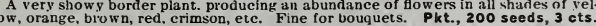

CANARY BIRD FLOWER.

One of our most beautiful annual climbers, with
bifight green delicate cut foliage, and peculiar shidd-

\section{CALCEOLARIAS.} vatory. The flowers are remarkable for their odd Seeds beiny very tine requires care in sowing

acket, 100 seeds, 10 cents.

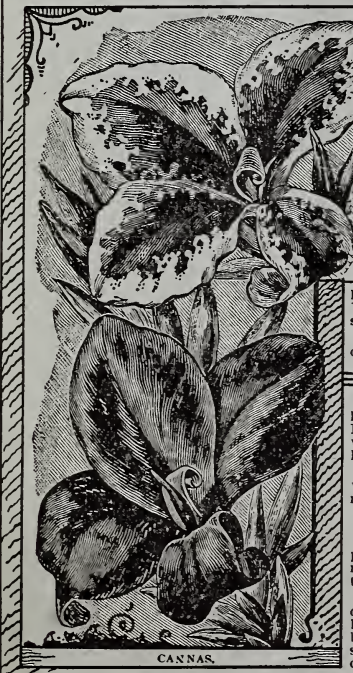

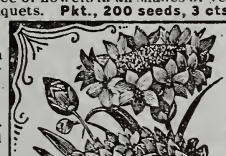

ins
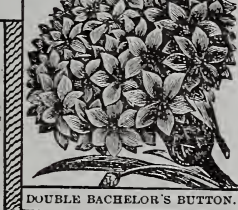

CROZY'S NEW

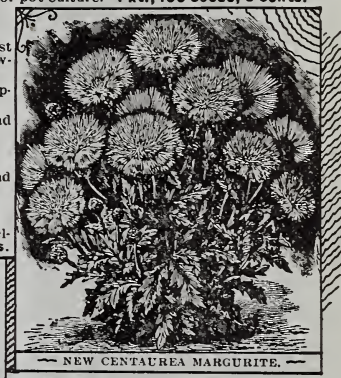

CACALIA. (Flora's Paint Brush.) Tassel Flower.

三 CATCHFLY. $\equiv$

ery free flow ering annuals. producing elu of pretty small flowers. Desirable for

Packet, 200 seeds, 5 cents.

CALENDULA. (Pot Marigold)

Beautiful large, double shorg forw duced in the yreatest profusion owers. prothe entire summer. Sow the seed in the open llow and white mixed. 50 seeds, 3 cts.

\section{DWARF CANHAS,}

age plant grown. Will blonm the tirst year from seed The roots may be wintered in a dry cellar where hart shell of the seed: soak in warm water over night and plant in warm soil.
With this treatment they germinate as freely as Corn. We offer choicest mixed seed saved from Crozy's large flowering dwarf varieties. I5 seeds, 5 cents. Tall Cannas. The popular old large growing varieties, forming massive clumps fornamental foliage. having a pleasing effect Packet, is seeds, 3 cents.

\section{CANDYTUFT.}

One of the most popular annuals in cultivation. Very hardy and easily grown. Indispensable for bouquets. (1) Rocket.. \&c. Packet, 200 seeds, 3 conts.

New Empress Candytuft. A strong free grower mense trusses of pure white flowers. 100 seeds, $4 \mathrm{c}$.

CHRYSANTHEMUMS.

Japanese Show Varieties. The well known and popular autumn tiowering show varieties. Choice ties Packet, 75 seeds, 10 cents.

Annual Chrysanthemums. These are becouning quite popular Thes are sometimes called Fainted being put on with a brush. They are among our most distinct varieties. Packet, 100 seeds, 3 cents.

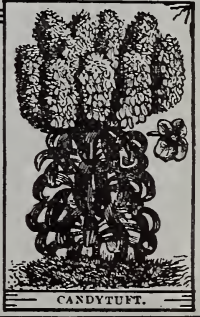

E If you are Interested in Poultry, send for our Illustrated Catalogue of Poultry. 


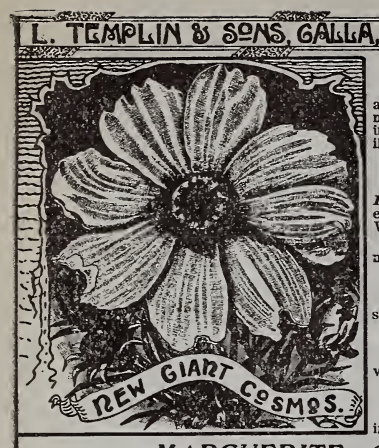

SEEDS, PLANTS \& BVLBS BY MAIL. NEW GIANT GOSMOS.

It is impossible to describe these magniticent flowers. They bloom freely during autumn: the single flowers measuring three inches or more across. They embrace many shades of crimson, pink, white. mauve, etc. The tinted varieties are charm-
ing, the ground being white. flecked and tinted in the most delicate manner. Eas. ing, the ground being white. flecked ard ties mixed. Pkt., 100 soeds, 10 conts.
ils grown from seed. Finest Giant varieties

NEW "KLONDIKE" COSMOS.

A novelty that is really new and one of the most desirable offered in years. An
Early Flowering Golden-yellow Cosmos. Flowers two and one-balf to three inchEarly Flowering Golden-yellow Cosmos, Flowers two and one-bair to three inchWhy not have a golden Klondike in your garden. Pkt., 50 soods, 10 conts. Cosmos Zybridus. The popular autumn flowering Cosmos thut everybods admires so much. Finest mixed including all colors. Pkt., 100 seods, 5 conts.

CLEOME. (Giant Spider Plant.)

A very show y annual with curious heads of bright pink flowers with long stamens, somew hat resembling the eye of a giant spider. Packot, 50 soods, 3 conts.

- COBEA SIANDENS.

A beautiful climbing vine with large bell-shaped aowers of a beautiful deep ב CINERARIA HYBRBDA. E-

A pupular greenhouse plant, producing immense heads of gorgeous flowers, rang CARNATIONS.

These lovely fragrant Carnations produce fine double fowers from seed. similar to those grown by furists during winter. They may be had in full blonm in three to four
months after sowing the seed. The plants succed alike in the open ground or in pots. They are of virorous. dwarf, compact habit. requiring no support. The range of colors.
markings. variegations and shades are simply wonderful. We offer tinest double mixed markings. variegations and shades are sim
varieties. Packet, 100 soods, 10 conts.

CANTERBURY BELL. (Campanula.)

A well known and popular perennial that should have a prominent place in every gar.
den. Finest single and double varieties including many colors. Pkt., 200 seods 3 cts. Cup and Saucer. ing beautiful towers with cup three inehes in length and saucer at base of cup three to four inches across. A very profuse bloomer,
plants producing hundreds of lovely flowers.

COCKSCOMB. (Celosia Cristata.)

Very interesung and attractive annuals that can. not fail to give entire sttisfaction. The combs of - ) shades of red. orange, yellow, etc. Give it a trial.

CONVOLVULUS. (Morning Giory) Everybody knows and everybods grows Morning
Glories. They need nop

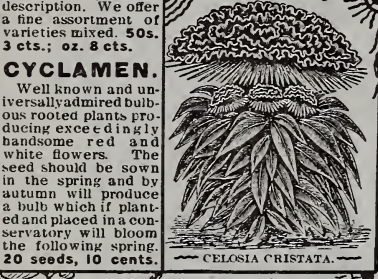

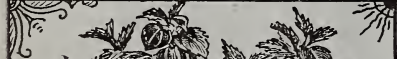
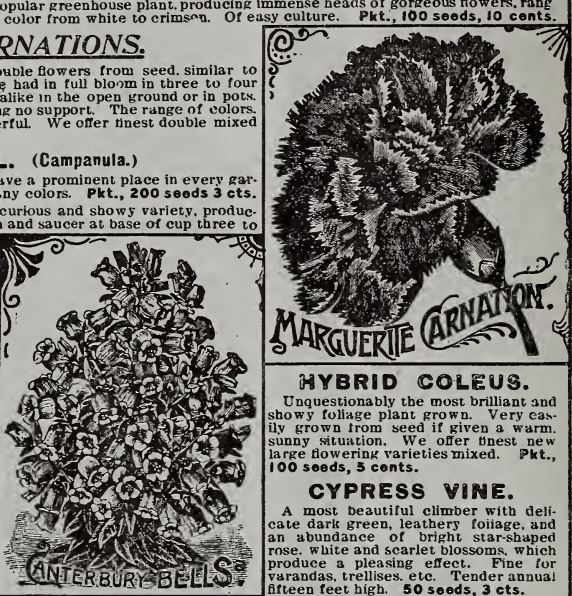

MYBRID COLEUS.

Unquestionably the most brilliant and showy foliage plant grown. Very eas-
ily grown trom seed if given a warm. 14y grown rrom seed ir given a warm.
sunny situation. We offer tnest new large tlowerink varieties mixed. Pkt.

CYPRESS VINE.

A most beautiful climber with delicate dark green, leathery foiiage, and an abundance of bright star-shaped produce a pleasing effect. Fine for varandas, trellises. etc. Tender annua!

WILD CUCUMBER. (Echionseystis.)

Unquestionably the most rapid climbing vine we offer. Unsurpassed for overing varandas, arbors, etc. Will grow thirty feet or more in a single bundance of ornamental prickly seed pods. For a trellis or pillar no vine is more chaste. Will quickly cover old fences and unsightly places. Truly a

\section{CHINESE LANTERN PLANT.}

Physalis. This plant produces numerous large inflated seed pods much the shape of Chinese lanterns. Color at tirst light green, changing to yellow and tinalls when ripe to brightest scarlet. Very show, and attractive.
Branches cut and dried makes beautiful winter decorations. 50s., 10 cts.

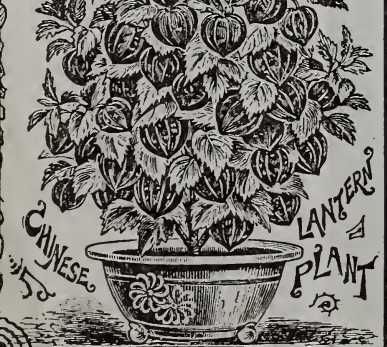

DOLICHOS. (Hyacinth Bean.) A splendid climber, producing abundant clus.
tered spikes of purple and white fowers which are followed by exceedingly ornamental seed pods. Or rapid grow th, often climbing $t$.
feet or more. Pkt., 20 soeds, 3 conts.

DELPHINIUM. (Per. Larkspar.) A grand and showy perennial with tine euc foliage and immenses pikes of beautiful double hrough the differentshades of blue and purple.
All the best varieties mixed. 50 seeds, 3c.

DRACENA INDIVISA.

This is an exeedingly usefut plant for targe specimen pot plant or for centre of vases etc where many other plants would perish. It bas
ong, narrow, graceful drooping green foliage of a beautiful bronzy color, always producin
a pleasing eđfeet. Pkt., 50 seeds, 10 conts.

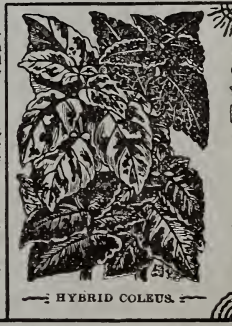

OUR FAIIIY ROLIFTIII If we may judge bo the many unsolicited testimonials we receive from those who UU FAHIL UULLEIIU,, purcbase it, this is unquestionably the largest and most complete assortment filled packets or lust such vaneties as you want for a complete family garden, all by mail. postpaid. for only 50 ce
thousands of these collections, and have never yet heard a single word of complaint. See page 16 of this catalogue. 


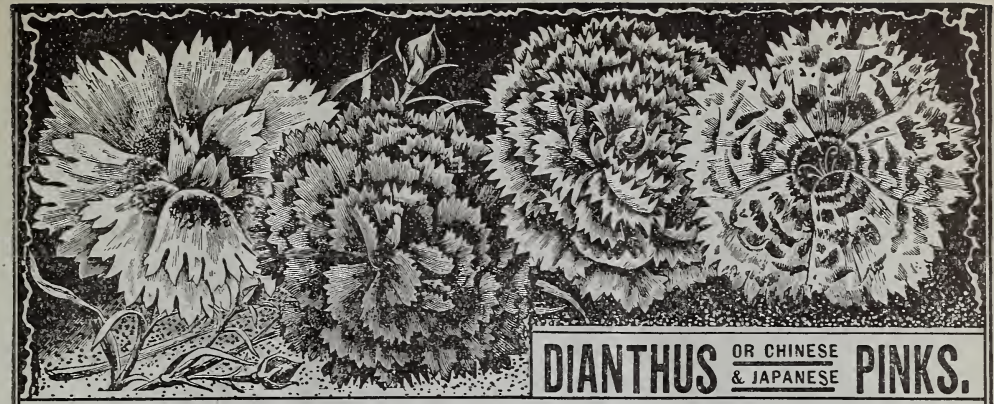

For beautiful cut-flowers, ease of culture, and freedom of bloom the Dianthus is unsurpassed by any other flower.

DIANTHUS, OT CHINESE PINKS.

Superb doubie mixed varieties, incluuing manv colors. strip
spotted and beautifully, frinked Pkt., 100 seeds, 3 cents.

Heddewigil. (Double fapan Pinks, Beuutifut double

Double Diadem Pinks. Large double dark colored

Superb Mixed Dianthus. A grand"mixture, including all the above and many other cholce varieties. 200 seeds, 5 cents.

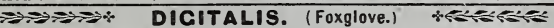

Very popular perfectly hardv perennials three to five ieet high. with rmmense spikes of prettv thim.
le-like spotted flowers. Or easy culture. All the choicest varieties mixed. 200 seods, 3 cents. ble-like spotted tiowers. Or easy culture. All the choicest varieties mixed. 200 s Well known and popular plants that should be in every gurden. Easily grown from seed. Will bloom
the tirst season if started early. Finest single and double varieties wixed. Pkt., 25 seeds, 5 cts.

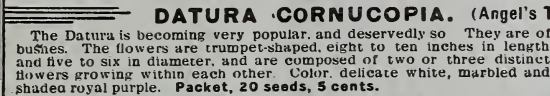

\section{DATURA COLDEN QUEEN.}

A magniticent companion to Datura Cornucopia. Exactly like it in every
respect except in color. which is beautiful golden-yellow $25 s$., $10 \mathrm{cts}$

ESCHSCHOLTZIA. (California Poppy.)

Hardy annuals. growing about a foot high and literally covered with rich yellow single flowers about two inches in

Packet, 200 seeds, 3 conts.

\section{EUPHORBIA.}

Heterophylla-"Mexican Fire Plant" and Variegata-.-Snow on the Mounian both

former turning to a brilliant orange scurlet: two varieties mixed. 50 sęeds, 5 cents.
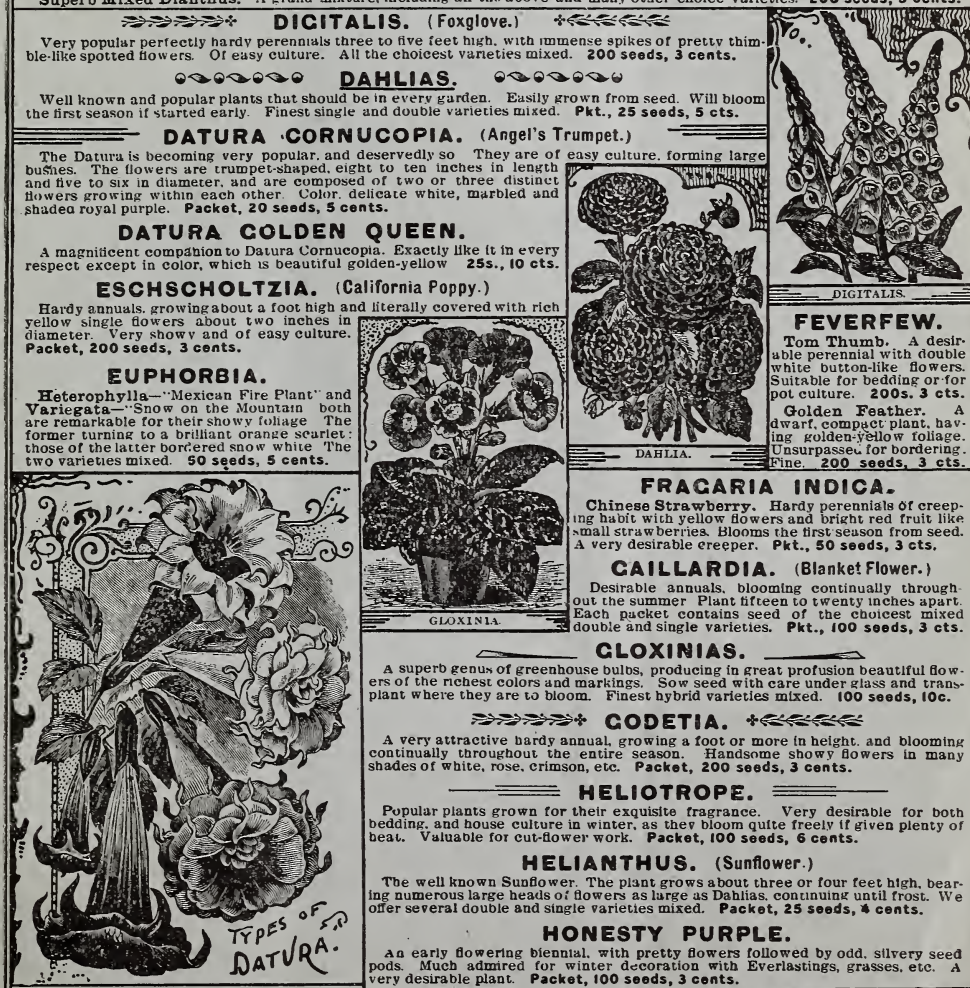

\section{CLOXINIAS.}

A superb genus of greenhouse bulbs, producing in great profusion beautlful to ers of the richest colors and markings. Sow seed with care under glass and tran

$$
\Rightarrow \Rightarrow \# \text { CODETHA. HEसEE }
$$

\section{A very attractive bardy annual, growing a foot or more in height. and blooming} continually throughout the entire season. Handsome showy lowers in many shades of white, rose, crimson, etc. Packet, 200 seeds, 3 cents.

Pupular plants grown for their exquisite tragrance. Very desirable for both bedding. and house culture in winter, as the thower work. Packet, 100 seeds, 6 cents.

HELIANTHUS. (Sunflower.)

The well known Sunflower. The plant grows about three or four teet high, bearng numerous large heads of tlowers as large as Dahlias, continuing until frost. We HONESTY PURPLE. A a early fowering biennial. with pretty fiowers followed by odd. sllvery seed
pods. Much admired for winter decoration with Everlastings, grasses, etc. A

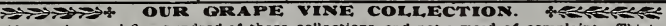




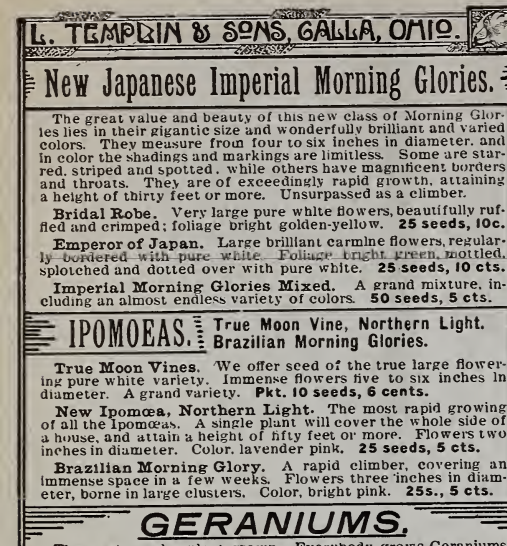

The most pupular plant grown Everybody grows Geraniums and would not know how to get along without them. We ond
seed saved frum an assortment of varieties which should pro-

duce some ehoice new varieties Pkt. 25 seeds, 5 cents.

Apple Scented Geraniums. A very popular plant. Le
delightfully irugrant. Try it. Packet, 30 seeds, 10 cents.

\section{SEEDS, PLANTS \& BULBS BY MALL.-}

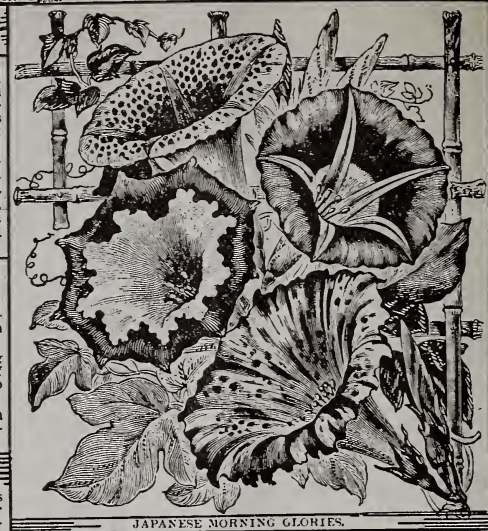

E HOLLYHOCKS.

The Hollyhock in their present state of perfection are one of the most beautiful aud desirable plants for the lawn. The flow
ers are as double as a kose. and embrace all the shades of red,
pink, yellow, crimson, white, etc. Mixed. 50 seeds, $5 \mathrm{cts}$.

pink, yellow, crimson, white, etc. Mixed. 50 seeds, 5 cts.
New Fringed Allegheny Hollyhock. This is a decided im. provement over the common variety. Flowers of immense size
tive to snven inches across. beautifully fringed. having the appearunce of crusbed silk. Claimed to be perp
All colors mixed. Packot, 50 soods, 10 cents.

JAPANESE VARIEGATED HOP.

There is to hardier or prettier climbing vine than the Japan ese Hop, and for quick grow th, resist
it has no equal, Leaves beautifully
white Packet, 25 soeds, 5 cents.

ANNUAL LARKSPUR.

One of the most popular annuals in
cultivation. growing two feet or more

in height and producing showy spikes
of fowers, including white. pink, vlue,

purple, ete. Finest Hyacinth Flower
Stock Flowered. Rocket. New. Emp.
ur, \&c, mixed. 200 seods, 3 conts.

\section{LAVENDER.}

Old Fashioned Sweet. Well knuwn sweet perennial. bearing long spikes of
blue fowers. Fine for in handkerchief

boxes, ete.
Packet, 200 seeds, 5 cents.

Packet, 200 seeds, 5 cents.
Well known and popular annuals,
growing from one to two feet in helight
and producing larte double towers, vel-
low, orange and brown in color. Best
French and A frican varieties mixed.
Packet, 100 seeds, 3 cents.

\$
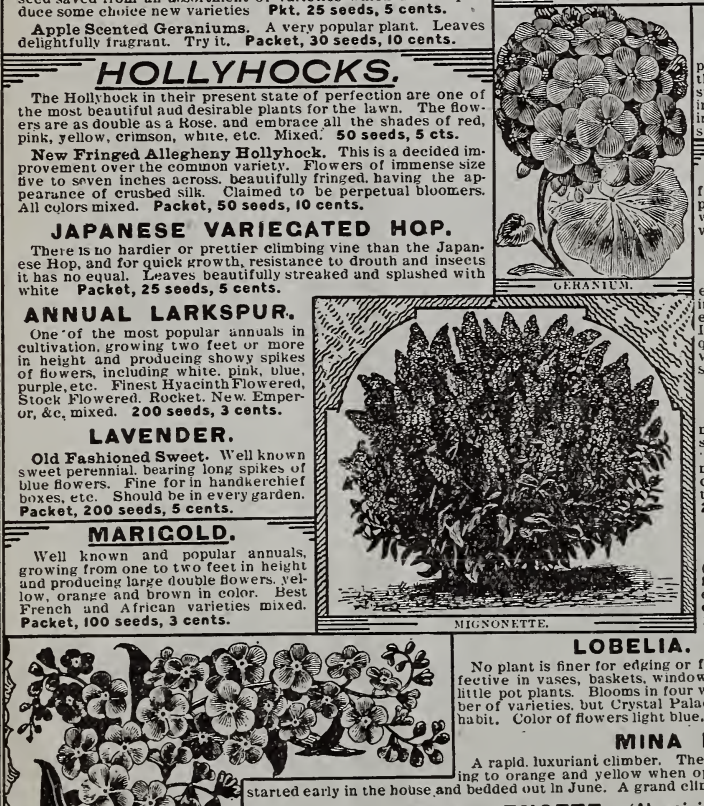

\section{MYOSOTIS.}

Forget-me-not. They are very popular half-liardy perennial plants started early. They succeed best
in moist places, but may be grown in pots if well watered. Flowe
small. lovely blue. $100 \mathrm{~s}$., $3 \mathrm{cts}$.

\section{MICNONETTE.} Everybody knows and admires the
fragrant Mignonette. It is indis-
pensable in all classe of cut-fiower pensable in all elasse of cut-fiowe
work. We offer several choices

MAURANDIA.

Barclayana. A graceful climbin summer. For decorative purpesin summer. For decorative purpes. Packet, 100 seeds, 5 cts.
Park MIMILUS.

\section{Monkey} mental little plants with beautiful -Mimu un ape, from the gaping ceed in the hot sun. but are just the MARVEL OF PERU. Four O' clock. The well known (Four O clock.) A handsome free fowering garden
easy culture, requiring but little
eare, Finest varieties mixed. Pkt., 25 seeds, 3 cents.

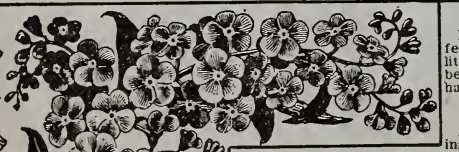

LOBELIA. (Crystal Palace.)

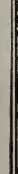

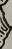

\section{MINA LOBATA.}

NICELLA. (Love In a M'st.)

NICOTIANIS AFFINIS. A popular annual havlng finely cut foliage and cur- $\begin{gathered}\text { Showy. Pragrant, bure white; star-like flowers, } \\ \text { whlch a re produced on upright stalks two feel or }\end{gathered}$

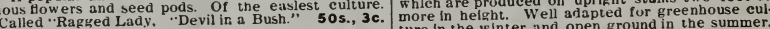
Nemophila. Very popular. Should be in every ture in the winter and open ground re

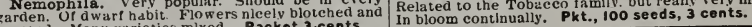


[L. TEMIPLIN \& SONS, GALLA, OMIO. SE SEEDS, PLANTS \& BUBS BY MALL

\begin{tabular}{|c|}
\hline 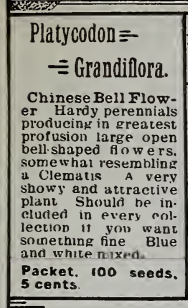 \\
\hline
\end{tabular}
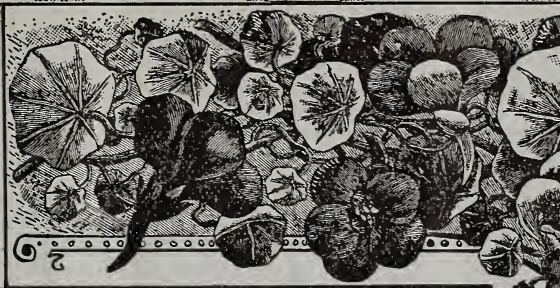

NASTURTIUMS.

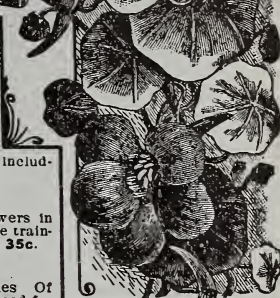

LOBB'S CLIMBING NASTURTIUMS.

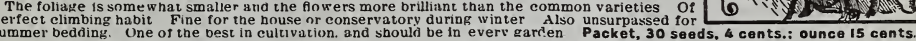

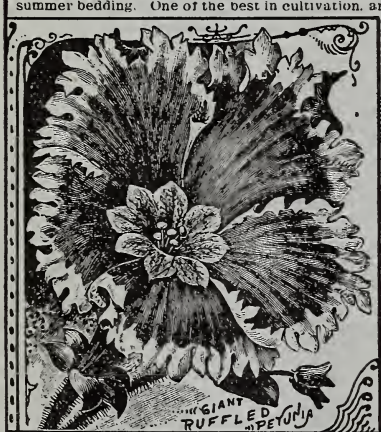

PHLOX DRUMMONDI.
MAD. CUTHRIE'S HYBRID NASTURTIUMS. These originated with a celebruted French specialist and are a decidea ad.
vance over the old type They are of climbing habic. and comprise many odd and brilliant shades of pink, rose, rad, yellow, etc.. many being curiousl, mo
tled. striped, etc. Strong growers and free bloomers 30s., 6c.; oz. $20 \mathrm{c}$.

For a splendid mass of color and constant display the Phlox are unsurpassed They are remarkably profuse nloomers. and a bed of them is a dazzlin

Superb Mixed. Including an almost endless variet 200 seeds, 3 cts.

Double White. Will produce agoua percent. of double flowers $1005.6 \mathrm{c}$.

Nana Compacta. A disunet strain of very dwart. compact pabit Cn-

excelled for pot culture alsu excellent for borders etn
tinct colors-Fire bill. scarlet Snowball white each 100 seeds, 5 cts.

Grandiflora Phlox This is a strong growing class, producing somewhat

they differ but litue from the popular old Drummondi 200 seeds. 5 cts.

STARRED AND FRINGED PHLOX.

A distinci ano very aesirable new class ot these popular annuals, differing
from tne commun Phox in the torm of their flow ers some being star-shaped from the commun Phlox in the torm of tneir flowers some being star-shaped,
others beautifullv fringed beautrfully bordered and striped The seed we
ofter will produce an almost cndless variety of colors and form. 200 . 5 c.

6

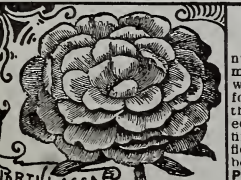
DOUBLE PORTULACCA.

Well know
with immense
mixed varieties

PETUNIAS.

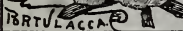
Verv desirable low grow ing annuals of verv eas, culture They
make a tine bed on the lawn and when other plants are perishing
for want of moisture they are in their glory We offer finest mix. nfty per cent, of perfectly double towers This grani tower should Packet. 300 seods, 5 cents

known and popular perfectly nardy sarden ravorltes

PERENNIAL PHLOX.

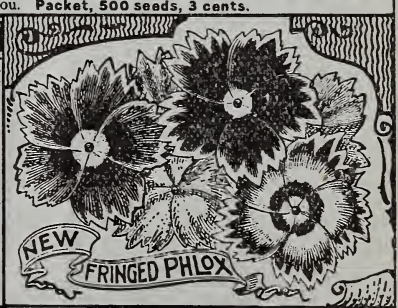

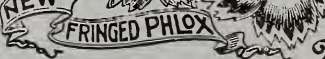

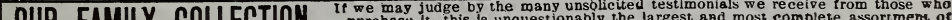

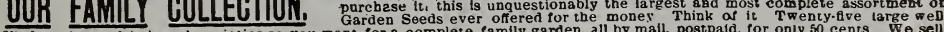
alled packets of just such varieties as you want for a complete family garden, all by mall. postpald. for only 50 cents W $\theta$ sell
thousands of these collections, and have never yet heard a single word of complaint. See page 16 of this catalogue. 


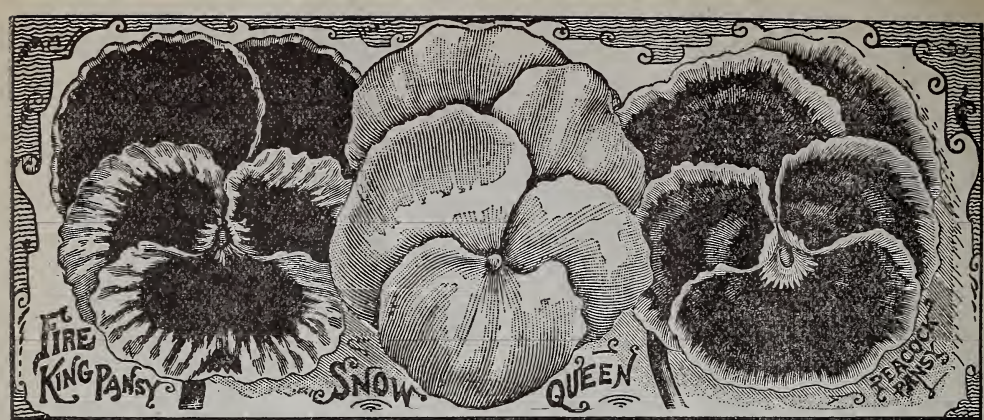

7 HERE is no fow er more popular and satisfactory than a good strain of Pansies A nd there is nothing more disappointing Lnan a poor strain of Pansies We make a specialty of Pansies. al ways procuring the best vhe rever thej are to be had:
mostly from France and Germany where the best Pansies are grown. We will offer separately nnly a few of the most

\section{CIANT BUCNOT PANSIES.}

and remeorated Freneh strain. noted tor their extra large slze tint of red brown and bronze not found in shy other Pansies Very tine Packet, 100 seods, 10 cents.

CASSIER'S CIANT BLOTCHED. An exceedingly the French struin of enormous large size with three to dive blotehes on rich back ground Flowers borne well Packet, 100 seeds. 8 cents.

\section{CIANT TRIMARDEAU PANSIES.}

Remarkable for the extra large size of the flowers. Embracing a great variety of colors and usually huve a dark bioteh

\section{SNOW OUEEN PANSIES.}

Pure satiny white with yellow dot in centre Sometimes faintly shaded near centre with faint blue A favorite variety with many. Packet, 100 seods. 4 conts.

\section{BLACK PRINCE PANSIES.}

Large, rich coal black flowers with a glossy velvety tinish.
fine companion to Snow Queen. Plt., 100 soods, 4 cents.
New Pansy, PRES. CARNOT. A strikingly beautiful new Pansy Flowers of large size, pet-
als pure white, each adorned with a deep violet bloteh. Quite als pure white, each adorned with a deep violet blotch. Quite distinet. This new variety originated rrom the Giant Cassier variety in everv was:. Packet, 100 seeds. 10 cents.

FIRE KINC PANSY.

The three lower petals each have a deep orown-red bloteh with broad. yellow maryin. while the upper petals are of an in.
tense tiery red : hence the name. Quite distinct 100 seeds, $5 \mathrm{c}$.

\section{PEACOCK PANSY.}

A very beautiful Pansy Rich ultramarine olue with narrow white border. Centre purplish crimson, passing to a rich royal purple blotch shading to black Closely resembles a peacocts Packet, 100 soeds, 5 cents.

\section{SWEET SCENTED TUFTED PANSY.} A distinct class of Pansles, being a cross between the Pansy and the Sweet Scented Violet. They are hardier than the ordinary Pansy, grow in tufts, or clumps and are usually quite fragrant. The towers are about two inches in diameter: comprising

\section{"SUPERIOR" "MIXED PFESIES. \\ We have for years been offering this "Superior gracte of mixed Pansy seed. and selling thousands of packets each year (Former price $25 \mathrm{cts}$. per packet.) and hav ture of the best large flowering ists both in this country and Europe, including all the above named varieties. WV believe it to be the most complete mixtur
this season: Packet, 150 soods, 10 conts. \\ " OUR "EXGELSIOR" PANSIES. \\ (1) those desiring a really the strain of Pansies at a nominal cost \\ Azure Blue, Atropurpurea, Alba Marginata. Atro Violacea, Bronze Col cred, Black Blue, Candidissima, or Snow-flake, Golden Yellow. Gold Mar Bin, Havana Brown, Bmperor William, Fawn Color, King of Blacks, Ligh field, Golden Dracon. Silver Edge, Violet; margingd white. Victoria Red, \&e. Price of the above mixture, packet, 150 seeds, 5 cents \\ Ordinary Mixed Pansy Seed. This packet contains a mixiure of rine quality

POJPIES.

New White Swan. A grand variety, forming pretty bushes eighteen lnches high
surmounted with enormous, perfectly double pure white flowers. 200 soeds, American Elag A charming variety Larke double snow
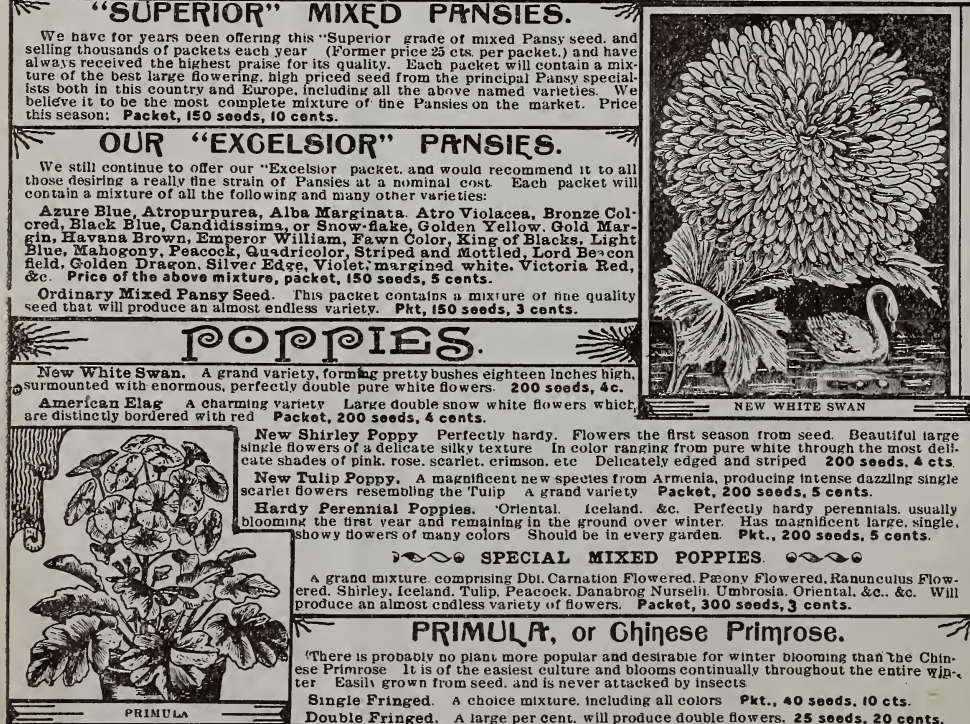

New Shirley Poppy Pertectly hardy. Flowers the first season trom seed. Beautiful targe akle flowers of a delicate silky texture In color ranging from pure white through the most del New Tulip Popp. A magnificent new speeses from A rmenia producing intense dazallng single resembling the Tulip A grand variety Packet, 200 soeds, 5 cents.

Bardy Perennial Popples. Oriental. lceland. \&c. Perfectly nardy perennials. usually 5 the tirst vear and remaining in the ground over winter. Has toagnificent large. single.

\section{$D \rightarrow \infty$ SPECIAL MIXED POPPIES $\infty \propto$}

A grana mixture comprising Dbl. Carnation Flowered. Pæony Flowered. Ranunculus Flow. produce an almost cndless variety uf fowers. Packet, 300 seeds, 3 cents. \&C.. \&c. Will

\section{PRIMULA, or Ghinese Primrose.}

There is probably no planu more popular and destrable for winter blooming than the Chinese Primrose $1 t$ is of the easiest culture and blooms continually throughout the entire wip列

Bingle Fringed. A choice mixture. Including all colors Pkt., 40 seeds. $10 \mathrm{cts}$ 


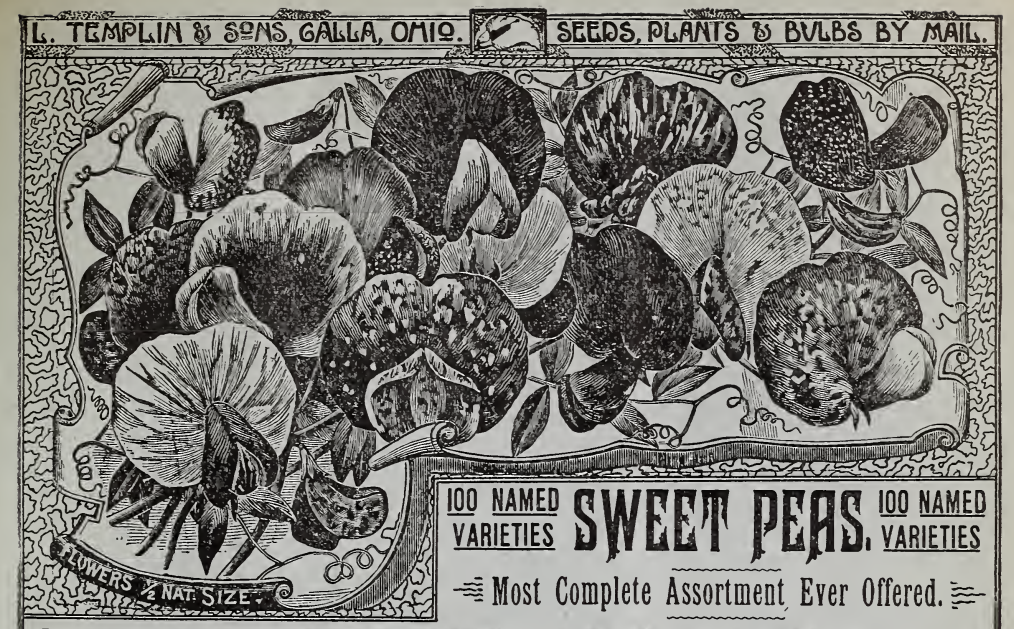

EVERYBODY KNOWS That $S$ weet Peas are the sweetes* and prettiest fower that krows. and we want eversbody to know We take it for pranted that our patrons want the greatest possible assortment of varieties at the teiste texpense. Realizing

\section{One Hundred Choice Named Varieties.} sigbt of British Columbia. to grow us TON OF SWEET PEAS rom the one hundred named varieties ern locality was because the delightfully cool and moistatmosphere is particularly adapted to thelr culture The grandest $\mathbf{S}$ wee Peas we ever sum was in this locality. The bou drv climate of Soubern californla where they are mosuly grown cunnot be coupared with Northern $W$ ashlng ton for growing choice $S$ weet Peas

If you want to grow the finest Sweet Peas in your neighborhood, you will make no mistake by ordering our "100 Varieties Mixed." You cannot procure so complete an assortment from any other seedsmen in the country. For the convenience of those wishing to order in separate colors and shades. we have them put up in separate shades. each shade ur color comprising a mixture of severa
We wll not devote several pages to the descriptlon of all the varieties we offer.

100 NAMED VARIETIES. Each packet will contain 100 seeds-one seed each of the duce a grand display. Price, $10 \mathrm{cts}$. per pkt.; 3 for 25 cts.; 7 for $50 \mathrm{cts}$.

100 VARIETIES MIXED. Each packet will be filled from an equal mixture of the one hun.

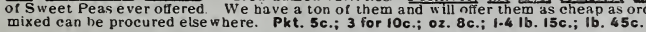
RED, WHITE \& BLUE, An equal mixture of Invincible Scarlet. brilliant red, Emily Hend-

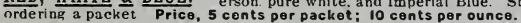

PINK VARIETIES. A complete assortment of all delicate pink, blush and rose colored

RED. VARIETIES. All the best varieties of scarlet. crimson. carmine, claret, etc PURE WHITE VARIETIES. Comprising all the best pure white varieties mixed. LIGHT BLUE VARIETIES. Iueluding all light blue, azure blue, lavender, mauve, etc. BLUE \& PURPLE. Comprising dark blue, purple, maroon, indigo, etc.

STRIPED SORTS. Several choice striped. streaked and spotted varieties mixed.

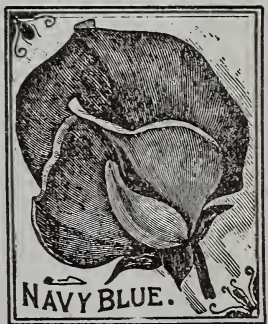

Price of above 6 varieties, packet 5 cents ; ounce 8 cents.; 1.4 pound 15 cents; pound. 45 cents.

ORDINARY MIXED. Good mixture as usually sold by other seedsmen. Pkt. 2 cts.; 0z: 5 cts.; 1.4 lb. 12 cts.; lb. 30 cts

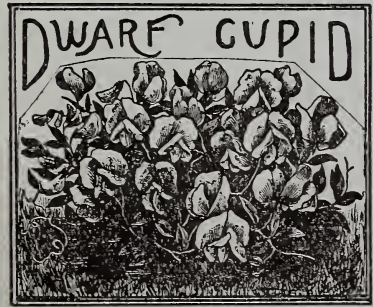

DUCARF CUPID. D

This is the wonderful variety that caused such a sensation two years ago. Imagine a dwartsweet Pea on $y^{6}$ to 8 incbes high, and literally covered with fowers and you can have some idea of its value. We offer two varieties:
White Cupid and Pink Cupid. Price. 5 cents per packet: 15 cents per oz. THE TWO VARIETIES MIXED, PACKET 5 CENTS; OUNCE. 15 CENTS.

DOUBLE SWEET PEAS.

These sweet Peas do not always comedouble Ther usuallv produce about thirzy per cent of double bowers. You will frequently find double and single flowers on the same stem They are very interesting and deserves a place in every garden. Price. 5 cents per packet. 10 cents per ounce.

\section{\# PERENNIAL PERS. $\approx$}

$A$ perfectly hardy and very desirable class of $\mathrm{S}$ weet Peas that die to the ground each autumn and start again the following spring. They grow eight to

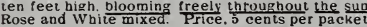

"Our Sueet Peas were eleven fept high Thousands of flowThe finest Sweet Peas we ever raised were grown Imst

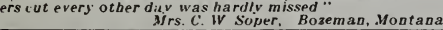




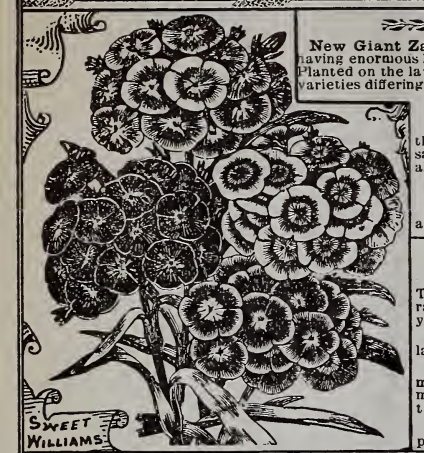

RICINUS ZANZIBARENSIS. WE:-

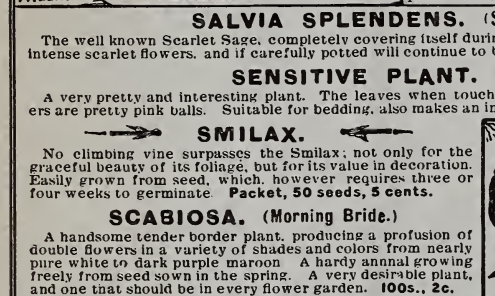

THUNBERGIA.

Black Eyed Susan. A beautiful climb-

ing vine useful for vases, rustic work. or
house culture. Color, white. vellow, or-

VINCA.

Pretty ornawental plants with gloss. $y$

Pretty ornanental plants with gloss,
green leaves and showy fowers an inch or

more in diameter. Suitanle both for pot
culture and bedding Rosea and White wit

VALERIANA.

(Hardy Heliotrope) Show $y$ border plant. or for mixing with shrubbery: grows weli

in any garden soil : does weell in the shade.
Produces large crops of beautiful fowers.

A hardy perennial that blooms the frist
season frow seed. Fine for bouquets and

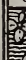
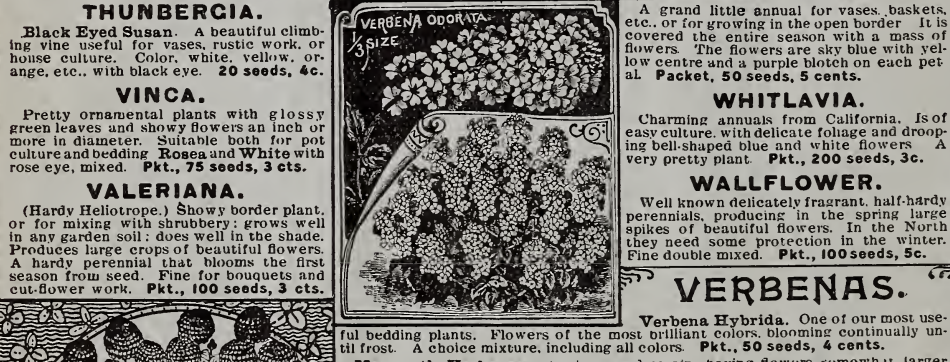

TEN WEEKS STOCKS.

Gilly Flower. These are among nur most snow y and valuable annuals,

They bloom in about ten weeks from seed and continue until frost. colors

Dwarf German Ten Weeks. Finest double
yellow white.
large flowering. including all colors $50 \mathrm{~s}, 3 \mathrm{c}$.
Large Flowering. Pyramidal. Having tm-

mense spikes of perfectly double fowers. pria-

wo inches or more in diameter 50 seeds. $5 \mathrm{c}$.

Perpetual White. (Cut \& Come Agann.) Dbl.
pre white. perpetual bloomer 50 seeds; 5c.

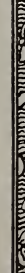
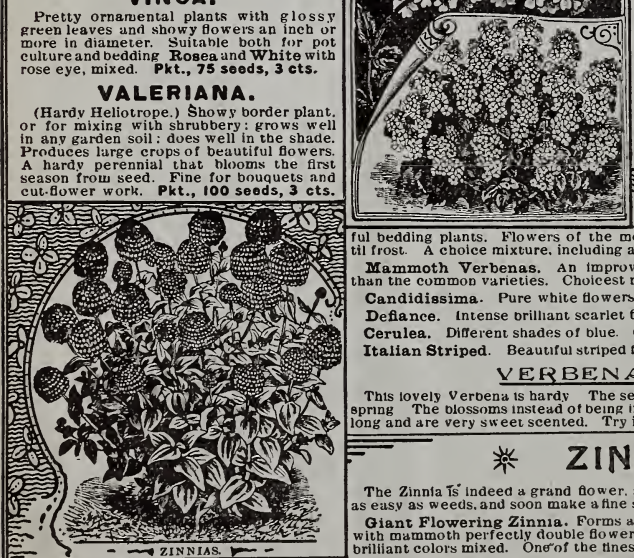

WHITLAVIA.

Charming annuals from California. Is of easy culture. with delicate foliage and drooping bell.shaped blue and white flowers
very pretty plant. Pkt., 200 seeds, $3 \mathrm{c}$.

WALLFLOWER.

Well known delicately fragrant. half hardy perennials, producing in the spring large they need some protection in the winter.
Fine double mixed. Pkt., 100 seeds, 5 c.

\section{VERBENAS.}

Verbena Hybrida. One ot our most use. ful bedding plants. Flowers of the most ortlliant colors, blonming continually un-
tit conts. Mammoth Verbenas. An tmpruved stratn, having dowers sumewhat larger than the cummon varieties. Choicest mixed colors. Pkt., 50 seeds, 6 cts.

Candidissima. Pure white flowers Very the. Pkt., 50 seeds, 5 cents. Defiance. Intense brilltant scarlet fowers. Packet, 50 seeds, 5 cents. Cerulea. Different shades of blue. One of the best. Pkt., 50 seeds, 5 cents. Italian Striped. Beautiful striped tlowers Packet, 50 seeds, 5 cents.

\section{VERBENA ODORATA}

This lovely Verbena is hardy The seed mav be sown in the open ground in early spring The blossoms instead of being in elusters run up into long spikes 3 or 4 inch long and are very sweet scented. Try it Packet, 50 seeds, 3 cents.

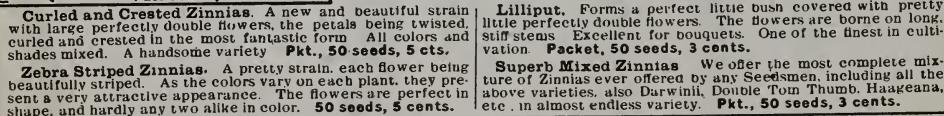




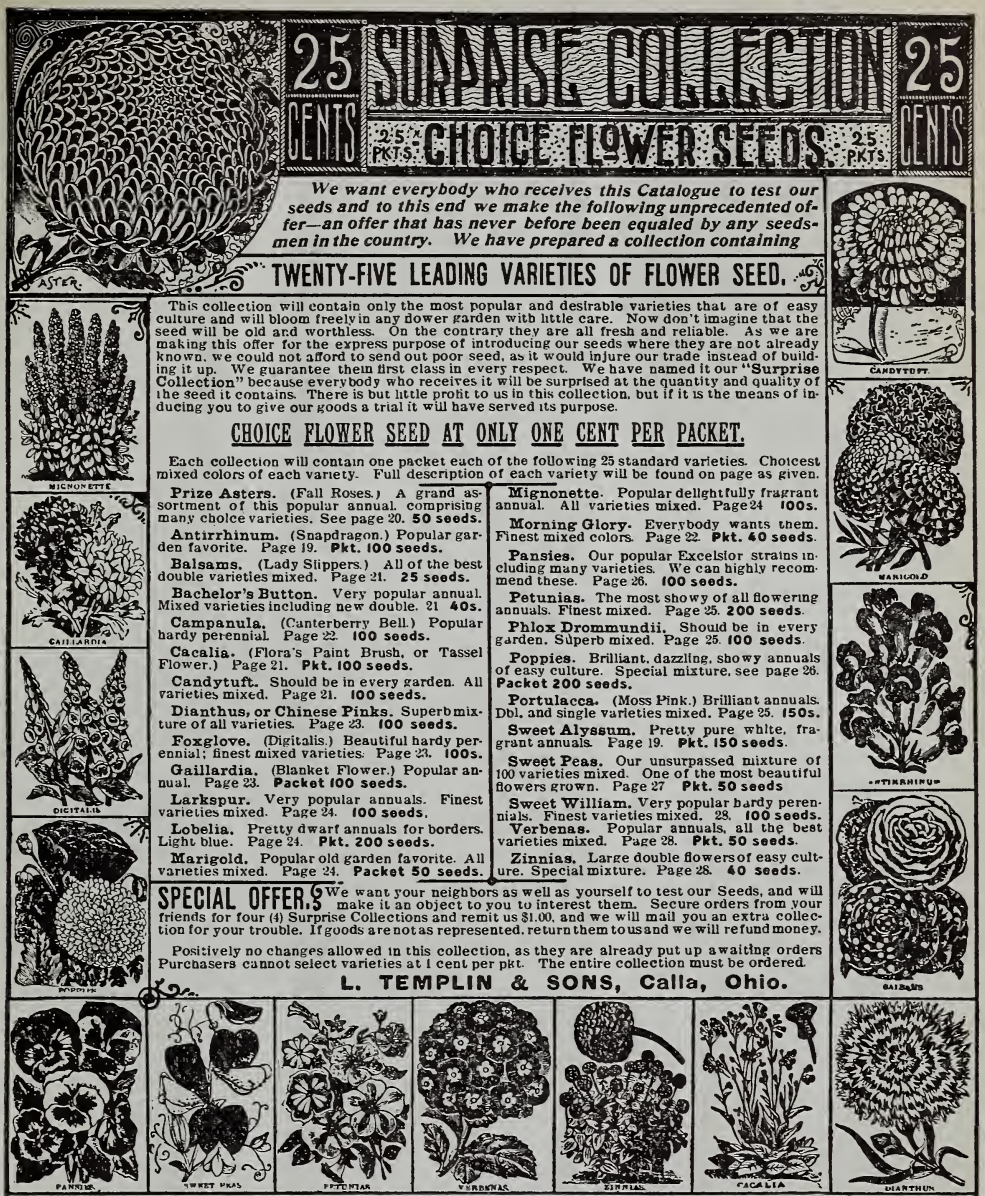

SPECIAL MIXTURES OF CHOICE FLOWER SEED.

The following cullections are put up for the accommodation of those whowish to procure as great. a variety as possible for the least expense. They are care fully prepared from our choicest fresh seeds, and cannot fail to give satisfaction. These packets are lairge and wel Each packet of mixtures will contain more than one thousand seeds.

NPEDDING MIXTURE. This mixture is prepared especially for those who want a bright bed in the yard or garden throughout the season. It will include
such varieties as our superb Balsams, Phlox, Petunias, Popples, Gail. laraias. Marigold. Zivnias and twenty or more other varieties. Price, large packet. 10 cents each : 3 for 25 cents

- C BOUQUET MIXTURE.

In this mixture we will include only such varieties as are mose suitable for cut. flower work, such as Asters. Alyssum, Candytuft,
pianthus Pinks, Mignonette, Forget-me-not. \&c.. \&c. Price. large
packet, 10 cents ; 3 for 25 conts. The four Choice Mixtures, one of each for only 30 cents, postpaid.
CLIMBING MIXTURE. 2\% Just what you want for porches, verandas, etc., or covering old rences, walls, etc, , thcluding Ipumceas, Morning Glories, Cypress
Vines, $S$ weet Peas, Dolichos, Thunbergia; \&c. There is no collection of climbing vines that surpass this. Price. $10 \mathrm{cts}$

\section{PERENNIAL MIXTURE. \%}

Every garden sbould contain an assortment of hardy perennia flowering plants, and in no other way can you procure them so easily. Each packet will contain a mixture of all the standard varieties of hardy perennials. Are among our most attractlve and

\section{EVERLASTINGS, or STRAW FLOWERS.}

These are tndispensable for working into winter bouquets, as they retain their forms and colors for years. The towers should be cut before fully open. tied in small bunches and hung up tn a dark room
They make beautiful Holidas presents when male in to bouquets 

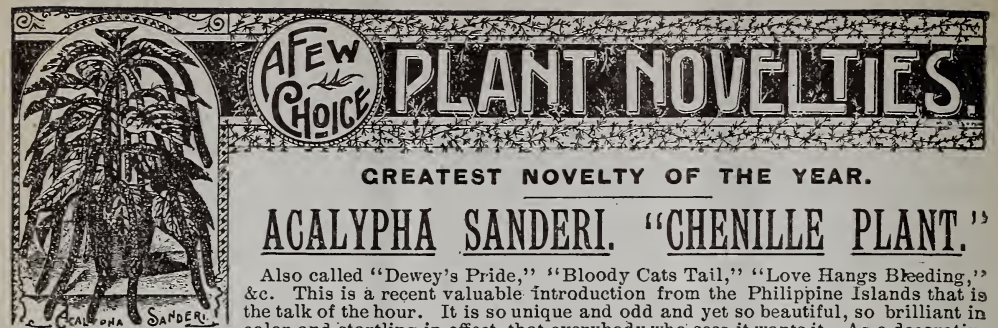
ACALYPHA SANDERI. "CHENILLE PLANT."

Also called "Dewey's Pride," "Bloody Cats Tail," "Love Hangs Bkeding," \&c. This is a recent valuable Introduction from the Philippine Islands that is the talk of the hour. It is so unique and odd and yet so beautiful, so brilliant in color and startling in effect, that everybody who sees it wants it. As a decorative plant in any situation it is unsurpassed; whether it be upon the dining table, in the window, in the conservatory, church, or house, it amply fulfills every requirement. It is of the easiest possible culture, being a wonderfully rampant grower and a very profuse and continuous bloom. Its marvelous flowers consist of beautiful, fluff y pendulous tail-like blossoms from twenty to twenty-five inches long, of a soft, glowing crimson-scarlet, which gracefully trail and droop amid the bright green foliage with a delightful effect. It blooms unceasingly the whole year through and with only ordinary care. Its beauty is of too peculiar a style to be adequately described. Must be seen to be appreciated. Price, 20 cents each.

\section{PINK ABUTILON.}

Enfanta Enlalia. Unquestionably the most beautiful Abutilon in cultivation; of upright compact habit. Elowers unusually large, opening out wide with nicely cupped petals. Color, clear delicate satiny peach blossom pink. Entirely distinet in form and color. Some forists gre sending out an inferior pink varietw under the above name. The
genuine. Enfantas are always scarce. We have a nice stock this seagenuine.Enfantas are always scarce. We
son. Price, 15 conts each; 2 for 25 conts.

> New Dwarf Variegated Abutilon.

Savetsii. A valuable new variety of dwarf, compact habit. Foliage deep green with a broad, variegated, creamy white border; many of the leaves being almost pure white. others white with small green
blotch in the centre. A rare and beautiful variety. Price, 15 conts. Tro

\section{ASPARAGUS SPRENGERI.}

Unquestionably the most popular new plant introduced in many years. Probably no plant ever grew so rapidiy into public favor because none embrace so many valuable qualities. It is especially useful to grow as a pot plant in vases, window-boxes or suspended baskets. A vigorous
grower the whole year round, producing sprays four or five feet long grower the whole year round, producing sprays four or five feet long.
of fresh bright green feathery foliage. Useful for bouquets. wreaths or spravs, remaining perfect for weeks after cutting. Admirably adaptor sprays, remaining perfect for weeks after cutting. Admirably adapt-
ed for house culture, withstanding the dry atmosphere and growing ed for house culture, withst
freely with ordinary care.

The accompanying illustration is 'from " a photograph of a specimen plant now growing in our houses. and will give an idea of its graceful drooping habit. This plant is the means of selling hundreds of small plants as almost everybods who sees it wants one like it. We have each; 3 for 25 conts. Large 3-inch pot piants, 25 cents.

"5" aSPARAGUS PLUMOSUS NANUS.

\section{(C,ACE FERR.)}

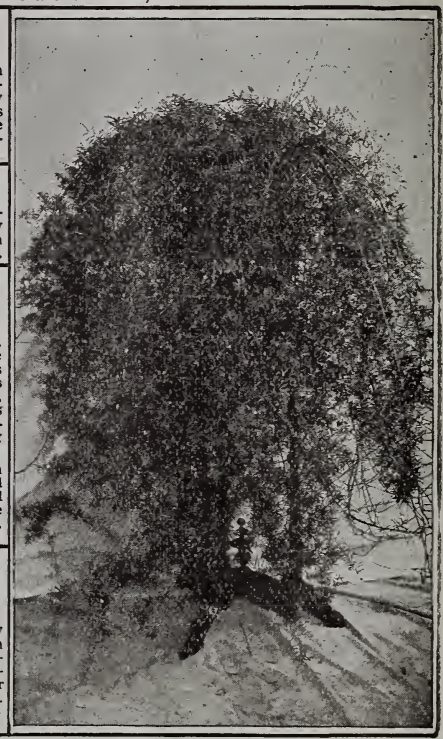

A grand décorstive pot plant with bright greèn, very fine, gracefully arched, plume-like foliage. The fronds or plumes are $t w e l v e$ to fifteen inches in width. It is of eass culture, succeeding under almost ans con ditions. It is to a great extent taking the place of Smilax for decora tive purposes; its foliage being finer than the finest fern and lasting $f$ Must be seen to be appreciated. Price, strong 3-inch pot piants, 25 conts each; 2-Inch pot size, nice plants, 15 conts.

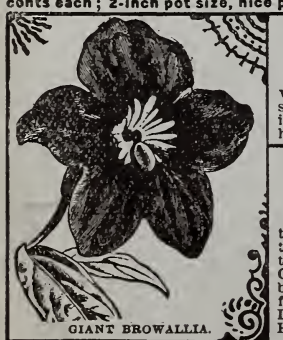

\section{New Giant Browallia.}

A most valuable addition to our list of summer-blooming plants. Most people are famillar with the old form of Brow allia. and would scarcely recogpize this grand new variety as of the same family. The fiowers are indigo blue, fully two inches across, and cover the plant when in bloom. Invaluable for summer beds of thowers or for pot plants in the winter for greenhouse and window garden. Price only 10 cents each.

\section{... Mr. THE ThOMOUS $\$ 30,000$ CARNATION.}

This wonderful new Carnation is attracting more attention than any other variety ever in. troduced. It was originated by Mr. Peter Fisher, of Ellis, Mass, and ereated so much in serest wherever exhibited that the entire stock was sold for the fabulous price of thirty thousand dollars, and so sure was the purchaser that he had the largest and most perfect Carnation in existence, that he offers.tive thousand dollars to the person who will produce a better one. The fowers are claimed to be four inches in diameter and of the most perfect form and habit. Color. clear beautiful pink. If you wish to be up to date order the ramous Lawson Carnation. Our stock is direct from the originator and guaranteed to be genulne.

\section{TWO CHOICE NEW CANINAS.}

President McKinley. A fine new Canna. Color, brilliant President Cleveland. Claimed io. have originated on the crimson with scarlet shadings; of robust, compact babit, grow. Wnite House grounds at Washington. Is probably the tinest ing only about three feet bigh. Trusses are large and held well bright searlet Canna to date. A strong healthy grower 4 to 5 bove the deep green follage. Glaimed to be a decided improve- feet high and a most profuse bloomer. Flowers of immense ment on all other crimson Cunias. Price, 25 conts oach. 
-...NEW GEPANIUMS... _

\section{DOUBLE VARIETIES.}

Grand Dutchess Olga. A entirely new and distinct type. Might be called Double Mad. Bruant. Flowers and truss large, perfect In form. and presenting a beautiful combination of colpetals bright rosy carunine. - Price, 20 cents each.

Royal Purple. A grand Geranlum that should be ln every collection. A strong grower bearing immense hrusses of larze. perfectiy double towers. Color. rich dark majenta purple. One of the most distinct and attractive rarieties that we grow Price, only 15 cents each; 2 for 25 cents.

The set of above four cholce new varieties for only 50 cents.

S.

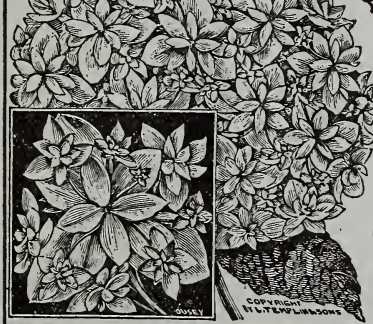

In this new Hydrangea we have one of the most distinet and attractive novel ties to he found. It is of rewarkably free flowering babit, producing large clus light pink in color when tirst open, becoming darker as they increase in age. The most interesting and attractive feature however, is the perfect douhle tittle forets that are produced around the origlnal fiower. in what might be termed "Old Hen and Chicken siyle. The accornpanying illustration whlch give an ldea of its peculiar and interesting habit. If you want sometbing dis. tinct and attractive that your neighbor does not posess, order one these New Double Hydrangeas, Price, 35 cents each.

\section{Russelia Elegantissima.? GRAND NEW BASKET PLANT.}

A verv striklng semi-traillng plant, especially adapted for hanging baskets. vases, w indow hoxes, etc.. when a delicate graceful effect is sought. The plant Is of slender arcbing and drooping habit, throwing out long slender branchlng spikes 2 to 3 feet long which are literally covered with brilliant coral-red florets. Will yrow plants 3 to 4 feet in diameter that looks like a shower of delizate coral-red blossoms, the efect being unique and pleasing One of the most sat.
isfactory piants extant. Of easy culture requiring only ordinary care. $10 \mathrm{cts}$.

\section{NEW HARDY "SWEET MAY" PINK. sis White Witch. 2i}

EverThods knows and admlres the fragrant Hardy Garden Pinks of our grandmotner. gradens, and will therefore appreciate this valuable new variety it is perfectly hardy. forming compact clumps or mounds a foot or more in diameter and 5 or 6 inches bigh Unsurpassed for bordering beds the pretty cumpact hght hluisb-green foliagc forming tinted pink beautifully laced and iringed and delightfully tragrant The plant completely covers itself with a mass of flowers in June $A$ grand plant for cemetery planting. Shuuld be in evers garden Price, 10 cents each 3 for 25 cents; 7 for 50 cents.

\section{"G" New Variegated Salvia.}

Aurea Maculata. This is unquestionahly the most desirable Salvia ever introduced. $1 t$ is a sport from Marmorata Nana, having the beautiful mottled and striped llowers of that variety. but its most attractive feature is in the foliage whic:h is dark green, regularly blotched and marbled with golden+yellow. Iuagine a plant with dark green and golden-yellow mottled fuliage. surmounted with numerous spikes of scarlet and wbite
flowers and you $w$ ill have some idea of its value as a decorative pladt for tbe garden luwn Price 15 cents each; 2 for 25 cents: 5 for 50 cents.

\section{פ़ "New "Baby" Primrose.}

A most delicate ehaste little plant that Is just now attracting mucn attention on ac. count of its fairy like delicate flowers on stems six to eight inches high The flowers are a delicate lilac rose color with yellow centre, some what resembling the popular Forge
menot or Myosotis and are admuably adapted for bouquets and other cut-flower work. It is of the easiest culture, growing freely and bloomlng cootinually under ordinar reatment This is a new plant. something that your neighbors will not have Try to.

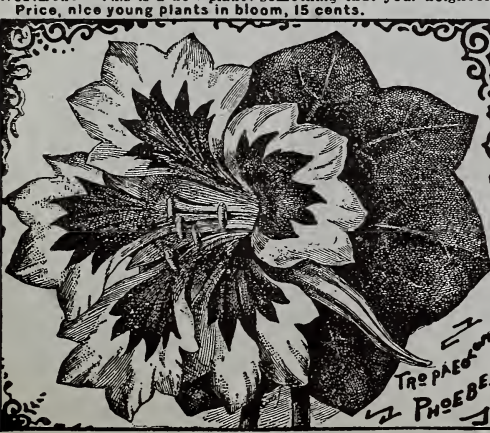

TROPAEOLUM PHOEBE. Na sturtium.

A most attractive and deliciously scented variety. produclng throughout the winter and summer season beautiful towers of a deep golden yellow color with a rich crimson feathered blotch in each segment; outer edge notched or scolloped, the whole torming an exquisitely shaped blossom, admlred by all, and a decided improvement on all existing varieties in this plass. A free and vigorous grower. When in the height of parti-colored lowers can he cut for decoration 8 to 10 feet long Grand acquisition as a trailer in the greenhouse or conserv

\section{"EXQELSOR PLANT FOOD."}

If sour plants look sickly or do not grow and bloom to gour a tisfaction. try a package of our Excelsior Plant Food and

You will be surprised at the result.

It produces a healthy grow th and an abundance of flowers, is perfectly odorless and is easily applied by desolving in 25 cts. per p'k'g. sufficient for 20 plants 3 months. 


\section{Dur Popular 50-Cenl Collections.}

The following collections have been arranged for the convenience of those who do not care to take the trouble of making their own selections. We reserve the right in everv case to select tbe varieties, but will in every instance select a good assort went. In fact you are very liable to secure the very besi varieties for tbe reason that we always endeavor to grow the best varieties in tbe largest quantities. and these collections are flled from varieties that we have in quantity. For convenience in ordering and tilling the orders we have arranged the collections by numbers. When ordering give both
number and name of euch collection wanted. Unless otherwise stated each plant will be carefully labeled.

5 - All collections carefully packed and forwarded to destination, by mall, postpaid. E-

No. 1. Everblooming Roses.

Thirteen choice named varleties, strictly our selection, no two allke. Price oniy $\mathbf{5 0}$ cents, postpald.

No. 2. Hardy Perpetual Roses. In No, $z$ collection we include only perfectly hariy Roses Ejght cholce named varietles, our selectlon, for 50 cents.

No. 3. Polyantha \& other Roses. Five choice variecles of Polyantbas. two Hardy Climbing. two Moss and one Rambler Rose, all labeled, for 50 cents.

No. 4. Combination Rose Col. One of the most popular and desirable collections we offer Wach collection will contain four Monthly Roses-red, pink, ye low and whlte: two Poly untha Roses-pink and white: two Ha Rambler Rose, our selectlon of varleties, all for 50 conts.

No. 5. GERANIUMS. The most popular plants. This collection will contain ten
choice named varietles, 5 double and 5 single, all different, and earefully labeled for only 50 cents.

No. 6. Bedding Geraniums.

Just what you want for a brillant bed on the lawn. A grand assortment of double und single varieties. our selection. not la beled. Purchaser may state eolors preferred. 13 for 50 cts. uy mall. By express, strong plants. $\mathbf{\$ 3 . 5 0}$ per 100 .

No. 7. Chrysanthemums.

A grand assortment including tbe best show varieties, by mail postpaid, our selection, named, 12 for $50 \mathrm{c}$.: not named is. $20 \mathrm{c}$

No. 8. CARNATIONS.

If there is any one collection that we can recommend as spec fally tine it is this collection of beautiful fragrant Carnatlons. By refering vo page $3 \pi$ you will note that the collection wi contuin the very best new and standard varietie.
Jabolod variotios, or 13 not named for 50 conts.

No. 9. Carnations \& Hardy Pinks.

This" grand collection contains six beautiful (Yrnations and slx Hardy Sweet May Pinks. all named, fur 50 cents.

\section{No. 10 FUCHSIAS.}

The most graceful flower grown. A grund assortment of qouble and single varieties Six double and six sinkle for $50 \mathrm{c}$.

No. 11. BEGONIAS

Begonias are amoni our most beautiful and desirable pot No. 12. Brilliant Coleus.

The most popular and show y foliage plants grown. Ten choice varieties, not labeled, for 50 conts,

No. 13. GLADIOUI.

Nothing we offer in this catalogue is more satisfactory for bedding than the Gladioll, und nowhere can you procure a tiner sssortment. 25 cholce blooming bulbs for 50 conts.

\section{No. 14. TUBEROSES.}

These lovely flowers are now so cueap that everybody can af.

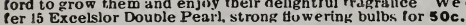

No. 15. GLOXINIAS.

Ten blooming bulbs. chricest mixed varietles of this lovely flower, postpald for only 50 cents.

No.16. Tuberous Begonias.

Tbis is one of the most desirable collections in the entire list. Everybody is delighted with them. For full particulars see

No. 17. POT PLANTS.

In tbis collection we select only such plants as are best adapto ed for pot culture in the house Ten choice varieties. $50 \mathrm{cts}$,

No. 18. BEDDING PLANTS.

Comprising an assortment of plants suitable for planting in the garden, or for a bed on the lawn. Ten varieties assort' $d, 50 c$.

No. 19. BASKET PLANTS.

Thls collection contains plants of a drooping or trailing habit. Jusi what you want for a cboice hanging-basket. Will include one of the celebrated Asparagus Sprengeri in this collection. Ten varieties for only 50 cents.

No. 20. Vase Collection.

Containing ten plants suitable for fllling a vase, including a nice centre plant. and the beautiful new Russelia Elegantissima. A very desirable collection. 50 conts.

No. 21. Decorative Plants.

Comprising 1 Latania Palm. 1 Kentia Palm, 1 Pandanus Utilis, Dracena Indivisa. 1 Grevilla, or A ustralian Silk plant $50 \mathrm{c}$.

No. 22. Cemetery Collection.

1 A chilleu Toe Pearl. 1 Deutzia Gracilis. 1 Hardy Hydrangea, Pink. White Witch.

23. Ornamental Foliag'd Plants. 2 heuntiful Coleus.? A calyphas; I Achryanthus. 1 Maranta Massingeana, I Fancy Leaved Geranium, \& Euonymus Japonica A urea, all for only 50 cents, postpaid.

No. 24. Climbing Vines.

¿ Passion Vines I Dutchman's Pipe, I Parlor Ivy, 1 New Thun berzia Harrisii I Smilax, 1 Asparagus Tennuissimus, $50 \mathrm{cts}$.

No. 25. Beautiful Ferns.

This collection contains six beantiful rarieties including the celebrated Sworc Fern. Silver Fern. Nephrolepsis Cordata, \&c.. 6 for 50 cents. postpaid.

No. 26. Hardy Shrubs \& Vines. Eigbt cholce varieties of hardy shrubs and vines for perma. nent planting on the lawa. Eight named varieties for 50 cts.

No. 27. PANSIES.

Twenty-five.plants grown from seed of the finest large show varieties. Twenty-tive, by mail, for 50 conts.

\section{Combination Collections.}

No. 28.-2 Monthly Roses. 3 choice Geranlums. '3 beautiful show Cnrysunthemums. 2 Frayrant Carnations, and 2 graceful Fuchsias, : 111 for $\mathbf{5 0}$ cents.

No. 29. -2 beautiful Chlnese Hibiscus, 2 Lantanas, or Shrubby Verbenas. 2 Frugrant Heliotropes, 2 choice Hydran. geas, wbite and pink. and 3 Salvias. 50 conts.

No. 30. -2 Double Geraniums, " Single Geraniums, 2 Fancy Leaved Geraniums, "2 Fragrant Geraniums, and

No. 3r.-Bulbs. 3 Excelsior Pearl Tuberoses, 3 choice Gladloli, 1 Calla Lily, 1 Spotted Calla. I Gloxinia, I Tuberbretias, all for onls 50 cents.

\section{\$1.
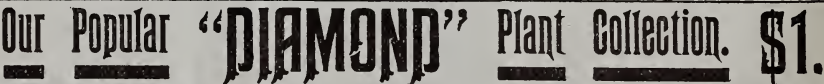

We want evervbody who receives this catalogue to see some of our plants, and as a special inducement to gou to give us tial order, we make this remarkable offer. Positively no change can be made in this collection.

1 Beautiful Now Asparagus, Sprengeri.

1 Fine New Russelia Elegantissima.

1 New Climbing Nasturtium, Phobe.

1 New Bouganville Glebre Sanderiane.

1 New Ageratum, Princess Pauline.

1 Fragrant Cardamon Plant. (Ammomum.)

1 Australian Sillk Oak. (Grevilla.)

1 Beautiful Chrysanthemum, The Queen.

- New Tea Rose, Maman Cochet.

1 Fine Chinese Hibiscus.

1 Eragrant Carnation. Wm. Scott.

1 New Aureole Geranium, Mad. Braant.

1 Crape Myrtle.

1 Beautiful Sword Fern.

1 Pure White Hydrangea, Thos. Hogg.

1 "Old Fashion" Hardy Sweet May Pink.

l Japanese Polyantha Rose

1 Beantiful Fuchsia. 


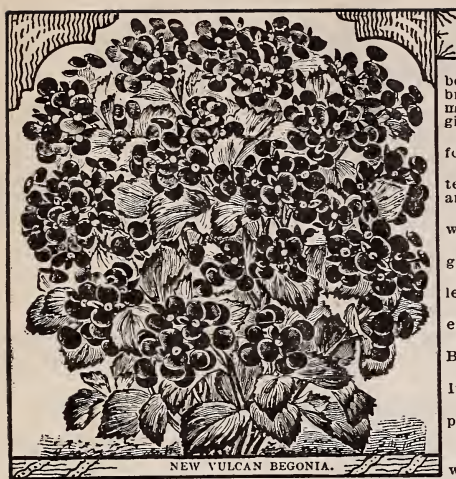

FLOWERING BEGONIAS. This is one of the most popular and interesting classes of plants. The
beauty of the foliage combined with their graceful drooping flowers. brilliant colors and free flowering habit tend to make them one of our give a very brief desc ription of each variety.

Alba Perfecta. Closely resembles Rubra in style of growth and foliage. Flowers pure white. Price, 8 cents each.

Argentea Guttata. Purple bronze, oblong leaves beautifully spor Alvers white, under surface of loliage bright red. Angel's Wings. (Compta.) Bright green long wing shaped leaves, with simson. Very desirable. 8 cents.

Berthe de Chateaurocher. Strong grower: cural red flowers in

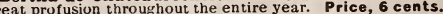

Diadem. Distinct and beautiful. Large green serrated rex-like In plow. Insed salmon. Fine. Price, 8 cents.

Tetallica Very popular. Velvety metallic foliage with dark veins, (1)autiful panicles of delicate pink plush-like flowers. 10 cents.

Multiflora Hybrida. Small foliage. Pretty drooping pink flowers. It makes a very handsome specimen. A profuse bloomer. 6 cents.

Nitia Alba. Strong grower. Glossy green foliage and immense Palmata. Or upright habit. Distinct large Palm-like foliage. I2c. Pres. Carnot. A grand new Begonia. Robust habit: large foliage Robusta. Strong upright habit: coral red flowers in grea
A very desirable variety in every respect. Price, 6 cents.

Rubra. One of the most popular glossy green. shield
lowers are brignt scarlet rose. Price, 8 cents each.

Sanguinea. Very show y. large, glossy rich olive green. leather
toliuge, under side bright crimsun. Very desirable. Price, 8 cents.

toliuge, under

Sandersonii. (Coral Begonia.) Coral red dronping flo
deep green leaves. Always in bloom. Price, 6 cents each.

Thurstonii. A grand Begonic. Large metallic green foliage

Vernon. Very pupular. Glossy rreen foliage; buds deep red. openi

to bright rose. Always in bloom. Fine for bedding. Price, 6 cents.

Vulcan. (New.) In the style of Vernon. but having
blood red filowers throughout the season. Price, 8 cents.

Weltoniensis Rosea Very popular. Delicate pink fowers in the greatest profusion. 'The plants are of tine form. Price, 6 cents.

Wettstenii. Similar to the Rubra. Protably the largest panicles of any variety; Color, bright coral red Very tine. Price, 8 cents.

\section{O ${ }^{2} \mathrm{R}$ RX BEGONIAS.}

This class of Begonias are grown exclusively for the great beauty of their foliage. which is very larke and remarkable for its rich and varied colors and markings, some of which are truly wonderful. They are much used for pot culture or wardian eases. They delight in a rich open soil
and sharp sand. They dislike brizht sunshine and a dry atmosphere, hence should be grown in a moist, shady situation during our hot w eather.

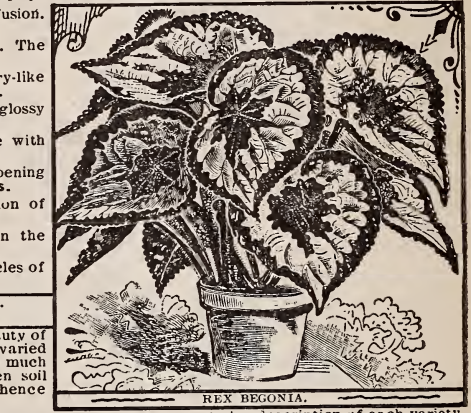

Our stock comprises all the best new and old varieties. Owing to the limited space we cannot give description of each varipty. 濚 TUBEROUS ROOTED BEGONIAS. 落

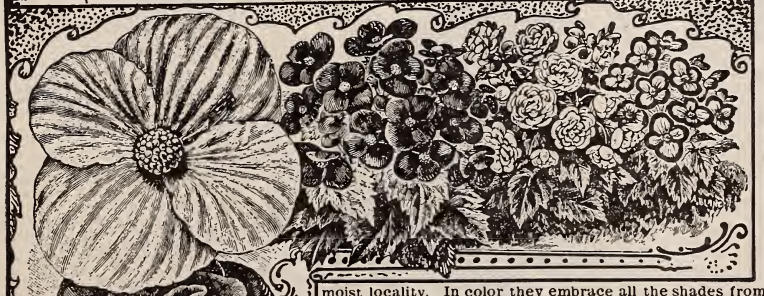
O class of plants attracts
as un ch attention at
present as Tuberous Be-
gonias. Thev have lung been considered one of the ers in Europe, but it has onlv recently beeome known that grown here, They are of the easiest culture and may be ded in the open ground, We know of nothing that excels in beauty a well grown plant pot. Water freely and keep pot. the wind will not strike them. When planted in the open

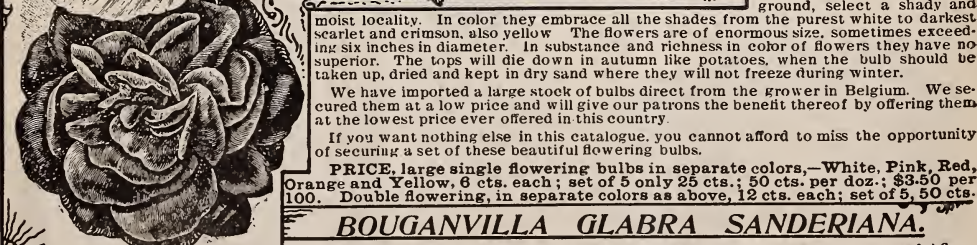

$\approx$ BOUGANVILLA GLABRA SANDERIANA. No plant attracts more attention: eversbody wants to know what it is. We continuallv cut great bunches of flowers and the more we cut the more it blooms. It is ivonderfully viporous, rapid grower, with dark glossy green foliage and great panicles of peculiar but showy flowers. Their beauty lies in their show y bright rosy-crimson colored bracts enclosing small creding white witing so lonv in perfection and produced in such wonderful profusion. Price, nice plants, 15 cents oach. 

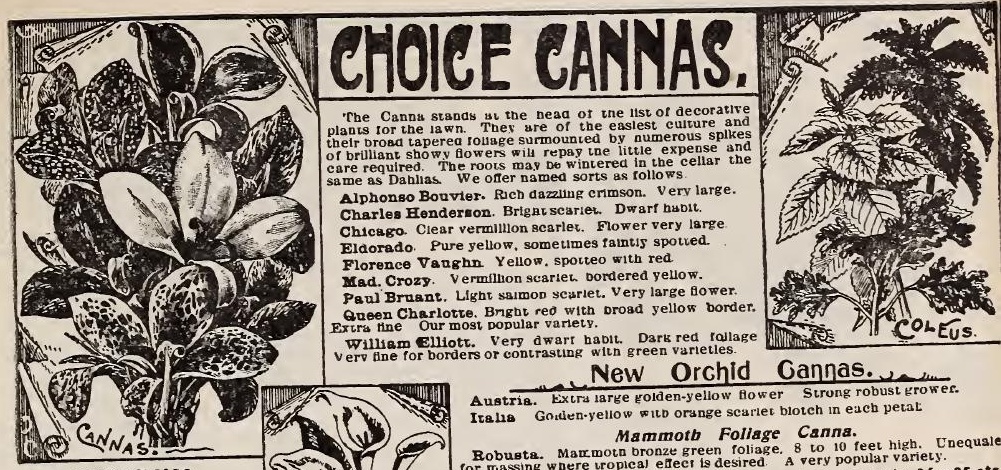

CESTRUM.

(Night Blooming Jasmine.) Producing small inconsplcunus. very fragrant fow ers in great proche whole garden in the evening Goum weather in sprns 6 cts Gentaurea.

(Dusty Muller.) Pretty white

collage plant. excellent for eding
beds: very ornamental when grow as a specimen
plant Fine for centre of hanglng baskets. 5 cts.

$$
\text { ...COLEUS... }
$$

Very beautiful and popular plant. Highly prized for the brilliancy and beauty of their foliage. Suit able for pot culture or hedalng whe oder abvel of beauty in the varlety and richness of their color ings They require a very warm room to succeed in winter Belng somewast teider the sher al aot be ordered until wew danger of trost $1 \mathrm{~s}$ pust
tich solt Prico, 5 conts oach.

\title{
CYPERUS ALTERNIFOLIA.
}

(Egyptian Umbrella Plant.) A splendid plant of the Rush family, throwing up stems about two reel. hgh surmounted with a whor of also desirable

an the aquarium Fine for the centre of vases and
banging baskets of very easy cuiture, requiring conslderable moisture 6 cts

\section{Fancy Caladiums.}

Tnese remarkably heautlful follage plants are of great value for decorat. ine conservitories and window boxes They delight in a warm moist at wos phert When properly treated theo are of the tasiest culture not stand cold weather Ury them out in October and winter in a warm drv place We orcents each; four distinct named varieties for 50 cents.

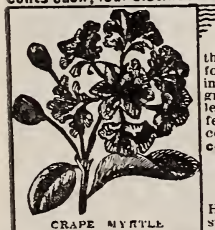

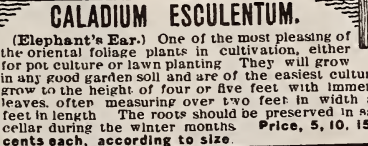
Grape Myrtle.

\section{New Orchid Gannas. \\ New Orchid}

Mammotb Follage Canna.

Robusta mant $r$ massing where tropical efleet is desired. A very popular variety. $25 \mathrm{cts}$ for 50 cts. Strong 1 in. por piants. 15 cts.; 2 for -25 cts.; 5 for 50 cts. Seedling Canbas. uce some grand vaneties will bloom racely the first, yeur, $\$ 3.50$ per 100 2. $2 f^{2}$ Calla Lily.

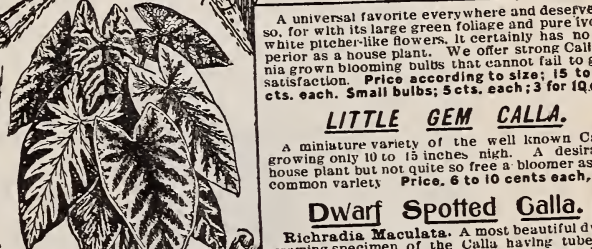
Richradia Maculata. A most beautiful

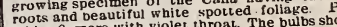
whice flowers with violet throat. The bulbs sh

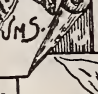

be kept in a warm, dry place.
ine winter. Price, 5 cents ea
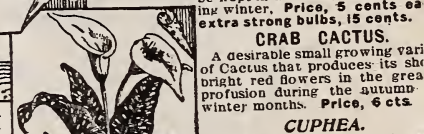
CUPHEA.

(Cigir Plant.) A populur blooming pot plant. With sca

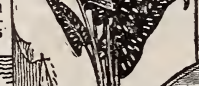

(a)

\author{
.
}




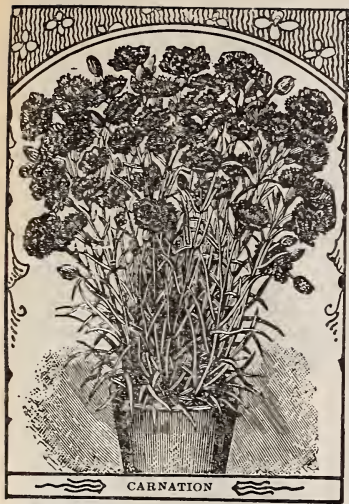
BEAUTIFUL $\triangle$ FRAGRANT CARNATIONS.

The fragrant perpetual blooming Carnation is unquestionably one of the most satisfactory plants grown. For the garden in summer and for pot eulture in the house during winter they have no equal. They are more largely grown by florists to supply cut-flowers during winter than any other class of tlowers. Their brigh colors, delightful fragrance and perpetual blooming qualities should induce every body to grow them. The following are among the best varieties grown, and we

Price, purchaser's selection, named, 6 cts, each, not labeled 5 cts. each.

Dur selection of varieties, not labeled, 6 for $25 \mathrm{cts}$; 13 for $50 \mathrm{cts}$.

Argyle. Bright carmine pink; large double flowers; perfect calyx

Albertina. Strong healthy habit. Color, bright pink Very fine,

Bon Ton. Bright maroon searlet; large fragrant, deeply fringed fiowers. 10 cts. Bridesmaid. Fine large delicate blush pink. Healthy habit. Very pretty.

Eldorado. Clear yellow, edged and penciled with carmine. Very desirable.8c

Empress. Bright rich crimson; base of petals scarlet. Large, double, deeply Firefy.

Intense tirey scarlet: fine double fowers on long stems. Very fine. Flora Hill. (New.) The largest pure white Carnation to date. Clean and Gealthy and a wonderful bloomer, double and fragrant towers.

Gold Finch. Color. golden-yellow, edged and striped with carmine. Fine.locts Golden Gate. Pure golden-yellow, sometimes slightly striped with carmine.

Genesee. Large, perfectly double, pure white, fragrant flowers. Try it.

Hinze's White. Very popular. Creamy white, fringed, very fragrant flowersHelen Keller. A fine new Carnation. Pure waxy white, delicately edged and Jacqueminot. Dark crimson. resembling in color the popular Jac ueminot Rose. A desirable variety in every respect. $10 \mathrm{cts}$. Jack Frost. New large white Carnation. which is exceptionally fragrant and beautifully fringed. Give it a trial.

Lizzie McGowan. Another grand pure white variety that would flowers are beautifully fringed.

Minnie Cook. A pretty new Carnation. Color, purest white, deliately penciled with carmine: of compact growth

Mayor Pingree. Fine new Carnation. Color. lemon yellow, lightly riped pink, occasionally blotched with white Price, 10 cents.

Peach Blossom. Bright peach blossom pink. Very fine.

Portia. Very popular. Color. blush and firey searlet. Excellent.

Starlight. Creamy white with canary yellow shadings. Fine

Wm. Scott. Probably the best pink Carnation yet introduced. and ore largely grown than any other. A pleasing shade of soft pink.

\section{DAY LILY, OR FUNKIA.}

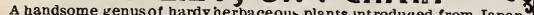
They are foliage and their beautiful frasrant. white. lily.like fowers. manent plant on the lawn or in the garden they have no equal. They are rapid growers, making large clumps in a short time. They thrive best in a partially shaded. moist situation We offer the following Grandiflora. Plain green foliage, beautiful pure white. lily-like
gowers produced in great profusion in June and July Medio Variegata. Beautiful variegated green and white foliage. A very show $y$ and attractive plant. Give it a trial. Priee, 20 eents.

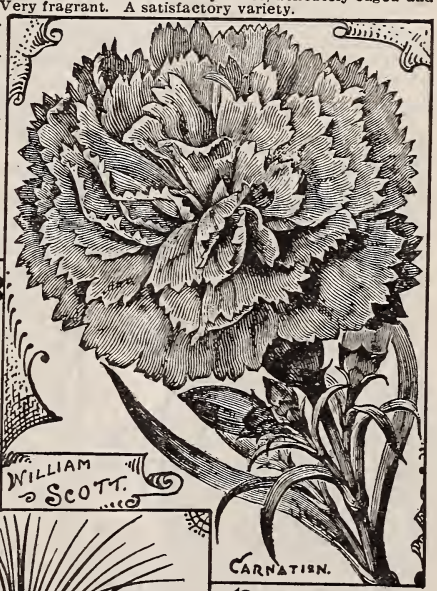

Dracena.

Neut Double White Daisy.

Snowerest, A most distinet variety. and an improvement on all ex- $\curvearrowright$ Sco $\mathrm{C}^{\top}$. in comparison with other varie ties, is gigantic. The flowers are borne on stout. stiff stems from 6 to b inches long, and of the purest white and full to the or sugar loaf form dica cover a silver dollar. It makes an admirable hardy the same treatment as violets. Price, 8 cents.
tonts C Night Blooming Gereus. These are curious plants belonging to the cactus family ; of climbing habit, producing enormously large bell-shaped flowers of rare beauty and great fragrance. No plant will attract more attention. proach of darbreak. Price, 15 cents each. tings not rooted, 5 cents each.

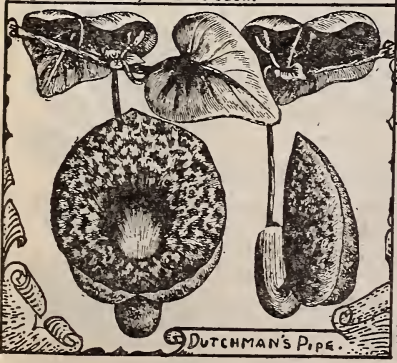

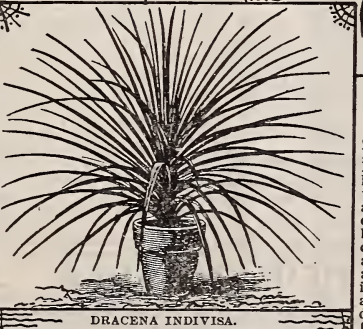

\section{Dutchman's Pipe? Aristolochia)}

A very rapid summer climbing vine, bearing profusely, even on small vines its very odd but handsome. attractive fowers. Nothing in our house attracts more attention than this beautiful vine when in bloom. The flowers are three inches or more in diameter, of a rich dark purple color ornamented throughout with irregular markings of creamy white, and having a yellow throat. Owing to its peculiar shape it is commonls called "Dutchman's

Pipe." Price, only is cents each.

\section{GHOIGE DOUBLE DAHLIRS.}

The Dahlia is one of the showiest of our autumn flowers. Commencin to flower in July they are a perfect blaze of bloom until stripped by frost. inclu are especially fine for cut-1lowers. We offer a number of varietie of each variety. Price stron feld groover. wil not permit a description mail) $15 \mathrm{cts}$. 6 for 50 cents, by 
5. TEMTPLIN \& SONS, GALLA, OMIO F SEEDS, PLANTS \& BVLBS BY MAII

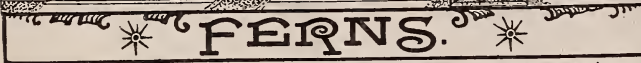

Ferns are fast growing into favor and deservedly so, as nothing beautifies a home mure than a few choice Ferns. We offer only a few of the more easily grown varimoisi, shady situation, but will succeed admirably in the ordinary living room. The plants we offer are extrd strong plants that will give satisfaction.

Nephrolepis Bostonian. (The Fountain Fern.) Certainly one of the most beautiful green fronds often attaining a length of 5 to 6 feet, arching and drooping over in the most graceful manner.

Nephrolepis Exaltata. The famous $\mathrm{S}$ word Fern. Universally admired as grown specimens the fronds attain a length of 6 to 7 feet. arching and drooping over in every direction in a most graceful manner. Th. Nephrolepis Cordata Compacta. One of the finest for house culture. Of compact habit with just sufficient arch to make them graceful. A single plant will

Nephrolepis Davaleoides. A very pretty dwart variety of Sword Fern wit Nephrolepis Davaleoides. A rer prets dwakes fine specimen plants about a foot in height. Vers desirable. Price, 10 to 20 cents.

Pteris Argyrea. (Silver Fern) A very show y strong growing Fern. Fronds likht green with a broad band of silvery white down the centre of each. A

Pteris Alba Lineata. A very pretty and useful Fern, especially for hanging baskets, vases, etc. Narrow green fronds with white band. Price, 10 cents.

Pteris Lineata. Similar to Alba Lineata but a stronger grower and having plain green fronds. Unsurpassed for vases. etc. Price 8 cents.

Pteris Serrulata Cristata. A very attractive Fern 8 to 12 inches
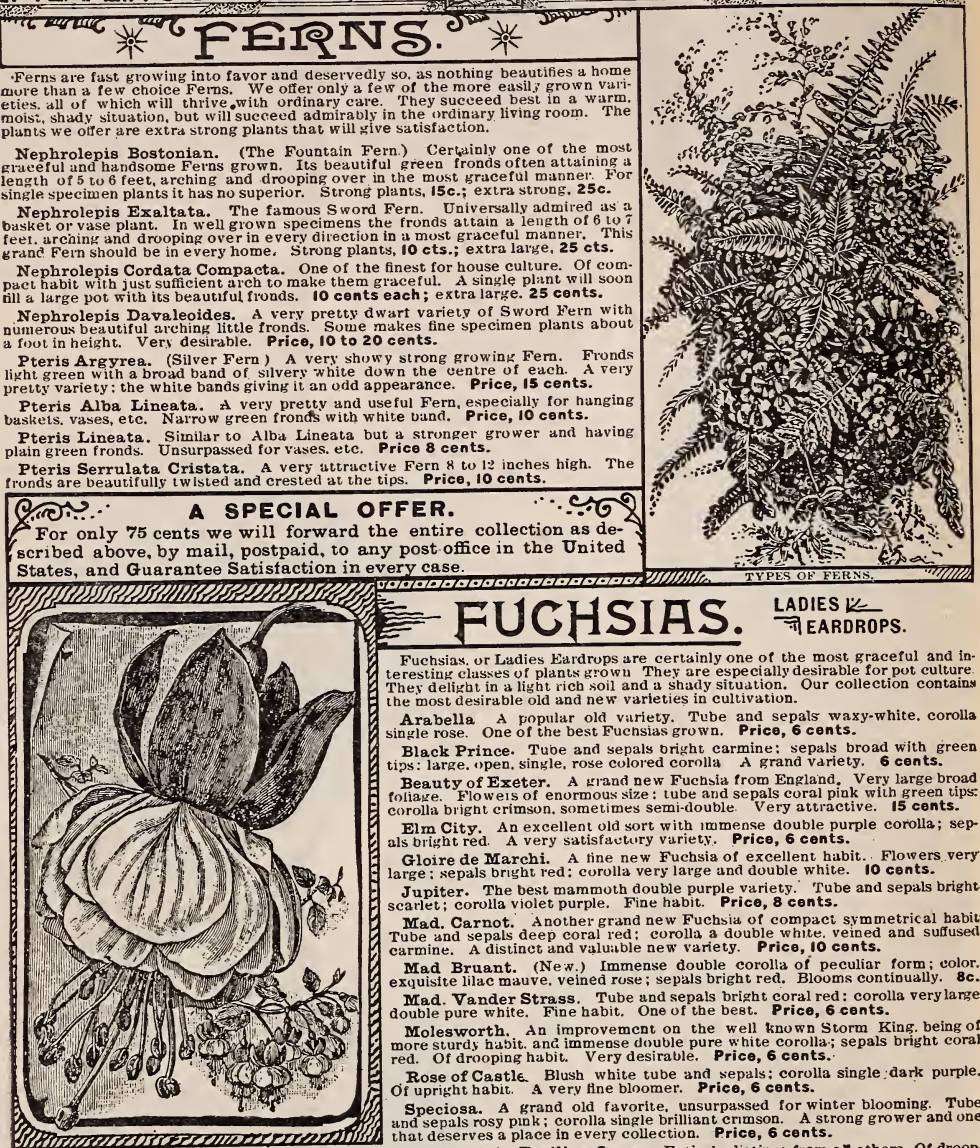

$\because$ Q

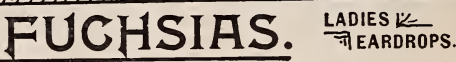

Fuchsias or Ladies Eardrops are certainly one of the most graceful and interesting classes of plants grown They are especially desirable for pot culture. They delight in a light rich soil and a shady situation.

A popular old viriety. Tube and sepals wasy-white, corolla Arabella A popular old vitriety. Tube Price, 6 cents.

Black Prince. Tube and sepals bright carmine; sepals broad with green Black Prince. Tube and sepals bright earmine: sepals broad with

Beauty of Exeter. A grand new Fuchsia from England. Very large broad poliase. Flowels of enormous size : tube and sepals coral pink with green tips: corolla bright crimson. sometimes semi-double Very attractive. 15 cents.

Elm City. An excellent old sort with immense double purple corolla; sepals brisht red. A very satisfactury variety. Prico, 6 conts.

Gloire de Marchi. A tine new Fuchsia of excellent habit. Flowers very rge : sepals brisht red: corolla very large and double white. 10 conts.

Jupiter. The best mammoth double purple variety. 'Tube and sepals bright carlet; corolla violet purple. Fine habit. Price, 8 conts.

Mad. Carnot. A nother grand new Fuchsia of compact symmetrical habit Tube and sepals deep coral red; corolla a double white. veined

Mad Bruant. (New.) Immense double corolla of peculiar form; color exquisite lilac mauve, veined ruse; sepals bright red. Blooms continually. $8 c$. Mad. Vander Strass. Tube and sepals bright coral red: corolla very large double pure white. Fine habit. One of the best. Price, 6 cents.

Molesworth. An improvement on the well known Storm King. being of $y$ habit. anc immove red. Of drooping habit. Very desirable. Price, 6 cents.

Rose of Castle Blush white tube and sepals: corolla single :dark purple. Of upright habit. A very fine bloomer. Price, 6 cents.

Speciosa. A grand old favorite, unsurpassed for winter blooming. Tube Speciosa. A and sepils rosy piak; corolia single brilliant erice, 6 conts.

brilliant coral red: Trailing Queen. Entirely distinet from an others. Of droop corolla single peculiar pale rosy mauve: quite dist

ing trailing habit. Fine for baskets, vases, etc. Finwers sion

Price, our selection of varieties, not named, 6 for 25 cents; 3 for 50 cents, post paid.

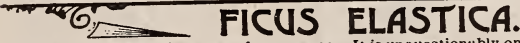

of the most satisfactory de This is the mosphere of the living room, while its deep glossy green color always presents a cheerful aspect. it is particularly adapted to pot culture; may also be planted in the garden or pot sunk in the lawn during summer. The usual price is 51 io 75 cents etich, but having an immense stock we will

FEVERFEW, Little Gem.

This variety is valued very highly. Surpassing the old sort in every way. It is quite dwarf attaining a height of about twelve inches. The tow ers

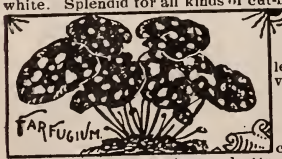

FARFUGIUM GRANDE.

G Leopard Plant: Immense clear bright green leather-like eaves. irregularly blotched and spotted with golden-rellow. A ers useful deeorative pot plant. (See Zebrina.

It distipct and attructlve feature is in the variegation of the foliage, being evenly A strictly perifectly hardy ornamental grass. forming large to sicus. bar wo year.

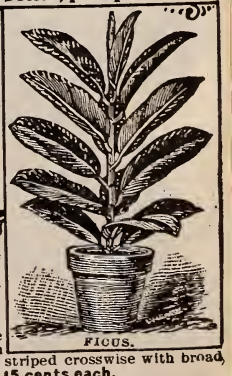




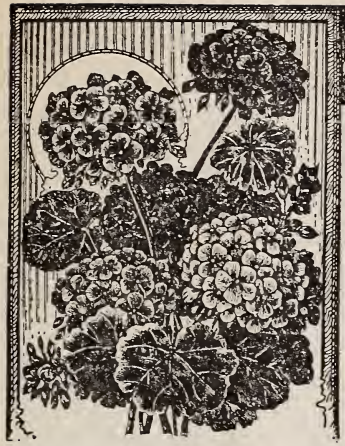

Contraste. Flowers and truss very larre: A very profuse bluomer.

Double New Iife, A great sensation. Outer petals large, color, briltiant scarlet. Each floret containing in the centre a small perfect tower, color pure white: a charming contrast. Must be seen to be appreciated. Price, 15 cents each.

Emile de Girardin. Fine large double pink flowers.

Firebrand. Dazzling scarlet. One of the best bedders. , Golden Dawn. The nearest approach to yellow yet attained. Large double light orange scarlet towers. Fine. 10 cents. A grand variety that should find a place in every collection. grown for bedding than any other variety.

John A. Doyle. A grand new Geranium. Immense larke round trusses of brightest vermilion scarlet; compact habit. 15 cts. J. J. Harrison. Extra large brilliant scarlet. Bruant type.
Francis Perkins. A grand new Geranium. Flower and truss

Grand Chancellor. Dark riolet red, heavily shaded maroon.

Heteranth. Dazzling scarlet; a robust grower. More largely Fine large truss and a strung grower. Very tine. 10 cents.

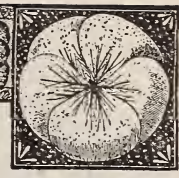

popular bedding or pot plants in cultivation. Every. body grows them because they would not know how to get along without them. crease. Geraniums are one of our speclalties. We sell annually fully one hun gusand Geraniums. We grow about fifty of the best double and single variee are better prepared than ever before to furnish Geraniums in large quanti-

Alpine Beauty. A fine new double pure white rariety. A very free bloomer BEST DOUBLE VARIETIES.

Asa Gray. A valuable old variety of dwarf, compact habit. Color, bright salmon. Beaute Poitevine. Very large semi-double flowers borne in immense clusters; colA very free bloomer either as a pot plant or for bedding. James A. Garfleld. Bright orange scarlet: fine bloomer. La Favorite. Probably one of the best pure white Geraniums. Mrs. Hayes. Beautiful clear pink. A very free bloomer. Marvel. Rich maroon, shaded orange, One of the best. Mad. Jaulin. A very fine new semi-double variety. Very large gorets and truss; centre delicate pink, bordered pure white $10 \mathrm{c}$ Montesquieu. Very large, semi-double, exquisite pale mauve distinct and fine. A very pleasing variety Price, 10 conts.

Rosebud. Pretty imbricated florets like a rose-bud; compact abit. The novelty and merit of this variety are in its perfect russes of niniature rose-bud florets. Color, brisht scarlet, shad puite distinct and attractive. Price, 15 cents.

Robert George. Intense brilliant scarlet. Very tine bloomer. Satisfaction. Brilliant carmine, shaded crimson, Very tine. S. A. Nutt. Rich dark crimson, shaded maroon. Popular. Wm. Pfitzee. Clear orange salmon, distinctly bordered with white; compact habit and a free bloomer. A grand Geranium.
W. P. Simmons. Light salmon scarlet. No. 1 in every way.

VARIETIES

Camille Bernardin. A grand new Carnation. Flower and Mrs. J. M. Garr. One of the finest single pure white becters. truss very large; color, rich rosy peach, with darker veins, streaked and marbled pure white. Price, 10 cents.

Copernic. Perfect large flowers; a beautiful shade of bright rosy Salmon; entirely distinet in color.

Countess de la Pott. Blush white with rosy pink centre.

Electric Iight. Very bright scarlet flowers with white eye.

Favorite. Light salmon scarlet; perfect formed flowers.

Fleur Poitevine. A very distinct new Geranium. Color, brilliant rosy carmine, marbled and striped white; centre shaded orange. A very tine variety. Price, 10 cents.

G. W. Earle. Flowers and truss large, blush white with deep rosy salmon centre. Among the most desirable varieties.

Ia Vestal. Purest white, large, perfect flowers. Does not turn pink when exposed to the sun. A very free bloomer.

Mad. Sampson. Distinct brilliant scarlet; flowers and truss of immense size. One of the best bedding varieties grown.

M. Albert Delaux. Flowers beautiful flesh color, splashed

nd speckled with carmo

Mrs. E. G. Hill. Flowers and truss exceedingly large; color. bright salmon with lighter shadings. A grand Geranlum.

Mrs. Anthony. Pure salunon with white eye. A strong grow er. One of the roost populor bloomers in the entire collection.
Florets nicely shaped and of medium size. One of the freest single pure white bloomers we have

Mad. Bruant. A grand new Geranium that should be in everv collection. Color white, veined with carmine lake, each petal very striking and effective. 10 cts. each.; 3 for 25 cents. Our Pet. An extra tine new Geranium for bedding. Color. compact habit. A free bloomer. Penancy de Nancy. (New.) Single, salmon, distinctiy stripe a with white. A very prof us bloomer, und every flower dis-
tinctly striped. Price, $10 \mathrm{cts}$. Souv. de Miranda. Upper petals sutiny white. bordered rosy carmine ; lower petals bright carmine, splas

Univers. A magniticent new variety. Flowers vers dark ful dazzling velvety shade.

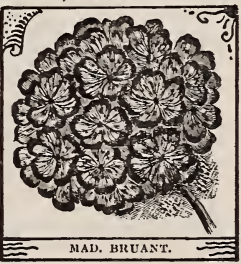

\section{DOUBLE IVY-LEAVED GERANIUMS.}

August Hardy. A magniticent crimson scarlet Ivy Geranium. Flowers very large and perfectly double. Price, 10 cents. Chatrian. A charming shade of rose pink; fine double. $6 \mathrm{c}$. Chas. Turner. Light rosy scarlet, veined with carmine. 6c. Edith Owen. Brilliant rose color; large double flowers, $6 c$. Incomparable. Truss and flowers very large: of fine form. Color, exquisite rosy carmine. A grand variety. Price, $10 \mathrm{cts}$. Joan of Arc. The only purc white double Ivy Geranium. very desira ble variety in every respect. Price, 6 cents.

P. Crozy. New hybrid Ivy; bright scarlet, veined maroon. An

\section{SCENTED GERANIUMS.}

Grown exclusively for the fragrance of their foliage. Indispensable for cut-flower work, button hole bouquets, etc. We offer Balm, Lemon. Nutmeg, Oak Leaf, Pennyroyal, Rose,

Price, 6 cts, each. 5 distinct varieties, our selection, $25 \mathrm{c}$.

\section{FANCY LEAVED GERANIUMS.}

Esteemed for their beutiful variegated foliage, although some of them have very pretty flowers. Unsurpassed for pot culture. Circle of Gold. Green foliage, burdered golden-yellow Fine Crystal Palace Gem. Golden-yellow with green centre. Corienne. Yellow foliage with bronze zone Flowers double, ight salmon pink. One of the best grown.

Happy Thought. Green foliage with golden-yellow centre. Mad. Salleroi. Compact habit: foliage small with white eye. McMahon. Golden-yellow with light chocolate zone. Fine. Mt. of Snow. Foliage green, bordered snow white. Try it. Zulu. Golden-yellow with broad rich chocolate zone. Fine. Price, 6 cents each; 5 for 25 cents, postpaid.

GOLDEN TRICOLOR GERANIUM.

Mrs. Pollock. A grand ornamental plant. Flowers single scarlet. Foliage green with broad yellow margin and rich chocolate zone, margined scarlet. The diferent colors nicely blended to

\section{ग्र




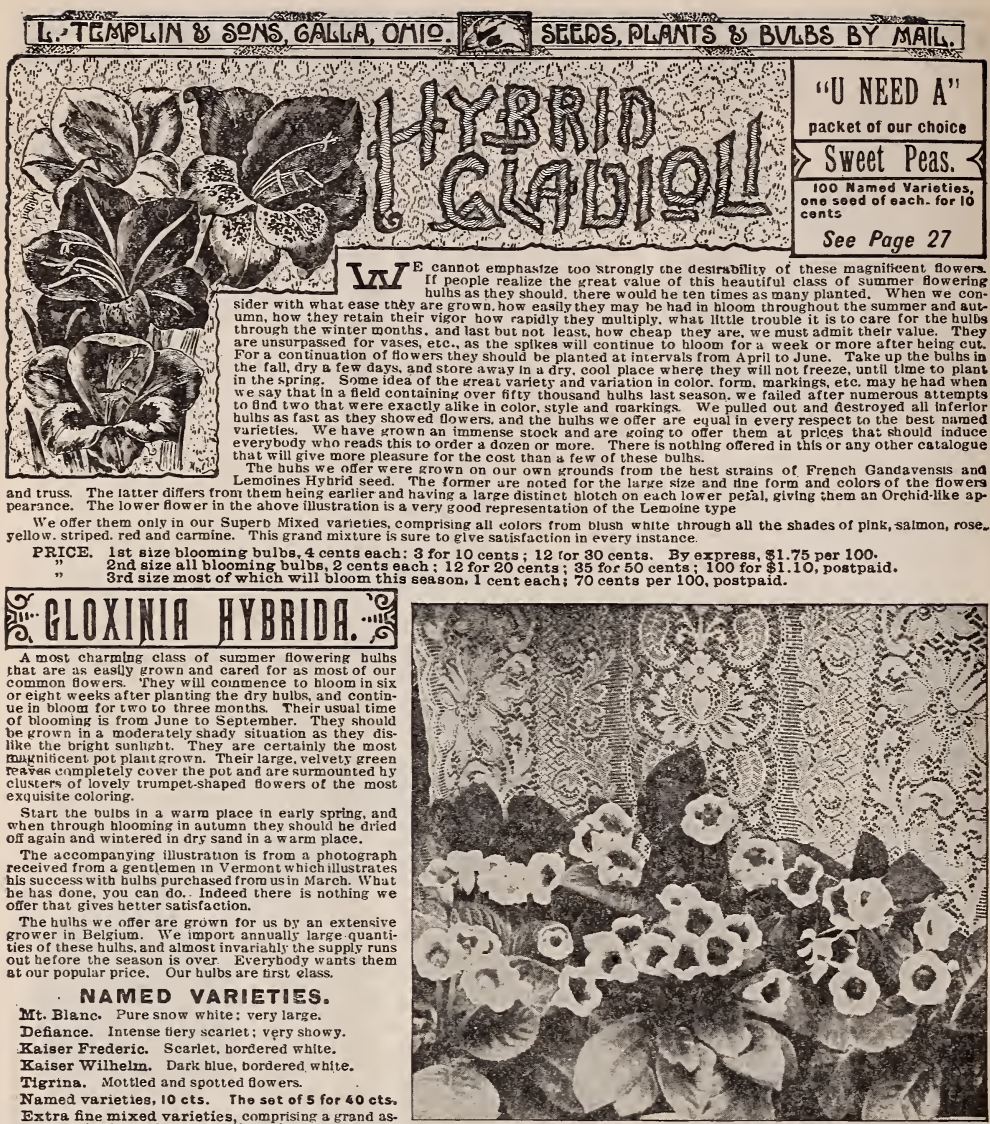

Extra fine mixed varieties, comprising a grand a
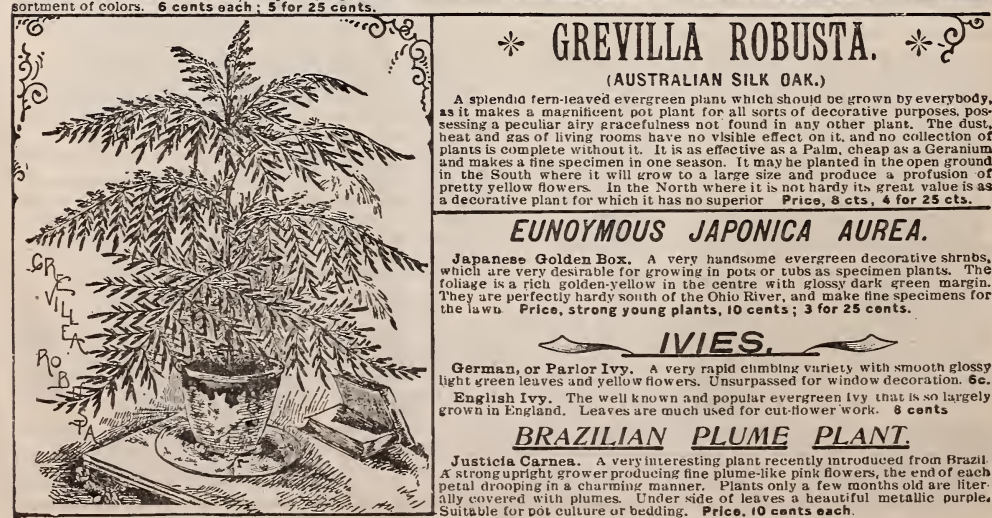

(AUSTRALIAN SILK OAK.)

A splendia fern-leaved evergreen plan whlch should be grown by everybody, sessing a peculiar airy Rracefulness not found in aecorative purposes, posheat and gas of living rooms have no vlsible effect on it, and no collection of plants is complete without it. It is as effective as a Palm, cheap as a Geranium and makes a tine specimen in one season. It may be planted in the open ground
in the South where it will srow to a large size and produce a profusion of pretty yellow flowers. In the North $w$ here it is not hardy its great value is as a decurative plant for which it has no superior Price, 8 cts, 4 for $25 \mathrm{cts}$.

\section{EUNOYMOUS JAPONICA AUREA.}

Japaness Golden Box. A very handsume evergreen decorative shrnbs, which are very desirable for growing in pots or tubs as specimen plants. The foliage is a rich golden-yellow in the centre with glossy dark green margin. They are perfectiy hardy solith of the Ohio River, and make tine spe.
the law wrice, strong young plants, 10 cents; 3 for 25 conts.

German, or Parlor Ivy. A very rapid climblng variety with smooth glossy German, or Parlor Ivy. A very rapid climblng variety with smooth glossy
light sreen leuves and yellow flowers. Unsurpassed for window decoration. $6 c$. English Ivy. The well known and popular evergreen Ivy that is so largely BRAZILIAN PLUME PLANT.

Justicla Carnea. A very imteresting plant recently introduced from Brazil petal drooping in a charming manner. Plants only a few months old are liternlly covered with plumes. Under side of leaves a heautiful metallic purple. 
TL. TEMPLIN \& SONS, GALLA, ONIO. CAED, PLANIS \& BULBS BY MAIL.

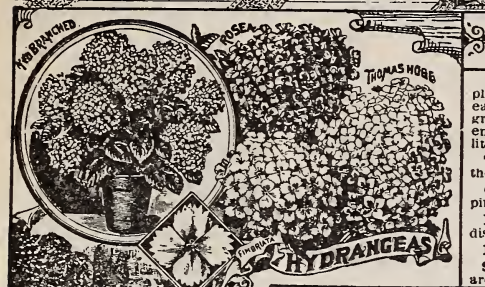

HYDRANGEAS.

W'e know of no plant tnat is more use ful as a decorative pot or tub
lant for the porch or varanda tnan the Hydrangea. They are or the easlest culture, increasing in stze and beauty trom year to year or we grown specimen is a beautiful sight, remaining in bloom throughout the th season. They snould be wintered dormant in a cold cellar A the best sorts Thomas Hogg. Immense trusses of pure white
he most profuse bloomers we offer Price, 6 cents.

Otaska. A splendid vartety trom Japan. Immense trusses of bright ink flowers tinted with blue a very satisfactory variety 8 cents New Red Branched. Distinct trom all others Stems deep red sh purple, large trusses of oright rose colored flowers. Pric Hortensia. The well known popular old variety none better $6 \mathrm{cts}$. Stellata Fimbriata. A beautiful pure white variety The petal

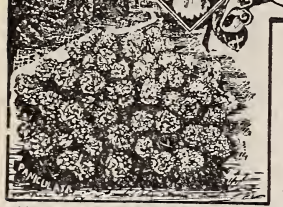

MARDY HYDRANGEA, Paniculata. ऊ0ग op a sinfle plint. Strong dormant roots, 6 to 16 cents each.

\section{бुC CHINESE HIBISCUS. J⿹}

in great growing tropical shrubs with glossy green foliage. produenno enormous Hower in great profosent May be grown in tuns and kept for year.

Auriantica. Large double orange salmon flowers. Very novel and showy $8 \mathrm{cts}$

Cooperii Tricolor. Follage beautifulls vartegaced with green, white, and pink Howers

crimson. A magniticent foliage plant. Price, 10 cents oach.

Grandiflora. Rich glossy green foliage and immense single crimson scarlet flowers $6 \mathrm{c}$.

Miniatus. Semi-double, brigbt vermilion searlet dowers. petals waved and recurved

A very handsome and desirable variety Price,

Vorea Sinensis. Very large single brilliant red towers, 5 inches or more acruss 6 cts. Versicolor. Combining many colors, being handsouely striped and shaded crimson, rose ant white. Of the easiest culture. Price, 8 cents each.

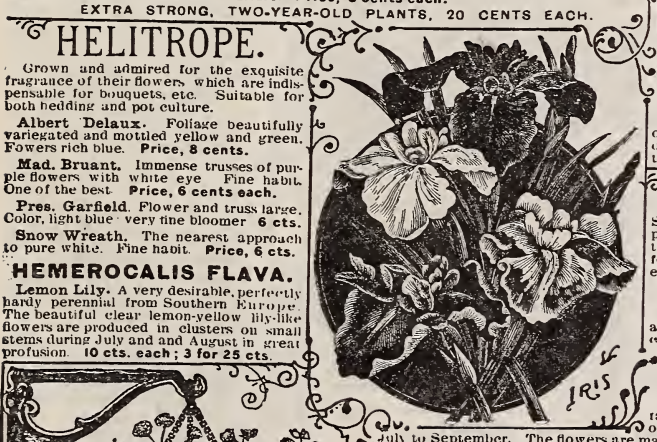

$9 \cos ^{2}$

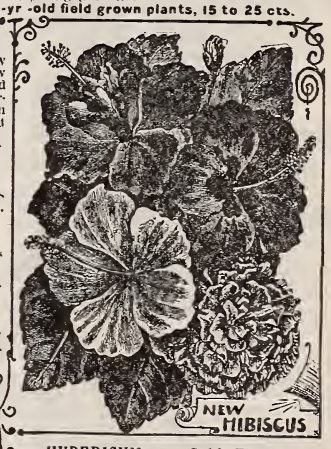

HYPERICUM, or Gold Flower.

A very pretty perfectly bards little shiut
of graceful habit. Producing a a abuneance of clear golden-vellow single flowers fully HELIANTHUS MULTIFLORUS. Rardy Yellow Dahlia, or ‥Perennial perennial literally covering itself throughour the late summer and autumn with large. per. ers Hardy eyerywhere 8 cts., 4 for $25 \mathrm{c}$.

IMPATENS SULTANA.

Sultans Balsam. One of our most brill ant and showy pot plants Should be in every o Price. 10 cents each
原象
5 a ing $t$ to 8 inches in diameter and rivaling the Orehid in their rieb coloring and mark. inws. Perfectly hardy every where. A w ell established plant producing a score or more of their beautiful towers. Our stock was imported direct from Japan, and is unsurpassed in quaíty. We offer a half dozen or more separate colors, including LANTANA, or Shrubby Verbena. Jy

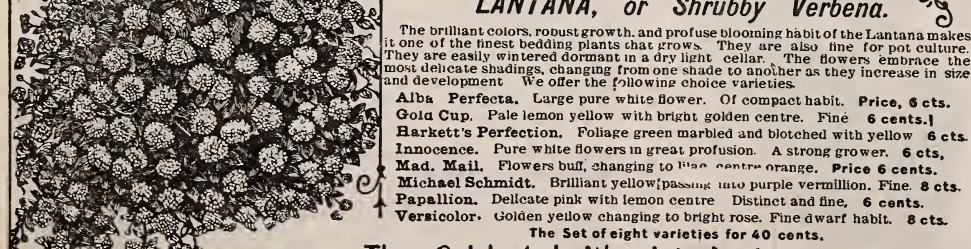 The brillant colors, robust growth. and profuse blooning ha bit of the Lantana makes hey are easily wintered dormant in a dry light cellar. The fowers pot cuiture. size Alba Perfects, Large pure white flower Of compact habit. Price, 6 cts. Barkett's Perfection. Foliage green marbled centre. Fine 6 cents. I Innocence. Pure white flowers in great profusion. A strong grower. $6 \mathrm{cts}$, Mad. Mail. Flowers buf, shanging to litan cantre nrange. Price 6 cents. Papallion. Dellcate pink with lemon centre Distinct and fine, 6 conts. The Gelebrated Weeping Lantana.

9. 2 . Lnquestioably one of the most sutisfactory plants grown for baskets, vases, etc. Of graceful drooping habit introduced this beautiful plant three years a:o and have sold more than a bundred thousand plants. Price. Only 5 cts.; 6 for 25 cts. 


\section{TLMIPLIN \& SONS, GALLA, OHIO, SC SEEDS, PLANTS \& BVLBS BY MAIL.}

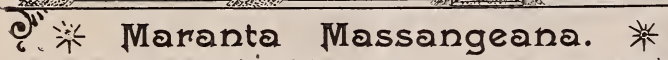

A most beautiful ornamental plant, suitable tor yrowing ho pot for table aecoration, etc.. also valuable for wardian cases, ferneries, etc. It has broud bright sreen foliage beautífully striped with dark plants in our greenhouse. Price, nice young plants at is cents each

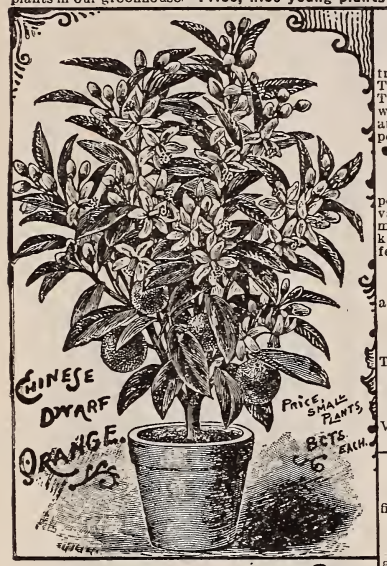

Jasmines.
CHINESE DWARF ORANGE.

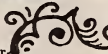

Margurites. A popular class of plants of the easiest culture, producing in the A distinct and pretty upright ereet growing variety natving metallic green follage,
ano very pretty bright yellow llowers. Contunually in bloom. Fine for pot culture. 8 c.

$\Rightarrow$ PASSION VINES. Niñ One of our most rapid climbing viues. Admirably adapted for bay windows, ete Ars

Constance Elliott. Pure white. A the new variety. Price, 6 cents. Very larre showy tlowers. A strong robust grower. Price, 10 cents each. Smithii. Pretty bngat carmine pink tlowers in great profusion. Valuable. 6 ots.

what pan the PARIS DAISIES.

r work. Two varieties, Pure White and Golden-yellow. 5 cents each.

Certainly one of the most valuable

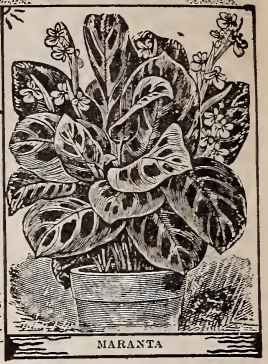

OXALIS ORTGIESII.

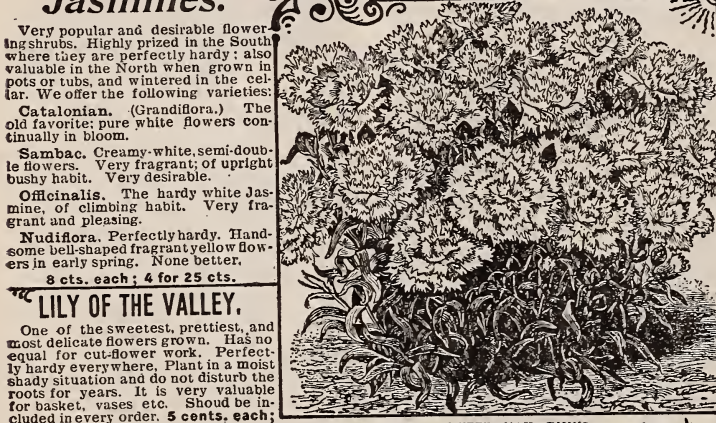
basket plants we have yet seen. It is
a rapid grower: its long. very beautis ful plume-like fronds drooping in the
most graceful manner. Keep well watered as it delights in plenty :or
moisture. Price, 6 cents each. CHINESE PRIMROSE, Primula Sinensis. One of the most satisfactory plants grown for winter blooming, producing its large of easy: if potted and kept in cool shady place
will make nice larre blooming plants will make nice large blooming plants
for next winter, We offer white, pink, 6 cents each: 5 for 25 cents.

OLEANDERS.

A popular old fa vorte. unrivaled as a tub or pot plant for the porch or They delight in ricts soil and plenty of Water. We oller $t$ wo best sorts. pink variety 10 cents each.

Dbl. White. immense clurters of cluded in evers order. 5 cents, each, 50 cents per dozen.

\section{Hardy Sweet May Pinks.}

These are among our most desirable garden plants. They are entirely hardy and of dwar compast growth, making them very desirable for edges ind borders, cemetery planting, etc Gweet. Their exquisite fragrance should secure for them a place in every gardet. With one or 6weet. Fheir exquisite fom but once a year in May or June

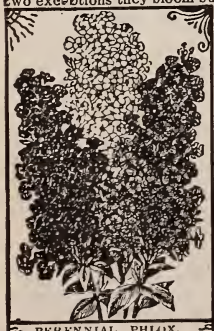

Abbottsford Deep carmine, marbled white.

Attraction. Heavily laced white on maroon ground. Anna Boline. White iriuged, base of petals maroon. Fine, Essex Witch. Bright rosy pink, fragrant, heavily fringed. Gertrude. Rosy carmine, veined and laced with white. Juliette. Cherry red, yariegated and laced with white. Snow Pure white, very double, fringed, and fragrant. Snd Fus Price, 5 cents each; 6 for 25 cents. "न्E Everynody should grow a few clumps of this most useful har parieties. We know of no other more show plants for the law Amphion. Rich purple crimson, very dark.
Amparden. They need no protection whateve

Athis. Light salaion rose. Very fine large trusses

The Pearl. Pure white A grand variety in every respect.

Washington. White with distinct rose eye.

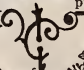




\section{H CHINESE FAN PALM.}

Latania Barbonica. This is the typical Palm and is more largely grown than all other varieties combined (excepting the Kentias.) Its strong healthy habit, large glossy green fan-like leavell gromn specimen of Latania. We grow them by the thousands. We wish to state that young Palms usually do not resemble the

lustrations. The characteristic leaves $10 \mathrm{cts}$. Two-year-old plants, showing Price, strong one-year-old plants, $10 \mathrm{cts}$. Two-year-old plants, showing checimens, by express, with 3 to 6 characteristic leaves, 75 cts. to $\$ 2.00$,

$$
\text { 2KENTIAS. }
$$

Anotber grand Palm that is becoming very popular. It differs from the Latania In being of a more upright, graceful habit. There are two varieties-Balmoreana and Fosteriana, differing slightly in habit of growth. Their graceful arching foliage render them unsúrpassed for table decoration. Nice young plants 15 to $25 \mathrm{cts}$.

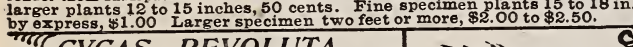
"TCYCAS REVOLUTA.

Japanese Fern Palm. A noble and majestic plant, and probably the most valuablo decorative plant grown. Their heavy glossy dark guco, fronds plants are so frequently exposed. We ofier a rew diameter and 12 to 18 fronds. No small plants to of fer. Price, $\$ 3.00$ to $\$ 5.00$, according to size.

\section{Pineapple. "भु⿰冫्⿱一⿻上丨巨大} It tisis not generally known that the Pineapple is

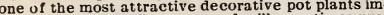

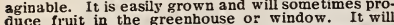
thrive in ordinary loose sandy soil with plenty of meat, though it $w$ ill stand a variety of temperatures. This is the Pineapple of commerce, Somewh
sembles Pandanus. Try it. Price, 20 cents.

\section{DOUBLE PETUNIFS.}

The double Petunia is one of the tinest bedding plants for massing mixed borders or vases. The ruffled and perfectly double. We offer pure white. pink blotched and purple blotehed varieties. One Q Silver Striped Peperomia. pretty dwarf growing plant with thick waxy leaves that are beauti white and green. Fine for pots. vases, ferneries, etc. They require

\section{MEXICAN PRIMROSE.}

A charming basket or pot plant not exceeding ten inches in height, but inelines to a trailing habit. Col veined with scarlet and has a whit centre. A very fine plant for win-
dow decoration. Price, 8 cents.

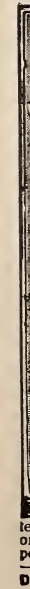

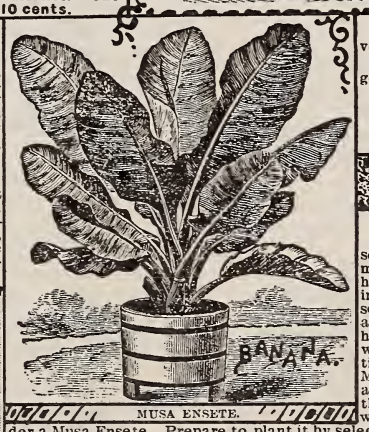
6 Crocosmiflora. Deep golden orange. A Gerbe de Or. (Golden Sheaf.) Splendid golden-yellow. One of the best.

Rosea. Brlght rose. Very distinct.

Price, any variety, 5 cts.; 3 for 10 cts. 3 each of the four varieties, 25 cts. MUSA ENSETE.-. (Abysinian Banana.)
We know of no other plant that produces o striking an effect as a well grown specimigh with massive leaves eight feet or more in length by thirty inches broad. and you have able rapid growth: a small plant attaining the height of 10 to 12 feet in a single season. A tion than anyother plant we have evergrown Mrs. J. C. Kirk, of Canfield, Ohio, says: "It ttracts more attention than any other plant hat was ever grown in the town. If you ting a sheltered location where the strong $\leftarrow$ MONTBRETIAS.

The Montbretias are one of the brightest and bes: of Summer-dowering bulbs, and it bas why they are not more generwhy they are not more generonce tried they will become favplanted from April to June in olumps or busbes of three to a fectly hardy, and once planted

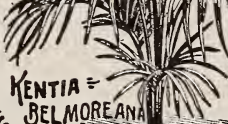

9 can bo left to care for them.

selves. In growth they resem.
ble the Gladioli, and produce

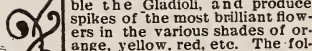
(2) ange, yellow, red, etc. The fol varieties, and are offered at a er a Musa Ense te. Prepare to plant it by selecting a sheltered location where the strong or 4 feet in diameter and the same in depth and fill it with good rieh soil, well rotted manure, Plant last of May or 1st. of June and water frequently, especially in dry weather,
strong young plants, $15 \mathrm{c}$., by mail. Large plants in May, $50 c$. to \$1.00, by Ex. * PANDANUS UTILIS, * * Screw Pine. So ealled owing to the spiral arrangement of its foliage. Certainly one of our most desirable decorative plants of very easy
culture. Withstanding to a marked degree the hot. dry atmosphere of our living rooms. Its dark glossy green gracefully arched, serrated foliag plant. Also valuable for centre of vases, etc. Strong plants 6 in. high, $10 \mathrm{c}$. : extra stron "GPRYNIUM VARIEGATUM. An elegant foliage plant somewhat resembl ng the Canna in habit or growth. The leave being borne on erect stems a lout or more high are 6 to 9 inches long. They are a bright pale green irregularly variegated white. In sonie eaves the whole area is white, while in others only halr, and again in others there are only a few Irregular stripes. It is of easy culture either as a bedding plant or grown in
pots. It may be wintered like the Gladioli. Strong tubers, $15 \mathrm{c} . ; 2$ for $25 \mathrm{c}$; 5 for $50 \mathrm{c}$ DON'T THINK BECAUSE OUR GOODS ARE CHEAP THAT THEY ARE INFERIOR.

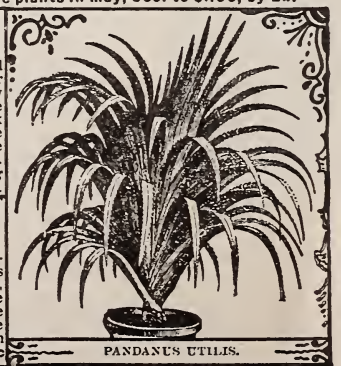

WE GUARANTEE THEM FIRST CLASS 

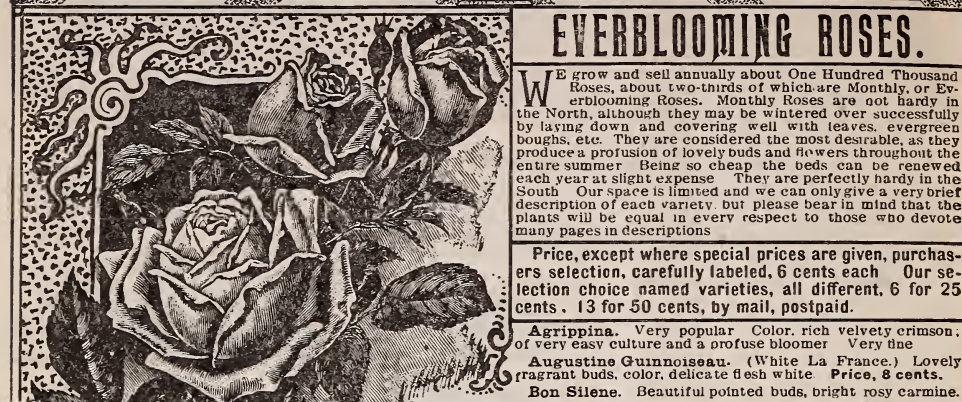

Price, except where special prices are given, purchasers selection, carefully labeled, 6 cents each 0ur selection choice named varieties, all different, 6 for 25 cents . 13 for 50 cents, by mail, postpaid.

Agrippina. Very popular Color. rich velvety crimson; Augustine Gunnoiseau. (White La France.) Lovels ragrant buds, color, delicate $f$ esh white Price, 8 cents.

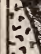

If Bride. Very popular Lovely large white ouds. Fine. 8 cents.

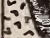

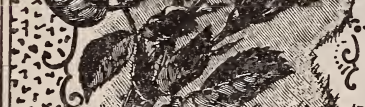

if Bridesmaid. Large, perfectly formed. delicate pink buds. 8 cents.

th Caroline Marniesse. Hards everblooming, pretty perfectly double, 1. 5 coquet de Lyon. Remarkably free bloomer, bright canary yellow Countess Anna Thunn. Pretty citron ycllow with coppery centre. Cornelia Cook. Extra tine, large, pure white, pointed buds. 8 cents.

Countess Bretuel. Delicate apricot with orange centre. Very fine. $10 \mathrm{cts}$. Duchess de Brabant. Bright rose, shaded amber and salmon. None surpass it in fragrance or vigor. One of the most satisfactory Roses grown.

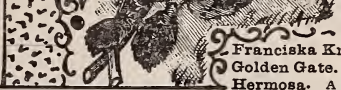

A popular old Rose.

Henry Meynandier. Large, bright rose color, delicately shaded: very fragrant. Of strong, vigorous habit.

La Pactolo. Color, pale sulphur jellow, pretts pointed buds. A remarkably free bloomer and of easy culture. Iouisa de la Rieve. Delicate blush, shaded salmon: pretty
pointed buds, A tine grower and a free bloomer.

La France, (Hybrid Tea.) One of the most popular Roses grown. Perfectly formed buds and flowers: color, peach blosMadam Camille. Fine extra large, perfectly double, delicate salmon pink. A very pleasing Rose. Maria Van Houtte. Pretty buff, delicately shaded rose.
Healthy and vigorous. One of the best Roses in cultivation.

Maman Cochet. Unquestionably one of the tinest Roses ever introduced. Beautiful large buds and double towers; color,

Mary Washington. Very popular, pure white, everbloom. Fo wers produced in large clusters.

Maria Guillot. It is useless to look for a better pure white
Rose. Extra large, full, double, perfect fow ers.

Marion Dingee. Brilliant purplish crimson. Very distinet and fine. Highly recommended for bedding.

Madam Welch. Large and full. Color, apricot with orange shadings. An extra tine Rose. Price, 8 cents each.

Malmaison. A noble Rose, fowers extremely large and double. Color, clear flesh pink. Fine for beddink. $10 \mathrm{cts}$

Marshall Roberts. Pure white, faintly tinted with blush snd lemon yellow. Flowers large and fragrant.

Meteor. Rich dark velvety crimson: very double and perfect
(New.) Creamy white, slightly tinted bulf at centre. Flne. 8c. salmon with coppery shadings. One of the best.

, color. creamy white, beautifully tinted. A strong grow
Color, brlght rosy pink. A constant and profuse bloomer. Mons Furtado. Clear sulphur yellow, pretty pointed buds and large well forned double flowers. Very fine bloomer Mad. Martha du Bourge. Blush white, edged and shaded rosy carmine. Nicely cupped petals. Fine. Price, 8 cents. Marquis Vivian. Color, rich violet crimson, centre and base of petals canary yellow Very tine Price, 8 cents.

Princess Sagan. Very tine Tea Rose. color, intense crimson carlet. Of very free blooming habit; fine for bedding.

Pauline Ia Boute. Salmon rose, unted fawn and amber: pretty delicate pointed buds. Sure to give satisfaction.

Papa Gontier, Vigorous grower and profuse bloomer; large buds; color, brilliant carmine rose Price, 8 cents.

Pernot's Triumph. (Hybrid Tea.) A very tine Rose. Colr, bright red, changing to crimson. Fragrant buds

Perle des Jardins, Very large, double, golden yellow flowers. Resembles the M. Neil in size and color. None better. 10c. crimson. The flowers are produced on stiff. erect stems. 10c. Safrano. Beautiful buds; color. apricot, shaded fawn and orange. Highly prized on account of its pretty buds

Sanguinea. Flowers intense glowing crimson, produced in the greatest profusion. Fine for bedding.

Snowflake. (White Hermosa) A remarkably free bloom. ing pure white Rose. Satisfactory in every respect.

Souv. de Gaulaino. Rich velvety crimson, very dark and handsome. Flowers large and perfectly double: of easy culture Solfaterre. (Cloth of Gold.) This grand Rose is of rapid Solfaterre. (Cloth of Gold.) This grand Rose is of rapid climbing habit. Flowers very large and double. color, rich
den-yellow A very desirable variety Price, io cents.

\section{* JAPANESE POLYANTHA ROSES, 洸}

No class of Roses will produce so many fowers throughout the season, and give as general good satisfaction as the Polvantha. They are almost perfectly hardy, requiring only slight protection during winter, and will produce
three times as many flowers as any other class of Roses. They are of dwart, compact habit and of the easiest culture. The fowers are produced in clus. compact habit and of the easiest culture. The flo $\pi$
ters. They are unsurpassed for cemetery planting.

Clothilde Soupert. A grand Rose in every respect, perfectly double flow ers: color, pearly white, shaded to pink centre. Price, 6 cents.

Iroselle. (Yellow Soupert.) Were we to grow mily one Rose it would certainly be Moselle. Perfect forvers and buds: color, creamy w
centre shaded orange. Could not be improved on. Price, 8 cents.

Etoile de Mai. A charming new Polyantha Rose. Color, rich creamy Etoile de Mai. A charming new Polyantha Rose. Color, rich ere
white, changing to pure white. Very profuse bloomer. Price, 6 cents. George Pernet. Bright peach blossom pink with silvery shadings. fuse bloomer. literally covering itself with lowers Price, 6 cents.

Mignonette. Flowers bright pink, borne in immense clusters. 6 cents.

Perle de Orr. Creamy w bite with orango shadings. Pretty pointed ut ti Perle de Orr. Creamy w bite with orange shadings. Pretty
buds. Very tine and sure to give satisfaction. Price, 8 cents.

Flora. Flowers medium size, very double and produced in immense clus. ters: color, bne ivory white, faintly tinged with blush. Fragrant. $6 \mathrm{cts}$.

Mad, Cecile Brunner. Delicate pink, changing to blush white, very del

feately formed bubs, quite double and vigorous. Fine for cutting $6 \mathbf{c t s}$.

Five choice varieties, our selection, for only 25 cents, postpaid.

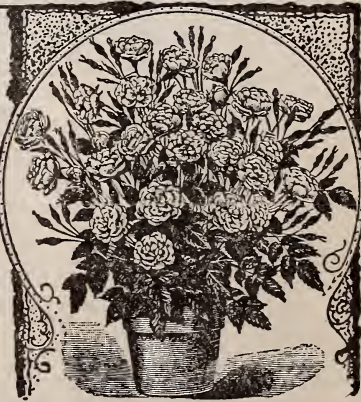

TWO-YEAR-0LD ROSES, We cansupply strong, two-year-old plants of the above varieties of Monthly Roses, also of Hargive good satisfaction. Price, by mail, postpaid, 25 cents each; 5 for $\$ 1.00$. By express, 7 for $\$ 1.00$. 


\section{A Page of Hardy Roses.}

\section{GRIMSON RAMBLER.}

This is notw without aoubt one of the mosi poplar and valuavie koses grown. Is a most vigorous elimber. pertectiy haray and completely covers itself with iw ents plant in every dooryard. Strong plants, $15 \mathrm{cts}$.; 2 for 25 cts. Extra $2 \cdot y$. . 010 , $30 \mathrm{cts}$ Yellow Rarabler. (Oglaia.) This was the sensation of the year last season and if it counes any where near fultilling the deseription it will certaniy be a va ers We have not jet tested its merits Price, strong plants 10 cents. White Rambler. (Thalia.) Style of growth and habit same as the Yello Oler. Flowers double pure white, borne in clusters Frics, Pink Rambler. (Euphrosyne,) Another valuable companion to the obov Buds pretty, light carmine, opening out bright pink, in large clusters. Prico, $10 \mathrm{cts} 0 \mathrm{ach}$

\section{Hardy Perpetual Roses. "कु}

This elass of Roses is admirably adapted for garden culture, or for forming permanent beds where brilliant colors, Vurying from pure white to glowing crimson.

Anna de Disbach. Clear brilliant rose Flowers very large and ot tine cupped form.

Ball of Snow. Pure white, doubie and fragrant. Of half elimbing havit. Vers desirable.

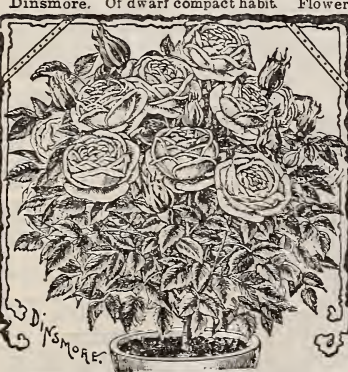

\section{6r.}
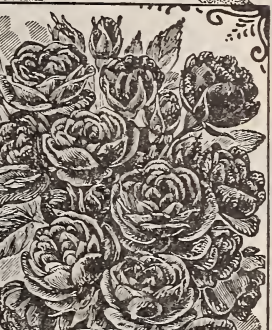
very large, perfectly double, color deep glowing crimson
Blooms continually through the season. is cts.; $2-y$ r.-old $30 \mathrm{cts}$
Gen. Jacqueminot. The most popular Rose grown. Color rich
velvety erimson No collection is complete without a "Gen. Jacq."
Glorie Lyonaise. The nearest approach to a yellow Hybrid Per.
petual Rose yet atrained. Color pale salmon yellow, quite distinct.
Glorie de Margotten. Flowers large globular in form, very fra.
grant, color clear dazzling red. Price, 15 cents each. Glorie de Margotten. Flowers large globular in form, very fraJohn color clear dazzling red. Price, 15 cents each.

John Hopper. Brignt rose with earmine centre, large and full. Lady Emily Peele. Medium size full double flowers. color pearly Me solimes shaded delicate rose. A very vigor.

rta. Extra large bright clear pink flushed crimson. Shomy Mad. Gabriel Luizet. One of the most beautiful Roses. Very full and double; color Mad. Joser iragrant Mad. Joseph Desbois. Flowers of large size and fine form, full and double; color a pleasing blush white. A strong and rigorous grower.

Marchioness of Lorne. Fine cupped flowers, color deep rose, centre vivid carmine. Paul Neyror. Fluwers of immense size, color clear bright shining pink, Very double. Pæony. Large perfectly aouble, color, rich erimson, shaded maroon.

Summer Queen. An excellent garden Rose. Flower large double clea: pink.

Ulrich Bruner Extra large bold flowers of rich glowing crimson tamed with scarlet;

75 dished's Caprice. (Stripea Perpetual Rose.) Grand; color soft sating pink, distinctij Price. except where noted, 8 cts.; 7 for 50 cts, $2-y$ t. 0 id

\section{* EVERGREEN HYBRID MEMORIAL ROSES. **a}

A new elass of nardy Roses that is attracting much attention. They are nybrids of the beautlful Jap. anese ereeping Wichiariana kuse. They are of wonderfully rapld growth and

Manda's Triumph. Large clusters of doubi6, pure white, fragrant flowers. Price, 10 cents.

Pink Roamer. Close heads or clusters of bright pink, single. fragrant llowers. Rapid grower. 80.

Universal Fevorite. Very rapid elimber, double rose colorea flowers in clusters. 10 cents.

South Orauge Ferfection. A rapid creeping varlety. pretly double, soft blush pink flowers. $10 \mathrm{cts}$. Rosa Wichiariana. The true Memorial kose from Japan. Glossy evergreen foliage: creeps elose co the ground, Unsurpassed for cemetery plenting. Flowers single white in gredt profusion. $10 \mathrm{cts}$.

\section{Hardy Climbing Roses.}

Baltimore Beli6. Pale blush changing to pure wbite. Double flowers in clusters. A cholce Rose. $6 \mathrm{c}$. Empress of China A new climbing Rose claimed to be hardy Introduced from China. Flowers soft red changins to pink Blooms continually, and is a very rapid climber. Price, 10 cents oach.

Prairie Queen. Bright rosy pink, large double tlowers. One of the best. Price, 8 cents.

Russell's Cottage. Dark velvety erimson. Very double Price. 10 cents.

Seven Sisters. Flowers in clusters, color ranging from almost white to crizason. 8 cents.

"No

The Moss Roses are perfectly hardy every where. They are strong and vigorous growers, and much
Idmired for their bright healthy foliage and mossy-like covering of the buds Countess of Murinais. Large, pure white, alouble flow.

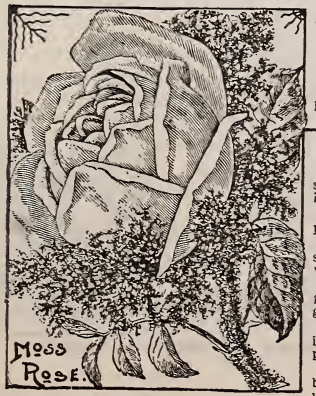
John Cranston. Very doubie, deep crimson.

Luxembourg Bright erimson, large and linely mossed. Princess Adelaide. Bright rose, doubie and tragrana. Whits Bath. Pure snow waite, large ciouble lowers. Price, 10 conts each; tne $\$$ for $\$ 5$ cents.

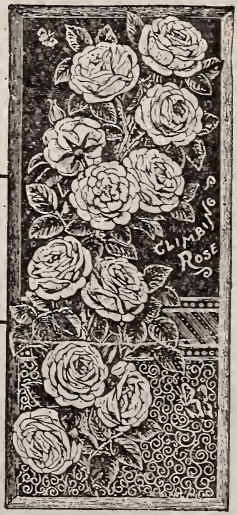
Other Species of Roses. गु Lady Banks, or Banksian Rose. A grand elimbing Rose for the Suthern and Pacifo stales where the winters are mild. Flowers small, very double; creamy white produced in

Microphilla Rose. Small glossy green foliage. Flowers semi-doublo, very pretty long price 8 cunts each.

Cherokee Rose. A reautiful shrub, having deep glossy green leaves and no thorns. Large
single, pure white flowers in yreat profusion single, pure white fowers in preat profusion. Much.esteemed in many parts of the Soutb Anemone Rose. An entirely distinct new elimbing Rose introduced from Europe. Per Pen foliage, and beautiful, large single, white fowers golden-yellow dise and stamens. Very desirable. Price, 10 cents each.

Carmine Pillar. A splendid new Rose. Large single, bright rosy carmine flowers 4 to 5 inches across. Of rapid climbing habit. Foliage of immense size and very tine. Said to be perfectly hardy. Very showy. Prico, 15 cents each.

Christmas Rose. (Helleborous Niger.) This is really not a Rose at all, but produces ure, blooming very freely. Try this new and odd species of Rose. 


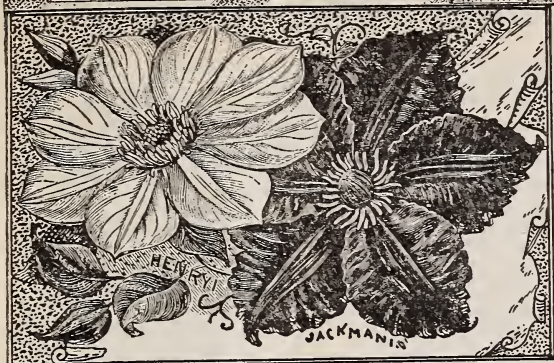
LARGE FLOWERING CLEMATIS?'C

Price, strong two-year-old field grown plants, 35 cents each; 3 for $\$ 1.00$. The set of above 6 varieties for $\$ 1.75$

\section{Clematis Paniculata.}

(Japanese Clematis.) Unquestionably one of the most valuable climb ing vines ever introduced. A remarkably rapid climber. Will cover the enwhite, fragrant flowers. Price, 15 cents each; 2 for 25 cents.

$\cdots$ Clematis Flamula. 今゙

A pretty hardy native Clematís, producing clusters of small pure white, eragrant flowers, which are followed by feathery tufts in the autumn.

\section{G(O, RHODODENDRONS. "We (ROSEBAY.)}

Rhododendrons where known are acknowledged to be the most magni ficent show $y$ and hardy evergreen shrubs that grow. They will thrive in iny good soil and location, although they grow more luxuriantly in well prepared soil. containing a good proportion of leat mold and muck or peat and in partial shade. Their broad, glossy green. evergreen foliage are almost hidaen by mazniticent clusters of flowers in June eight to twelve inches in diam eter. The p are simply grand beyond description. A protec

We offer a choice collection of named varieties comprising pure white cose, pink. purple, etc. in strong bushy plants 18 inches or more in height, \$2.50. By express only as they are too large to mail.

\section{EFrrdy Floxierind Shrlblery.}

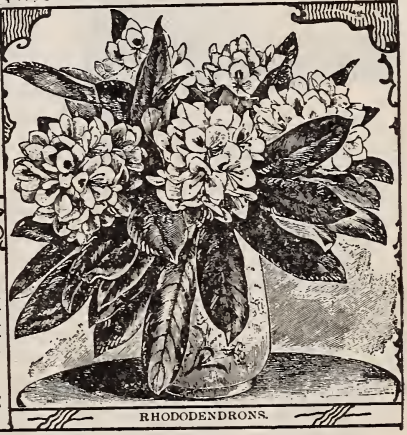

(When once planted they will increuse in size and No garden should be without a good selection of the offer only a féw of the must desirable varieties mostly 1-yr.-old plants.
beauty from year to year, requiring but little care. We oflar Altheas. (Rose of Sharon.) Very showy hardy shrubs with
Honeysuckles. Popular climbers for verandas,
We offer three distinct varieties. Price, 8 cents.

targe double flowers, resembling a double Hollyhock. We otser Whe cents. Colycanthus. (Sweet Scented Shrub.) The popular old ly and profuse bloumers. One of the best. Price, $10 \mathrm{cts}$.

(1) delight fully fragrant shrub, with velvety purple double flowers.
Too well known to need description. Price, 10 cents. Deutzia Gracilis. A fine dwarf growing hardy shrub, with $\begin{aligned} & \text { Spirea Van Houte. A beautiful variet, with pure white } \\ & \text { clusters of pure white single flowers. Price, } 8 \text { cents. }\end{aligned}$ flowers, produced in clusters. Very fine. Price, 8 cents.

Deutzia Crenata fl pl. Pretty double :vhite flowers in clusters, occasionally tinged with pink. Fine. Price, 8 cents.

Hydrangea Paniculata. One of the most satisfactory hardy shrubs grown. Immense panicles of white flowers throughout the season. It commences to bloor in July and Japan Quince. Intense flery scarlet flowers in early spring $\begin{gathered}\text { Chinese Wisteria. A grand hardy climbing vine with } \\ \text { clusters of sky blue. locust-like flowers Price, } 20 \text { cents. }\end{gathered}$ Spirea Van Houte. A beautiful variet, NEW CRIMSON SPIREA.

Anthony Waterer. A valuable neV Anthong warieties. $12 \mathrm{cts}$. Mock Orange. (Syringa.) Very popular hardy shrub with Mock Orange. (Syringa.) in greatest profusion $10 \mathrm{cts}$.

single white, fragrant fowers in greatest profusion $10 \mathrm{cts}$. Price, 6 choice varieties, our selection of varieties, for only 50 cents.

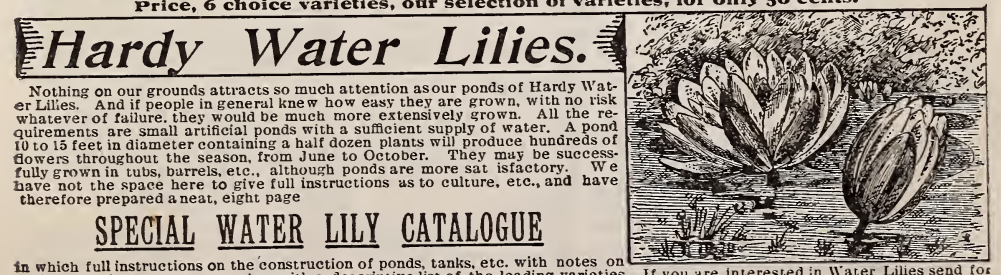

in which full instructions on the construction of ponds, tanks, etc. with notes on their general treatment, together with a descriptive list of the leading voble class of towers.

\section{"गु" Eareka Lazan Mozaler Sharpener.}

Do rou use a Lawn Mow what it is to mow when it is dull, and you also know ho Do you un co get it sharpene. He Eureka will sharpen it. It will save its cheaply and keep it in pertect condition. No matter will last for ten vears. It will sharpen any ordinary dull Mower in 5 minutes. Price, $\$$ r.oo. delivered (charges prepaid) with full instructions for using. 


\section{THE $* N E W * * C A L L A " * B U C K E T *$ SPRAY*PUMP.}

\section{LIGHT, NEAT, COMPACT, STRONG, DURABLE, UNEXCELLED.}

A

BCCKET SPRAY PCMP is a necessity in every garden, orchard, conservatory, greenhouse, poultry house or vineyard for applying the various kinds of insecticides, etc. It is much more convenient and effective than the brass garden syringe, formerly used for this purpose, and is also useful for washing windows, buggies, etc. We have tested the merits and demerits of the difierent pumps on the market, and
have had a special pump manufactured in accordance with our own
instructions, and for our exclusive trade. We believe this pump has
more valuable features than any other pump now on the market. Afthe merits and demerits of the difierent pumps on the market, and
have had a special pump manufactured in accordance with our own
instructions, and for our exclusive trade. We believe this pump has
more valuable features than any other pump now on the market. Af6) the merits and demerits of the difierent pumps on the market, and
have had a special pump manufactured in accordance with our own
instructions, and for our exclusive trade. We believe this pump has
more valuable features than any other pump now on the market. Afthe merits and demerits of the difierent pumps on the market, and
have had a special pump manufactured in accordance with our own
instructions, and for our exclusive trade. We believe this pump has
more valuable features than any other pump now on the market. After using one of these pumps in our own greenhouses continually for over two
years we would not know wherein we could improve it. After using one in your greenhouse you would not do without it for twice its cost. Te have already sold hundreds of these pumps without a single word of complaint. In fact a pump in a neighborhood is almost invariably the means of selling others;

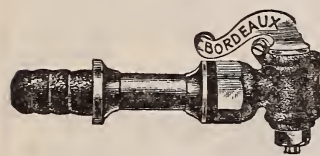
in some instances a half dozen or more.

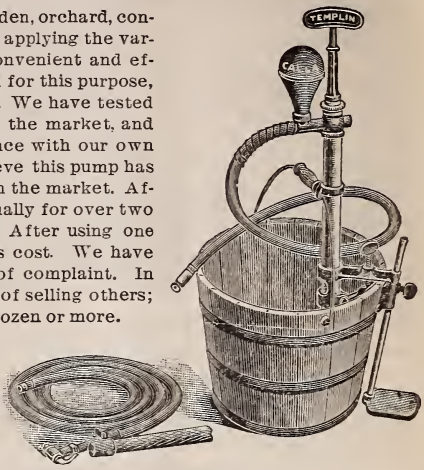

If "U NEED A" Spray Pump you will make no mistake by ordering a "CALLA."
SOME
VALUABLE
FEATURES
खes It is substantially made throughout of the hest material. All working parts being of brass; the bucket clamp, foot rest and handle are marle of malleable iron.
It is donble acting, forcing the water ont with both up ward and down ward strokes. Most Pumps are single acting, forcing the water only with down ward stroke.
OF
THE
"CALLA"
BUCKET
SPRAY
PUMP.
25e It has the largest and most perfect air chamber of any pump on the market, secur- ing a steady stream or spray at all times.
20- It has the most complete adjustable bucket clamp and foot rest, enabling you in a moment to fusten it firmly to a bucket or tub of any size or thickness.
खs It has an extra clamp for holding the bucket hail in an upright position, rendering it easy to move from place to place, always being ready for use.
We It has an agitator which keeps the liquid thoroughly agitated, thus preventing the solution from settling to the bottom of the bucket.
It is furnished with four feet of best quality hose and the improved Bordeaux. Voz- zle, unquestionably the best made, throwing fine spray or solid stream.
It is neat, compact and durable. Manufactured expressly for the florists trade, and is in every way a first-class Spray Pump. There is none better on the market.

The Bordeaux Nozzle.

The only perfect combination nozzle. It will throw fan-shaped spray any fineness, and can be changed to solid stream.

When desired we furnish an extra seven foot hose length and coupling with pole connection for spraying tall trees.

\section{A Fer Unsolicited Testimonials.}

L. Templin \& Sons. Spray ever used. It works to perfection and is very due have Send us two more. I want one for my own use at my home." $\quad$ Very truly, Robert George,

L. Templin \& Sons. Kent, 0 .

Dear Sirs: "The "Calla" sprayer arrived safely and we are delighted witb it. We have sprayed our Plum trees with it, and I find it very useful about the house plants.

L. Templin \& Sons. A. A. Murphy. Oswego. N. Y.

Gentlemen: "I must tell you how pleased I am with the Spray Pump you sent me this spring. It is all $I$ could wish and far better than I expected it to be. I work where a number of men are employed, so the pump was tried and well looked over by several of the men; they all thought it a "dandy." I hope you will have more custom from them."

$$
\text { Respectfully, }
$$

L. Templin \& Sons.

Center Roads, $\mathrm{Pa}$.

Dear Sirs: "Your Spray Pump arrived on the כ̄th, and is highly satisfactory. We can heartily recommend it to any one wishing a Spray Pump."

$$
\text { Yours sincerely, }
$$

C. D. Miller.

L. Templin \& Sons.

Leadville, Colo.

Dear Sirs: "I received the Spray Pump in due season and in fine condition. Am very much pleased with it. It works like a charm.

$$
\text { Very truly, }
$$

L. Templin \& Sons

Mrs. D. Flitner.

Petty, Texas.

Gentlemen: "Spray Pump and plants arrived safe and sound, and I am under many obligations to you for the same. The pump is just what every flower cultivator and poultry raiser needs and cannot be without if he wishes to succeed in his business."

$$
\text { Respectfully, }
$$

Mrs. R. P. Davis.

L. Templin \& Sons. "The "Calla" Bucket Spray Pump is all that you
claim for it." claim for it." $\quad$ Very Truly, C. F. Sauressing.

NOTE. Our price last Season was $\$ 3.00$, but owing to advanced prices on material, we are compelled to advance the price to $\$ 3.50$. Our manufacturers insisted on our listing them at $\$ 4.00$ to conform with their prices on a somewhat similar pump, but our motto is "live and let live."

THE "CALLA" IS THE BEST SPRAY PUMP ON THF MARKET TO-DAY FOR THE PRICE.

Price, complete with four feet of hose and the Improved Bordeaux Nozzle, \$3.50. Seven foot extension hose with pole connection and coupling for spraying trees, $\$ 1.00$ extra. 

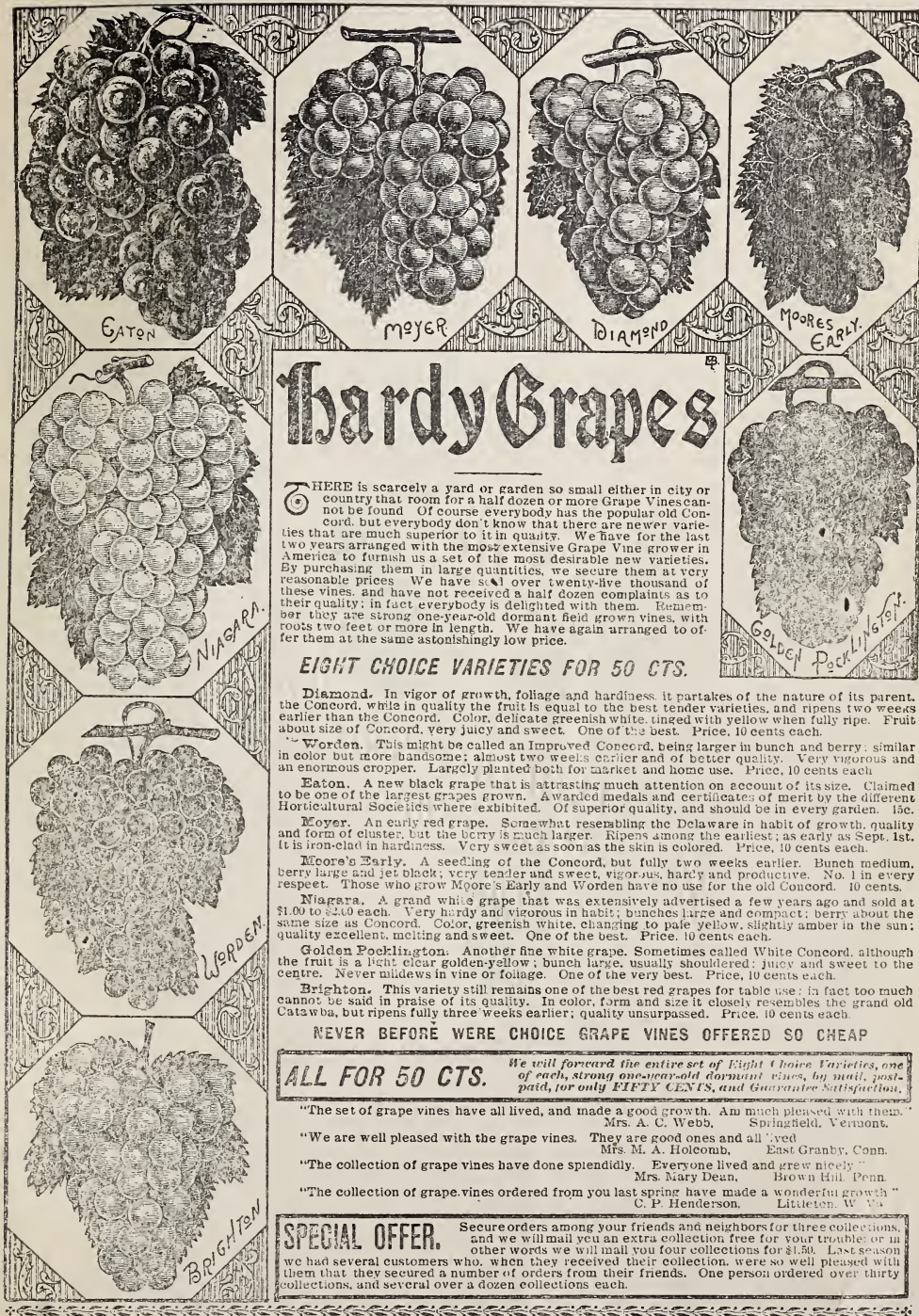

Diamond. In vigor of grow th toliage and hardiness to partales of the nature of its parent. the Concord, while in quality the fruit is equal to the best tender varieties. and ripens two weess Wordon. Tuis might be called an Improved Concord. being larger in bunch and berry similar an enormous cropper. Larpely plunted both for tarket and home use.

Eaton. A rew black grape that is attrasting much attention on account of its size. Claimed
to be one of the largest grajes grown. A warded medals and certificates of merit by the different
Horticultural Societics where exbibited. Of superior quality, and should be in every garden. IJc. and form of cluster. but the bcry is fuch larger. Fipens dmong the earliest; as early as Sept. 1st. Mroore's Msrly. A seeding of the Concord, but fully two weeks earlier. Bunch medium. respeet. Those who grow Moore's Early and Worden bave no use for the old Concord. 10 cents.
Niapara. A grand whice grape that was extensively advertised a few rears ago and sold at $\$ 1.00$ to 2.6 each. Very hirdy and vigorous in habis; bunches liarce and enmpact: berry ibout the
same size us Concord. Co.or, greerish white, clianging to pale yellow, slightly amber in the sun: quality ezcellent. mciting and sweet. Qne of the best. Price. 10 cents each.
Golcton Poclalirgton. Another fine white grape. Sometimes called white Concord, although

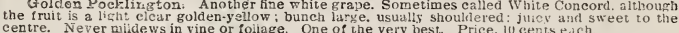
Brizhton. This variety still remains one of the best red zrapes for table tise: in fact too much cannos be said in praise of its quality. In color, form and size it elosely recembles the grand old MEVER BEFOSE WERE CHOICE GRAPE VINES OFFERED SO CHEAP

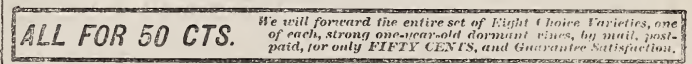
"The se $t$ of grape vines have all lived, and made a good growth. Am n

"We are well pleased with the grape vines. They are good ones and a

"The collection of grape vines have done splendidly. Everyone lived and

"The collection of erape vines ordered from you

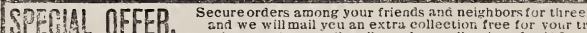
we other words we will uall you four collections for s1.5it. them that they secured a number if orders from their friends. One persoil ondered over thirty

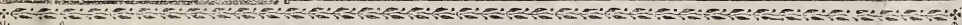

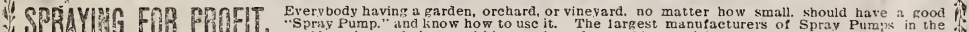

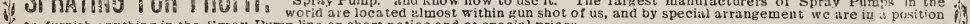
i. to furnish anything in the Spray Pura line on short notice and at special prices.

VI It contains over $\mathbf{0} 00$ puges fully illustrated and deseribing all kinds of Inserts and Fungi pests. together with directions how to 10 if destroy them Formulas for mixing and applying the Bordeatux and many other mixtures: well worth many times its cost. to any4. body interested in the subject of spraying. To any one seriding 20 cts. for a copy. of this book we will return a rebate check kuorl for ho 11 which will be maled with he book and to all others who apply. 


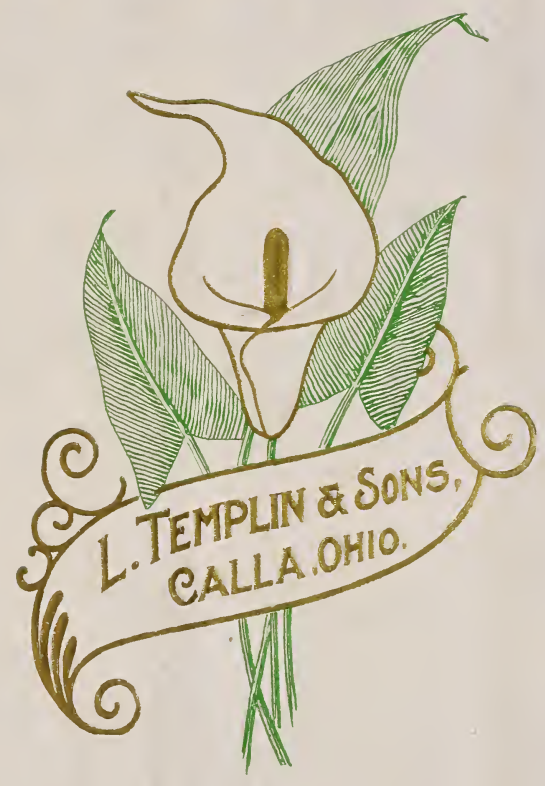

